UC-NRLF

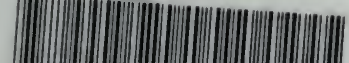

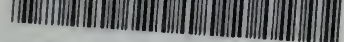

\$B $756 \quad 321$ 


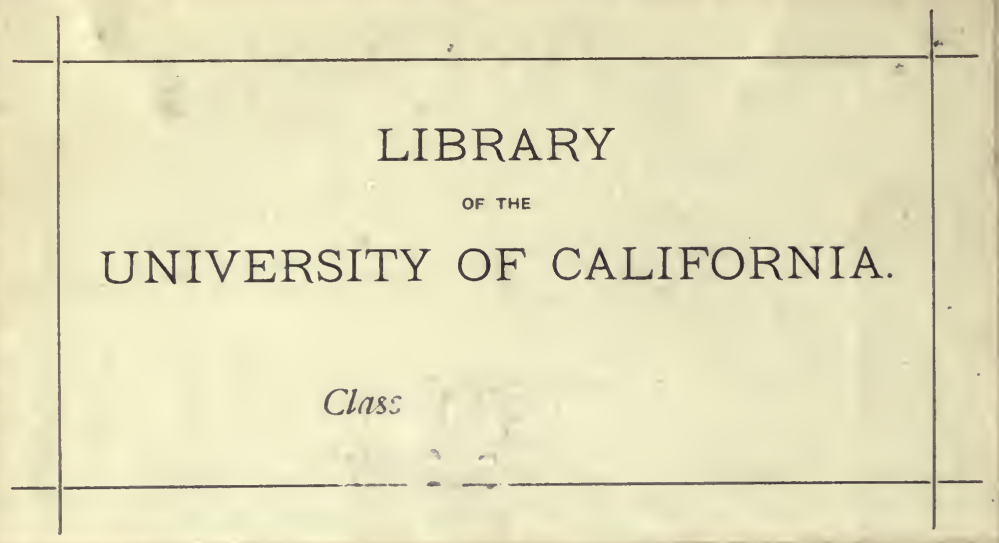

GENERAL 

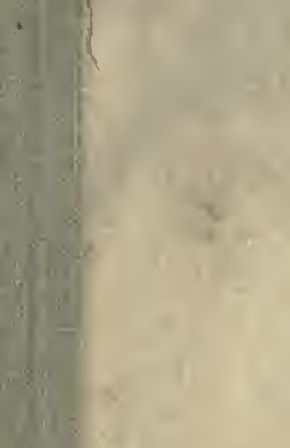

the
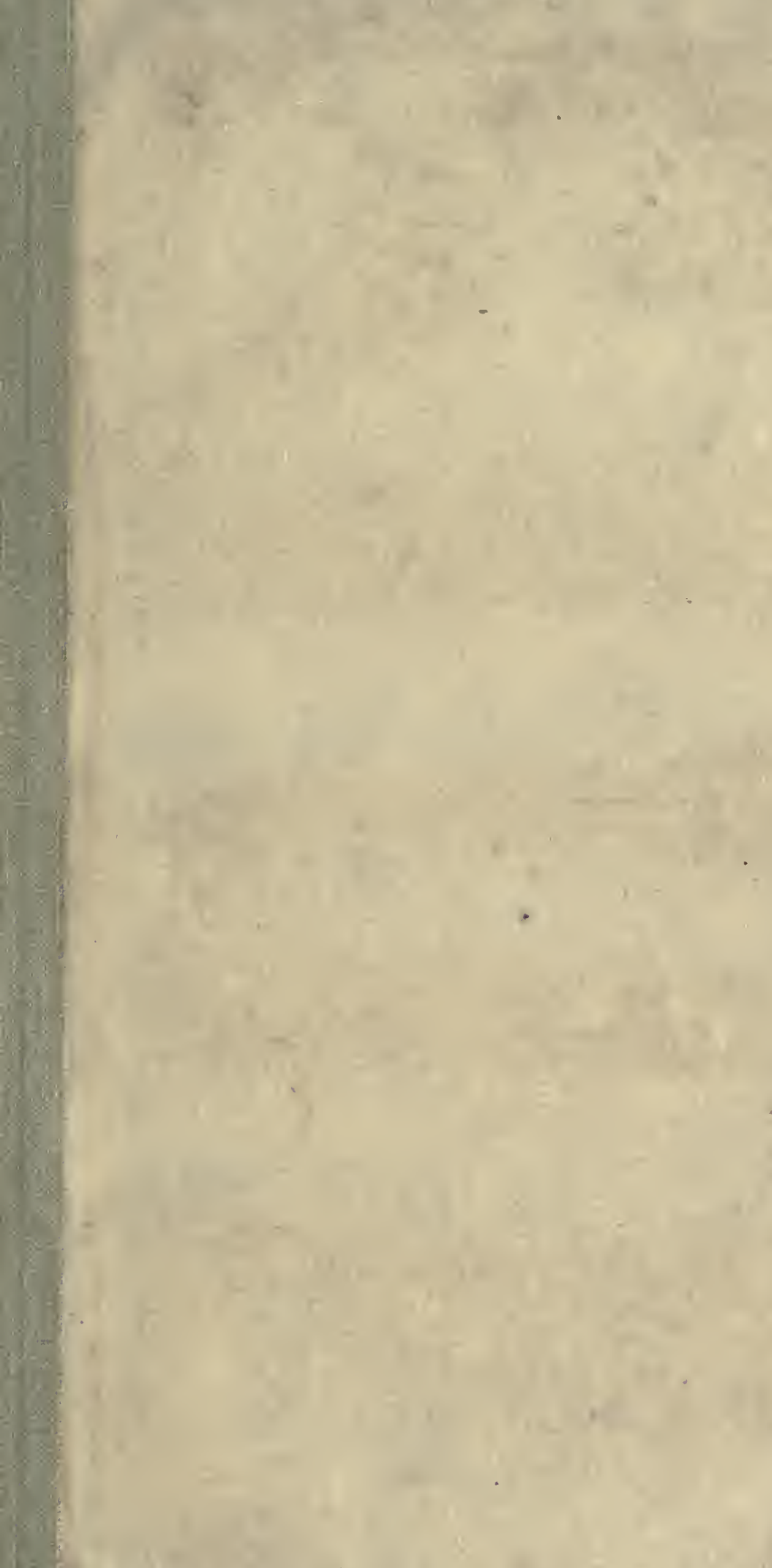

. $7=$
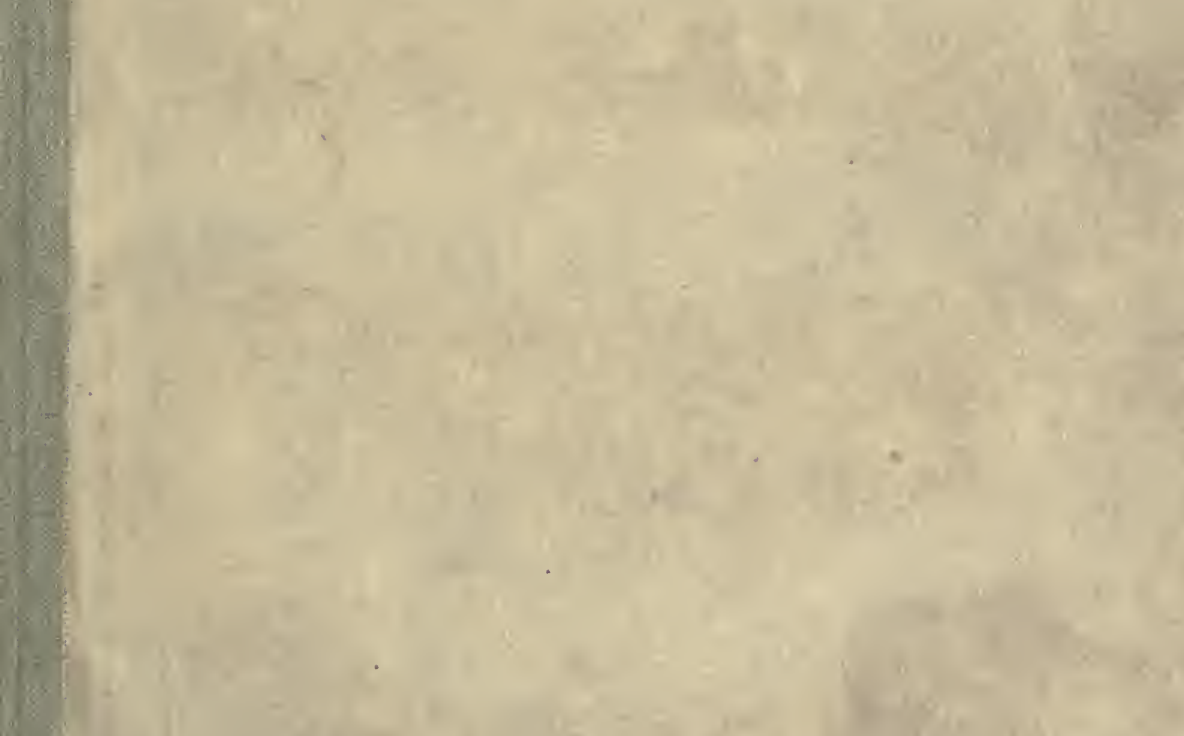


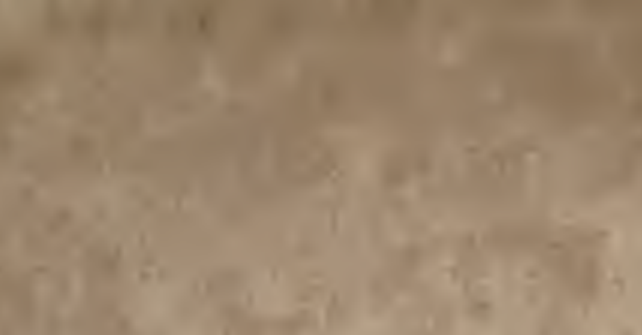

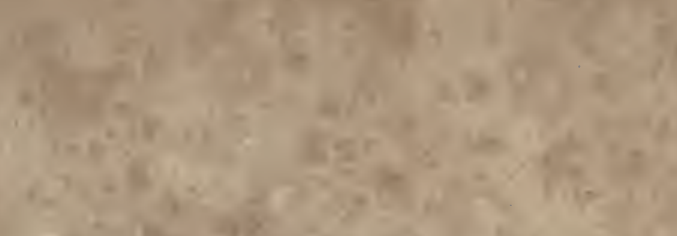

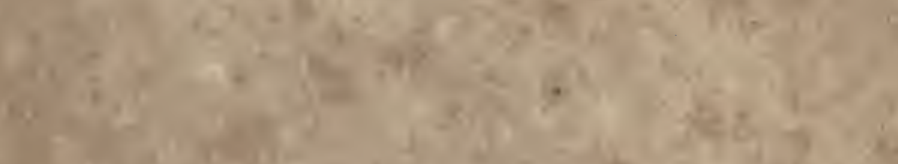

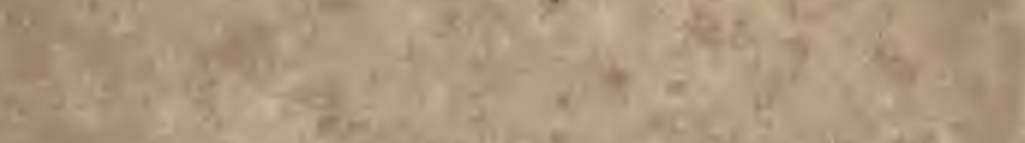

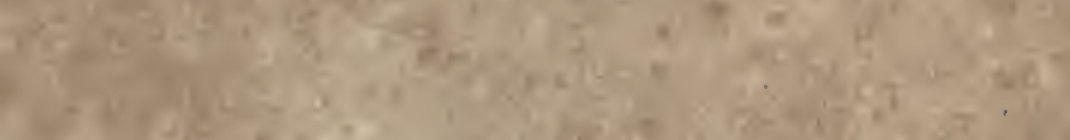

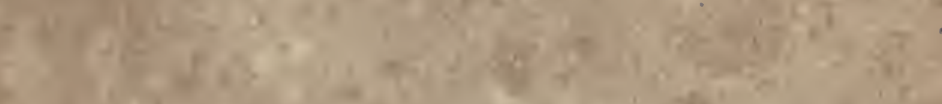

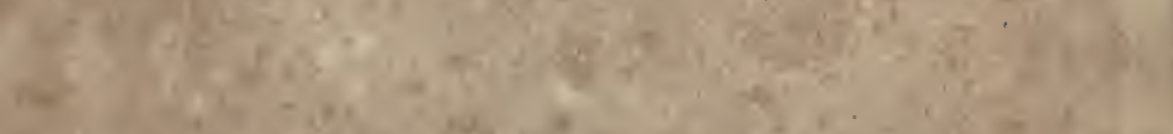

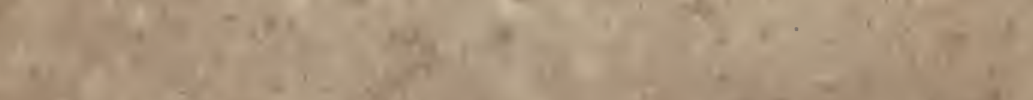

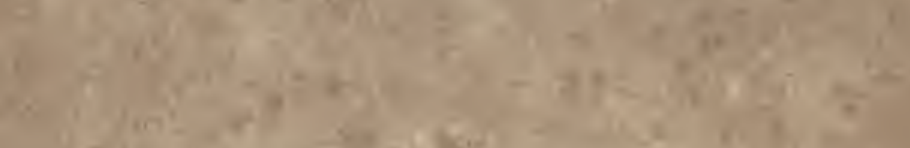

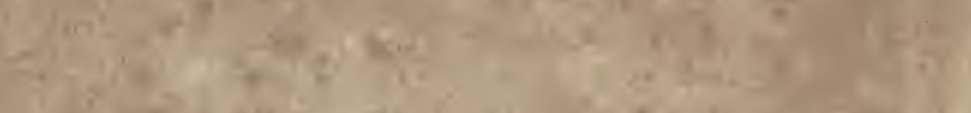

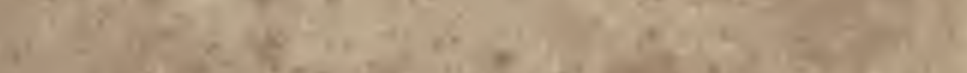

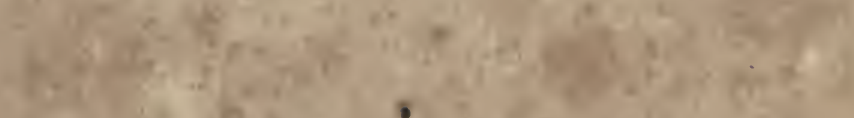
a. whisyis

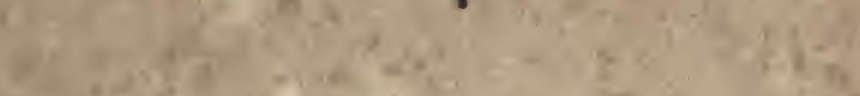

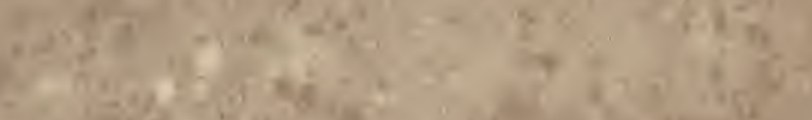

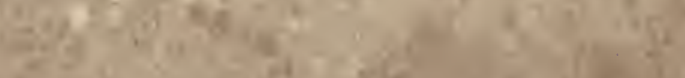
ấ

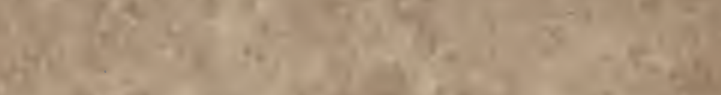
तथ

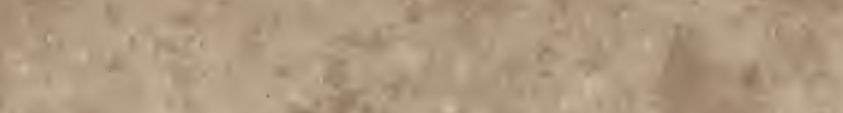

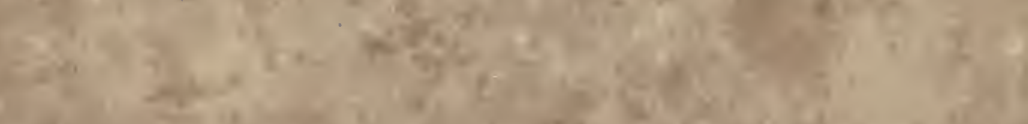

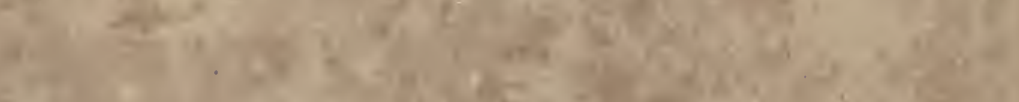

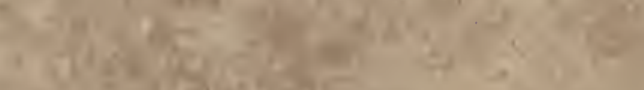

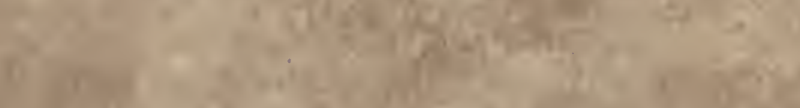

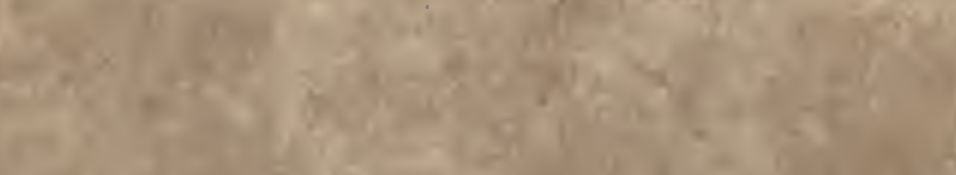
ing 


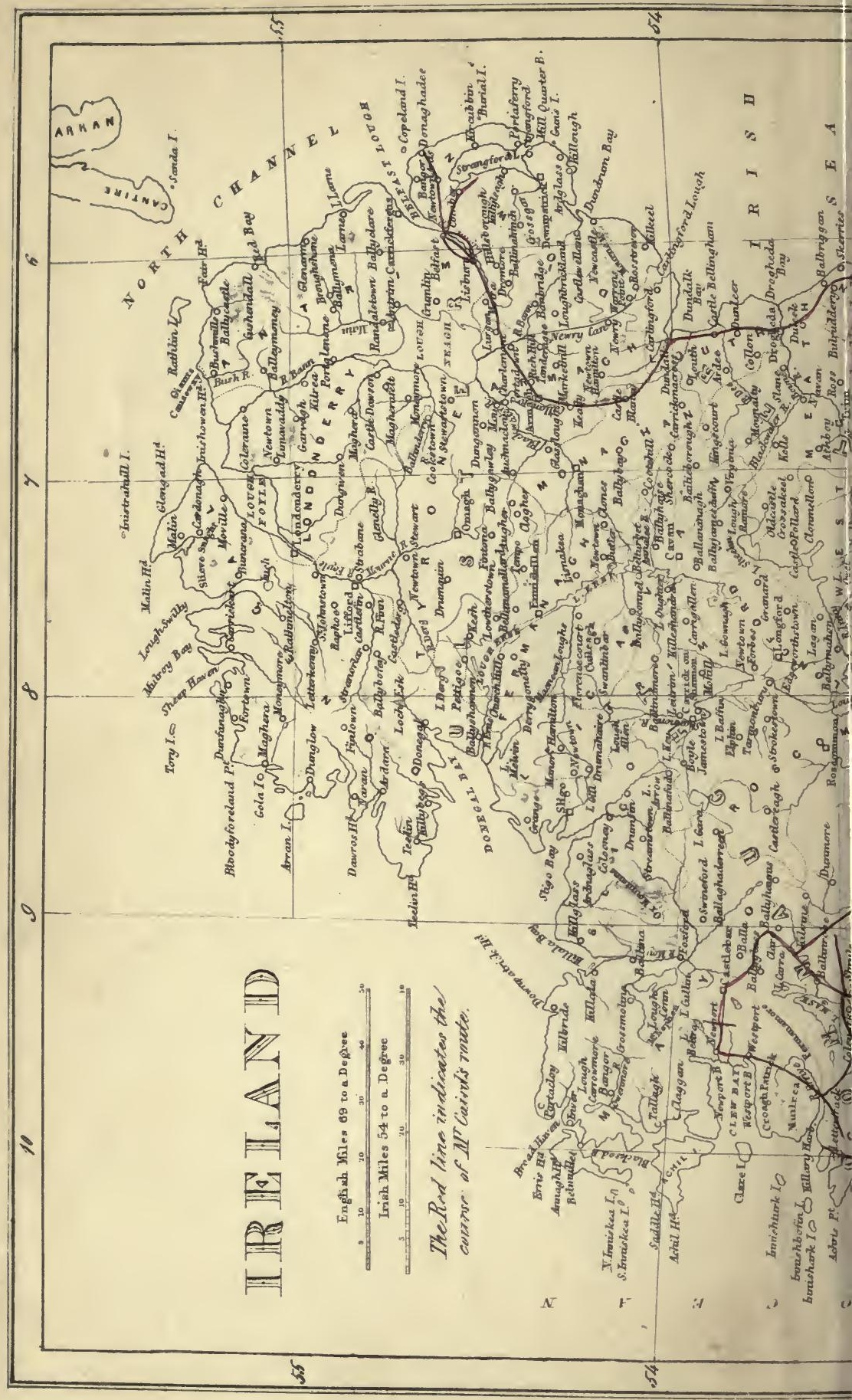




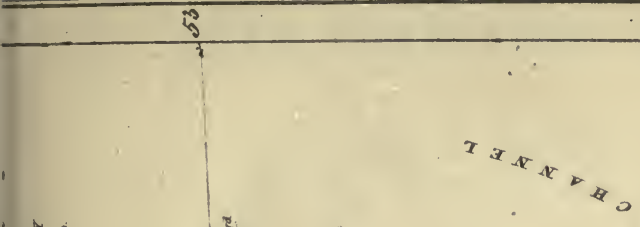

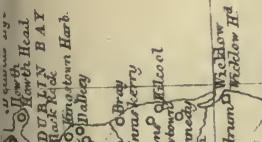

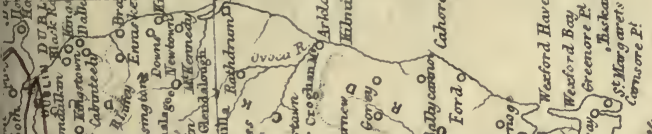

4

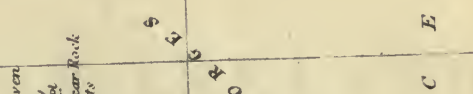

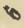

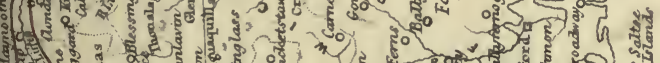

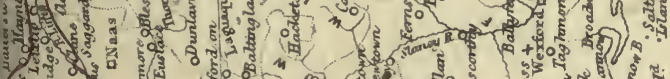
2. 3ै 3 ,

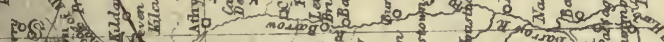

है 3

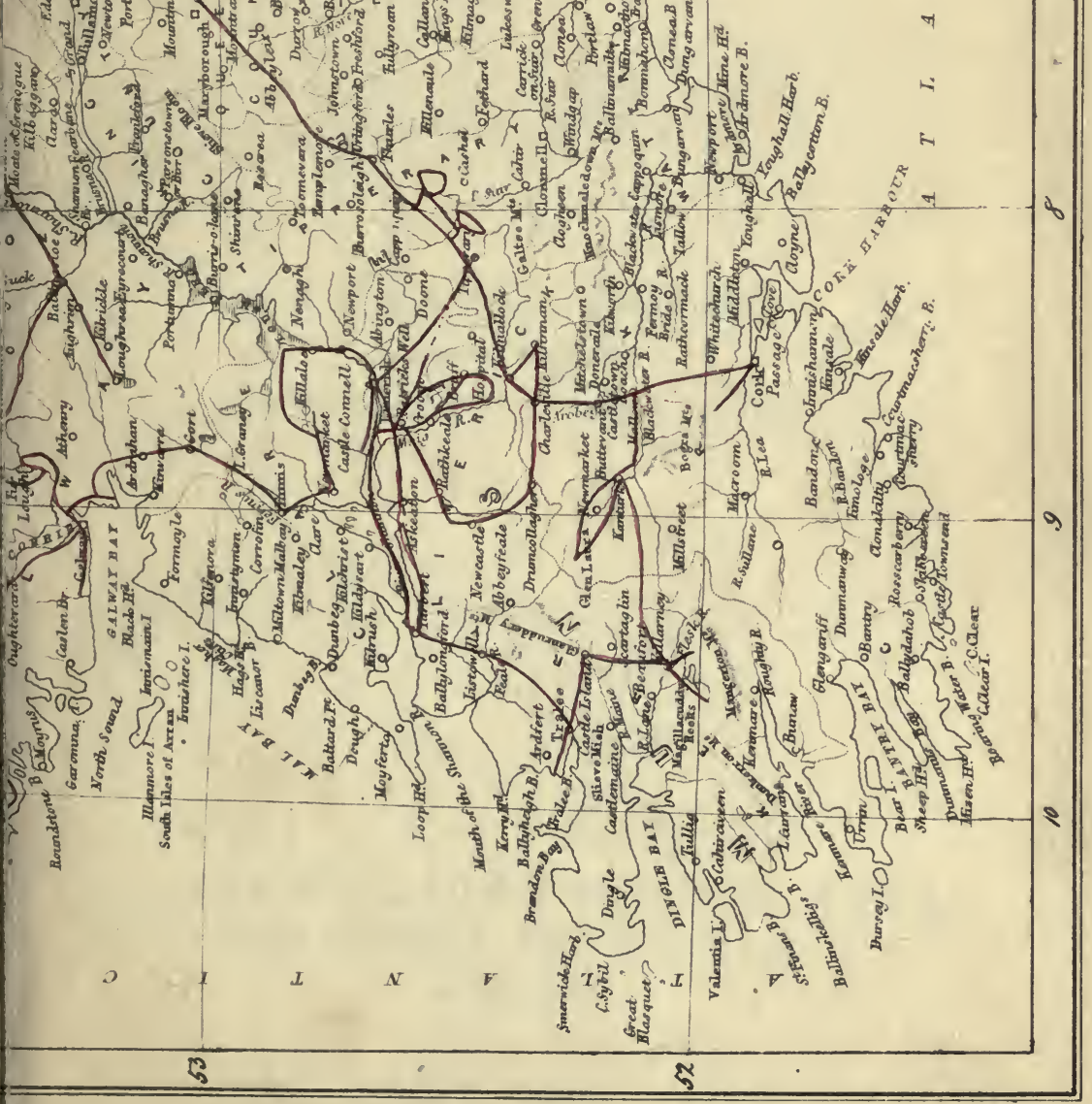

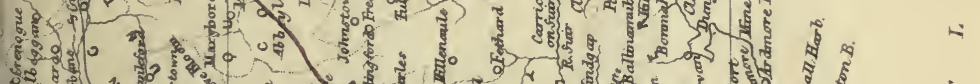

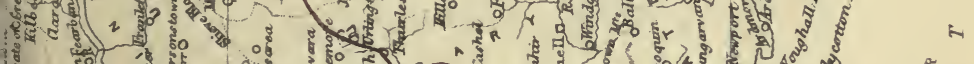


Digitized by the Internet Archive in 2008 with funding from Microsoft Corporation 


\title{
THE PLANTATION SCHEME;
}

\author{
OR,
}

\section{THE WEST OF IRELAND}

\section{A FIELD FOR INVESTMENT.}

\section{BY JAMES C:AIRD, FARMER, BALDOON.}

AUTHOR OF " HIGH FARMING UNDER LIBERAL COVENANTS."

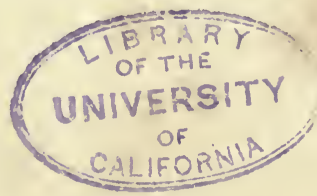

W ILLIAM BLACK WOOD AND SONS, EDINBURGH AND LONDON. MDCCCL. 


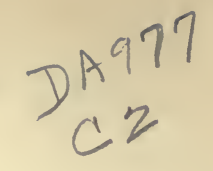

\section{GENERAL}

PRINTED BY WILLIAM BLACKWOOD AND SONS, EDINBURGH. 
THIS VOLUME

IS RESPECTFULLY DEDICATED TO

\section{THE GREAT STATESMAN,}

WHO SACRIFICED POWER,

AND THE REGARD OF FRIENDS,

TO THE SAFETY OF HIS COUNTRY;

AND WHO,

FREE FROM THE RESPONSIBILITIES OF OFFICE,

HAS NOT CEASED TO DEVOTE HIMSELF

TO THE

REGENERATION OF IRELAND. 



\section{CONTENTS.}

PREFACE,

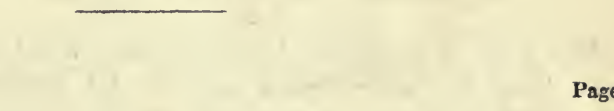

C H A P E R I.

Mullingar-Bogs-Athlone-Ballinasloe-Great annual fair-Garbally - Aughrim to Loughrea-Ballinasloe to Ahascrag-Mount BelewTuam-Peasantry-Winter food for stock-Mr Bianconi, . .

\section{CH A P TER II.}

Hollymount - Mr Lindsay's farms described - "Turloughs" - Lord Lucan's farms-Ballinrobe-Cong-Castlemagarret-Plains of Majo -Castlebar-Lord Lucan's estate and management,

\section{CHA P TER III.}

Castlebar-Union workhouse-Gaol-Charitable relief works-Newport-Sir Richard O'Donnell's estate-Flax cultivation-Courtrais method of steeping-Clew Bay-West Port-Marquis of Sligo's estate-Stock farms-Killery harbour-Kylemore-Maume-Doorus -Clonbruck-Ross-Lord Leitrim's demesne-Ashford-Subterranean river-Canal,

\section{CHAPTER IV.}

Oughterard to Galway-Annagh-Mr Bodkin's farms-TurloughsCarrying off crops-Ballinahinch-“The Martin estate "-ClifdenCleggan-Inlets of the sea-Derrygimlach-Roundstone-Peasantry of Connemara-Taskwork--Description of Martin estate on Lough Corrib-Farmer's house-Break down-Head of the bay of Galway -Ardfry-Mr Skilling's farm-North shore of Galway Bay-Town of Galway, 


\section{HAPTER V.}

Gort-County of Clare-Ennis-River Fergus-"Corcase lands"-

Dromoland Castle-Sir Lucius O'Brien's farms-Bunratty-Course of cropping and average produce-Fall in rents-Kiltanon-Complaints of north country farmers-Pressure of rates driving tenants of capital out of the country-Tulla-Relief roads-Scariff-Lough Derg-Killaloe-The Shannon-Miltown Malbay-Corofin-Kilrush,

\section{CHA PTER VI.}

The city of Limerick-Adare-Croom-East-Lothian farmer-BruffRent of land-People grateful for employment-Limerick to Tarbert by steamer-Tarbert-Mr Blacker's tile and pottery works -Country above Tarbert-Mr Fitzgerald's peat-Glin castle-Foynes -Askeaton-Clarina-Tervoe-View from Carrigogunniel-Rental and price of an estate-Wretched huts, . . . .

\section{CHAPER VII.}

Castleton-Rates-Deserted land-Auxiliary poorhouse-SchoolOne mode of becoming a farmer-Mr Cox's farm-Sir D. Roche's farm, its advantages-Caherass-Adare manor-Rathkeale-Newcastle-Lord Devon's estates-Advantage of a resident agent who understands his business-Beneficial arrangement with tenants, and satisfactory result-Springfield castle-Instance of fertility-Charleville-Castle Oliver-Description of country-Kilmallock to Limerick -Cratloe, . . . . . . . .

\section{CHAPTER VIII.}

Cratloe-Mount Trenchard-Lord Monteagle's estate-Foynes harbour-Model farm-Agrarian outrage-Tarbert to Listowel-Turf traffic-State of the people-Hopes of the landlords-TraleeCastle Island-Mr Herbert's estates-Killarney, . .

\section{CHA P TER IX.}

The Blackwater-Rosnalee-Subletting-Dromagh-King Williamstown -Reclamation of waste lands-Success of the experiment dependent on con-acre labour-Con-acre labour described-Valley of the Blackwater-Mallow to Cork-Mr Jeffryes' farms-Excellent management of stock-Rent of land-"Waste land"-Because deserted-Tipperary-Lord Hawarden's farms-Road sessions-Mr Bianconi-His estate--Lord Stanley's farms-Goolds Cross to Dublin-Glasnevin, 103 


\section{CHAPTER X.}

Reflections-Farmers' investments-Landlords' investments-Obstacle to the latter-Indefinite nature of rates-Comparative state of the country in 1779 and 1849-Arthur Young's tour-Rise of rentsRedundancy of population-Proportion in east compared with west -Dependence on potato-Relief-works unavoidably unproductiveIncrease of grand-jury cess and poor and labour rates-All primarily thrown on the tenant-Abandonment of farms-Necessity of a limitation of rates to encourage immigration of capitalists-Emigration-Variable amount of valuation-Propriety of discouraging conacre-Simplification of sale and transfer of land-Incidence of grand-jury cess unjust to tenant-Advantages of transferring it to landlord-Cure 'for absenteeism-Unexhausted improvementsPopulation of Connaught-Compared with England and ScotlandNecessity for a comprehensive measure, . . . . 121

\section{CHAPTER XI.}

What is now being done for Ireland-Board of Public Works-Roads, piers, arterial drainage, landed property improvement, fisheriesNational schools-Statistical returns of agricultural produce-Agricultural instructors, .

\section{CHAPTER XII.}

Farm-buildings-Economical plan of, described-Estimate and costExtension of Land Improvement Act-Necessity of defining proportions repayable by landlord and tenant respectively-Government loans rendered necessary by incumbrances and entails-Unsound state to which these have led-Free transfer of land the only remedy

-Expediency of Government loans in the mean time,

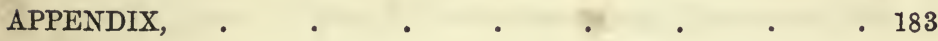

\section{L L USTRATIONS.}

MaP of IRELAND,

Plan of Farm-Buildings,
Frontispiece.

- To face page 171. 
Lately published, price 1s.

With Fngraved Plan of Farm-Buildings,

THE SIXTH EDTTION,

\section{IIIGI FARMING UNDER LIBERAL COVENaNTS,}

\section{THE BEST SUBSTITUTE FOR PROTECTION.}

By JAMES CAIRD, Farmer, Baldoon.

"It must therefore be the interest of all persons connected with land to encourage the extension of the more skilful and improved agriculture described by $\mathbf{M r}$ Caird, and by every means to diffuse the knowledge on which the profitable practice of the system depends." $-E d i n$ burgh Review, Oct. 1849.

"I believe it will be of the greatest possible benefit to the agricultural labourer, by affording increased employment." - Speech of the Chancellor of the Exchequer on the state of the nation, $2 d$ July 1849.

"His facts are invaluable."-Journal of Agriculture. 


\section{PREFACE.}

Among the various projects for the regeneration of Ireland, none has excited so much attention as the Plantation Scheme, developed by Sir Robert Peel. It at once gained the notice of England, and raised the drooping hopes of Ireland, while it also indicated a new and untried field for the enterprise of the capitalist, landlord, and skilled farmer.

At the time of its announcement, the competition for farms in Scotland, and the consequent increase of rent, was progressing to such a degree as materially to lessen the profits of the farmer ; and the development of the Plantation Scheme was, therefore, hailed as possibly an advantageous outlet for our agricultural capital and skill. The success of the scheme would be, in an important degree, secured, if to the philanthropic views of statesmen and great capitalist companies, could be added the narrower, but still equally essential principle, of commercial profit to the men through whom its development was to be practically accomplished.

Inquiry was then made for sources of information whence might be learned the nature of the soil, its capa- 
bilities, its advantages or disadvantages, as compared with this country, and the probable feeling of the population towards immigrant farmers; but on these points the different "tours" in Ireland were altogether deficient. To satisfy himself, the Author resolved to visit the country; and his tour proved so interesting and instructive to him, that he hoped its publication might, in some degree, supply the information wanted.

Before going to Ireland he had an opportunity, through a friend, of mentioning his intention to the distinguished statesman to whom this volume is dedicated. With the utmost readiness, Sir Robert Peel proffered an introduction, which secured access to information which has been of the greatest value to the Author.

His Excellency the Lord Lieutenant of Ireland, ever watchful for the good of the people over whom he has been called to preside, was considerately pleased to countenance the Author's object, and to secure for him many facilities, for which he must ever feel deeply grateful.

To Mr Griffith of the Board of Works he has been also peculiarly indebted for the very valuable aid which his extensive knowledge of the country and its physical capabilities enabled him to afford. 


\section{H A P T E R I.}

MULLINGAR-BOGS-ATHLONE-BALLINASLOE-GREAT ANNUAL FAIR GARBALLY-AUGHRIM TO LOUGHREA-BALLINASLOE TO AHASCRAGMOUNT BELLEW-TUAM-PEASANTRY-WINTER FOOD FOR STOCK-MR BIANCONI.

In the latter end of September, I left Scotland and proceeded through Belfast to the Irish metropolis, whence I at once set out for the western counties of Ireland. Leaving Dublin on 4th October, I proceeded by railway to Mullingar, (50 miles,) thence by car to Athlone and Ballinasloe, (48 miles,) passing through an immense extent of good land, the greater proportion of which is in old grass. The pasture lands are held by extensive grazier's, who, as I was informed, are the only class of large farmers in Ireland, occupying under a landlord, and really possessed of capital. There are many extensive tillage farmers, as I afterwards found, in the west and south of Ireland; but they occupy their own lands, and are of course in a different position from the tenant farmers of England and Scotland.

The line of railway, after passing through the county of Dublin, runs along the borders of Kildare and Meath, and into the centre of West Meath at Mullingar. The line is here unfinished, but the works are going on; and the whole length, from Mullingar to Galway, is expected to be completed in little more than a 
year. The country, all the way from Dublin to Galway, is limestone : it presents a flat and rather uninteresting outline, nowhere rising to any considerable elevation. The richest parts between Dublin and Mullingar (fifty miles) seemed thinly peopled. But after passing Kilcock station, some twenty miles from Dublin, the railway skirts a portion of the Bog of Allen; and here were congregated a great number of huts, and squalid miserable-looking people. These huts were simply sheds leaning against the face or "breast" of the bog, the walls formed of sods of turf, and the roof covered with sods and rushes, evidently quite unfit to exclude rain. One hut seemed to be just a cave cut out of the deep bog. The wretched people appeared to have located themselves without hindrance, getting no resting-place on the richer land, and swept off here to shift for themselves, as the nearest waste place for such a nuisance to be allowed to stagnate. As the train passed, great numbers of the denizens came running out to see it. One boy, about ten, rushed to a door, perfectly naked, gazing at us quite unconscious of his own strange appearance. Savage enough it looked, as seen from a most luxuriously fitted railway carriage, and within a few miles of the city of Dublin.

The hay crop (from the natural grasses) was almost all in the field, a fine crop. Patches of grain were still in shock, more in rickles in the field, and where stacked it was still unthatched. This seems a point in which Irish farmers are very careless. Almost everywhere I observed unthatched stacks, much injured by rain.

We crossed several extensive bogs-rich black moss, 
such as we consider in Scotland most improvable, and situated at a very moderate elevation above sea-level. They are usually the lowest parts of the country, yet generally susceptible of drainage ; the gravelly land surrounding them sloping gently up, and affording abundance of limestone sand, and gravel, for mixing with and reclaiming them. Where traversed by this line of railway, they might be turned to good account, as they possess great natural facilities for reclamation, and ready access to market at Dublin, which may be reached in an hour or two. The country all along presents a continuous slightly undulating surface, but no elevation of any consequence, and little wood except in the demesnes of the gentry.

At Mullingar it was market-day, and the streets were crowded with country people, all of whom seem to have a natural taste for dealing and attending fairs. Donkeys, and small, ill-fed horses, yoked to very primitive low-set carts, or simply with panniers, seemed the general mode of conveyance. Poultry, of which geese formed a large proportion, occupied the panniers. Garden regetables, pigs, sometimes a kit of butter, and frequently the mistress of the household, occupied the cart. A strapping "boy" led the horse, and the father of the establishment stood behind, ready to transact business with a purchaser. The streets were dirty, and there was no sign of much comfort about the houses or inhabitants of Mullingar.

A few miles farther west the land is very fine; and nearly all the way to Athlone, thirty-one miles, you pass continuous fields of the finest feeding land. On all sides, 
as far as the eye can reach, this seems the character of Westmeath. There are many roofless houses on the roadside, the inhabitants of which have been ejected. The patches of tilled land around these houses generally exhibit unmistakeable signs of the most wretched mismanagement. The people employed in the fields seemed everywhere to take things easy. All the reapers had on that apparently indispensable garment, a long-tailed frieze-coat, and they certainly did not look as if their work would keep them warm without it. In haymaking, a good deal of which was going on, the men all worked with the coat on; indeed, I did not see a man at fieldwork of any kind without it. Who ever saw a harvestfield in Scotland, or a hay-field, with the men working in long-tailed coats? There, an Irishman strips to his work in harvest, and does it well. Here, the froglike appearance of the men, with the tails of their coats jerking behind them, as they bend to their work, presents a striking contrast to the conduct of the same men when on the other side of the Channel, under proper superintendence, and with the stimulus of good wages.

Athlone is a good town on the Shannon, a little below Loughrea. The navigation from the sea at Limerick by canal, loughs, and river, is nearly ready to be opened. But the more direct communication by railway, on the completion of the line from Dublin to Galway, on which this town will form a principal station, will render this inland navigation of secondary importance.

Crossing the Shannon, we enter Connaught, proceeding through part of the county of Roscommon, fourteen miles, to Ballinasloe. The country here is inferior 
and uninteresting. At Ballinasloe we enter the county of Galway.

I was fortunate in arriving here during the week of the great annual fair. Vast droves of fine sheep, which had been sold early in the day, were already some miles on the road from the market, rendering it almost impassable. Within three or four miles of the town, every hut on the road-side had its table at the door, with a few loaves and apples to sell to the wayfarers. The wife and children presided at this table; and here and there the lusty patriarch of the household might be seen with his arms crossed and the pipe in his mouth, lounging at the door, and indolently superintending the establishment. Where there was no house, the rudest possible imitation of a tent was made to cover the table, though in many cases even this was dispensed with. These refectories were stationed every three hundred yards or so along the road. Now and then they presented, besides the bread and apples, a bottle of potheen and a glass; and at one, provided with more than usual care, two plates of large boiled eels graced the board. Nearer the fair, a party, consisting apparently of a father and five children, were seated in a row on the footpath, naked-like and miserable, and all screeching out for charity as the different cars passed by.

The fair at Ballinasloe lasts about a week, beginning with sheep, then horses, and ending with cattle. The stock of the western counties are disposed of at this fair, and generally bought by the great graziers of the eastern and midland counties, to be fattened on their rich pas- 
tures, and passed on to Dublin or the English market. The supply of sheep this year was little over sixty thousand, being a deficiency of from ten to twenty thousand as compared with former years. This is accounted for by the quantity of "waste land" in the western counties; that is, land which has fallen into the landlords' hands, and is unoccupied and unstocked. It is also alleged that many graziers were obliged to stock their lands with cattle instead of sheep, on account of the difficulty of preventing sheep-stealing in the more distressed districts, while the very numbers stolen decreased the usual supply.* The sheep were generally splendid, the best three-year-old wethers selling at upwards of 50s. each. The sheep fair is held in Lord Clancarty's park at Garbally, where the immense droves grouped about among the trees, and along the undulating slopes, the cries of the shepherds and the barking of their dogs, the shifting figures of buyers and sellers moving about the field, all formed a very striking and animated scene.

Horses were not reckoned as good a show as usual, but there were very many fine horses both for saddle and harness.

The supply of cattle was as much on the increase as that of sheep was deficient. They were mostly crosses,

* The decrease of the sheep stock is a notable fact, and is corroborated amply by the constabulary returns of agricultural produce for 1847 and 1848 , by which it appears that

The total numbers of sheep in Connaught, for 1847 , were 595,737

Do.

do.

1848 ,

471,205

Decrease,

or one-fourth part of the whole stock in the province.

124,532 
some with the short-horn, some with the Hereford, and some with the Ayrshire breeds. Generally they were prime cattle, and in fine condition for fattening. off either on pasture or in the stall.

Ballinasloe seems a very thriving town. The houses are good, and the churches and other public buildings handsome and substantial. It must be much benefited by the influx of people attending the fairs, and it has also the advantage of a careful resident landlord, the Earl of Clancarty.

At Garbally, his lordship's residence, I met Lords Howth, Monk, Dunsandle, the Bishop of Tuam, and several other gentlemen; all of whom seemed much interested in farming, and possessed of a good practical knowledge of it. Lord Clancarty mentioned the case of one of his tenants, holding 20 acres, who, notwithstanding the times, managed, by house-feeding and green crops, to dower his daughters handsomely, besides fulfilling all his other engagements.

From Ballinasloe to Aughrim, six miles, after passing Lord Clancarty's demesne, the land is thin and poor. Beyond that to Loughrea, fourteen miles, it becomes very fine, mostly in grass, and much of it in need of draining. The crops of thistles on the pastures are most luxuriant, and flourish undisturbed. Having viewed the country in this direction, I returned to Ballinasloe, and left next morning for Hollymount by Bianconi's four-horse car.

Shortly after leaving the town, the road passes through an extensive bog, beyond which the first village reached is Ahascrag, where the appearance of a man in authority, clothed in blue, with sundry stripes of red braid on his 
cap, arms, and trousers, attracted our notice. To an inquiry from a gentleman on the car, he replied that he was the bailiff of a landed proprietor, who employed also five or six others, at 13s. a-week during harvest; and that their business was to prevent the tenants carrying off their crops, when cut, to evade payment of rent. When asked if, on such a duty, he was not afraid of being shot, he told us, with a knowing look, that there was no fear of that, for their employer had taken care to select them as being the worst characters in the population. Whether this was a joke or not, it certainly is a queer relation in which the landlord and his tenants stand, with such intermediate agents as these.

At Mount Bellew, the road is very picturesque; the village, with a finely wooded stream issuing from the demesne in which the house and lawns are seen through the trees; the rich hedge-rows, which are here intermingled with ivy and wild-flowers, and remind one of the luxuriance of a Devonshire lane; all contribute to form a very pleasing picture.

From this to Tuam the land is light, but some of it good sheep pasture. Many people were busy at haymaking. In the immediate neighbourhood of the town of Tuam, on the demesne of the bishop, the land was well farmed; fine fields of Swedish turnips and clover indicating superior management. The Roman Catholic cathedral forms a prominent object. It was market-day, and the streets densely crowded by men and women, horses and carts, sacks of corn and other agricultural produce exposed for sale. After changing 
horses, we proceeded on to Hollymount. The fields along the road were usually very well fenced with stone walls, "dashed" with lime, and with a stone and lime coping, substantial, and many of them new. Building walls of this kind is included in the objects for which Government loans, under the Land Improvement Act, are made to the owners of land.

The appearance of the peasantry always attracts the stranger's notice. Whatever they were doing, as soon as the car came in sight all eyes were turned to it. The boy on the cart, pitching up sheares to the stack, sat himself down till we passed; the man on the stack thrust his hands into his pockets, to keep them from catching cold while he was looking at us. The haymakers were all on the watch.-Three carts were in a field being loaded with corn. Two were loaded; on the third, a man was building the sheaves, while a young boy was carrying them to the cart, and then throwing them up with his hand, (for they seem to have no forks,) while two men were close by leaning against the loaded carts, but offering no assistance to the boy, who had the hardest work of the party. Some of the cottages on the road-side looked very neat; but in these you could notice the pig coming out and in at the door, evidently on the most friendly terms with the inmates. "Arrah," as Paddy says, "an' who has a better right? Sure, isn't it he that pays the rint?"

On the grazing farms, the method of providing the winter food seems to be this. Certain fields are shut up for hay. When it is made, it is built in very large round ricks, a pole being first fixed in the ground, 
round which as a centre the hay is built. The rick is then encircled with a paling, 12 feet or so distant from it all round. The paling is open below, so as to admit sheep but not cattle. The field is then shut up from stock, that there may be a good aftergrowth. At the fall of the season the sheep and young cattle are admitted to these fields. When the weather is serere, the sheep go through the paling to eat the hay, at the same time pulling out much more than they eat. The shepherd throws this over to the young cattle. As the sheep eat into the bottom of the rick, it gradually slides down the pole which keeps it all together. The whole plan is economical and ingenious. One rick, with the aftergrowth of grass, generally affords food for 200 sheep and 10 young cattle. In some cases, the meadow land round the rick is too soft for cattle, or might be injured by their feet in winter. When this is the case, the cattle are kept outside of the field within which the hay is stacked, the sheep getting access to it by the sheep-holes in the walls. The shepherd then carries the hay for the cattle to the outside of the wall, laying it down for them at the most sheltered part.

On my way from Ballinasloe to Hollymount, I had the good fortune to travel with Mr Bianconi. He was coming down to start a new coach for the convenience of "his friends the public," and complained loudly of the Postmaster-general for giving the mail contract to a party who was to carry it with a car and two horses, for $9 \mathrm{~d}$ a-mile, when he offered to put on a coach and four, and carry the mail-guard free, for 10d. a-mile. "You don't understand us in England," he said; "that 
is the way you treat men of capital and enterprise, who are ready to embark both if they get the least encouragement. For 1d. a-mile the Postmaster-general sacrificed the protection such a coach would have given to the mails, besides the better accommodation that would have been afforded by it to the public. And here am I, at a moment's notice, with 150 horses thrown idle on my hands." Perhaps the Postmaster-general, as usual in such cases, would have given a different version of the story. Mr Bianconi was buying hay, of excellent quality, at 18 s. to 20 s. a-ton. 


\section{CH A P T E R I I.}

HOLLYMOUNT-MR LINDSAY'S FARMS DESCRIBED-"TURLOUGHS"—LORD LUCAN'S FARMS-BALLINROBE-CONG-CASTLEMAGARRET-PLAINS OF MAYO-CASTLEBAR-LORD LUCAN'S ESTATE AND MANAGEMENT.

Arriving at Hollymount on the evening of the 6th October, I had just light enough to see that this was a very clean, well-built village, adjoining the demesne of $\mathrm{Mr}$ Spencer Lindsay, whose hospitable mansion was my headquarters for the next three days. The park and grounds, intersected by the river Robe, to which on both sides the rich pastures slope gently down-the stream itself ornamented by the overhanging branches of the trees, fine groups of which are also scattered throughout the demesne, under the shelter of whose spreading branches fat lazy sheep and cows were browsing-with the spacious and comfortable mansion on one hand, and the spire of the parish church in the midst of a group of trees on the other, form quite an English scene. Mr Lindsay's gardens are very extensive and productive, but the dahlias and heliotropes had been completely cut down by the sharp frost of the two previous mornings. The church is a handsome building fitted up with square seats of oak, and heated by a stove. The congregation might number from 50 to 60 . 
The service was conducted with great solemnity and decorum, and an excellent practical discourse delivered by the clergyman. An offertory was collected and laid on the altar.

On Monday, I was joined by Mr Elwood, inspector of drainage for Mayo, with whom I accompanied $\mathrm{Mr}$ Lindsay in a long ride through the neighbouring country. We first visited the farm of Layhinch, adjoining the demesne of Hollymount. It is almost all in old pasture, well fenced, and beautifully sheltered with fine ornamental timber. It is rich dry hazelly land, admirably suited for sheep, intersected by good roads, and in excellent condition. A farm of 400 acres of prime land could be had here. Mr Lindsay would build the necessary farmhouse and steading for a tenant of capital.

We next rode to Kilrush, close to the village of Hollymount, where another farm of 400 acres or so might be had. The greater part of this farm is good feeding land, long in grass; part of it reclaimed bog, lying on limestone gravel ; and part good dry land, lately laid to grass. A set of buildings for an agricultural school was some years ago erected here, but that object having been abandoned, they have now become the farm-steading. The proprietor would add what may be necessary, do such farther draining as may be required, and let the farm on a 19 or 21 years' lease, taking upon himself all rates and burdens whatsoever, and giving the farm at 25s. per English acre. For land of such quality, fenced in a way that we have no notion of in Scotland, 
(with five feet stone-and-lime walls,) with abundance of lime and limestone gravel beneath the surface, and plenty of turf to burn it, with a convenient homestead in a good neighbourhood, and the high-road to Dublin as one of its boundaries, such a farm would be taken up at once at this rent in Scotland.

We next rode to Greyhans, some miles farther south, where there is an excellent dwelling-house, garden, and most substantial buildings, in good order; and where one farm of 1000 acres, or two farms of from 400 to 600 acres, may be had. This land is well enclosed, but it is more various in quality than either of the former. One kind of it may consist of the finest feeding land, old grass; the rest is land of good quality, but in wretched condition, having been held on the conacre* system, and much exhausted; a portion consists of "Turloughs" or low grounds, flooded in winter, but good cattle-pasture in summer, though not sound for sheep. These "Turloughs" are all expected to be laid permanently dry by the arterial drainage operations now going on. In some places the soil lies on cavernous limestone; and when the rivers are flooded by heavy rains, the water spreads through these hollow underground passages, bursting up here and there to the surface, in a powerful stream sufficient to turn a mill, and then at some lower point disappearing as mysteriously as it arose. Where these outbursts take place, "Turloughs" are formed. The whole of this farm is capable of very great improvement, and will

* For a description of con-acre, see Chap. Ix. 
yet, I have not a doubt, prove an excellent investment to some tenant of skill and capital.

The next farm we visited was Frenchbrook, within three miles of the upper end of Lough Corrib. It adjoins the hamlet of Kilmain, where there is a church and chapel, and contains about 500 acres. There is no wood here, but the stone-walls are even more than usually substantial and good. The greater part of this farm is the finest feeding land for sheep and cattledry, friable, undulating land, all on limestone. The fields of rich old grass are superior to anything we have, except in small patches, in any part of Scotland I at present remember. The best of it is too good for tillage, but about one half of it might be profitably brought under the plough. The sheep and cattle then grazing on it were excellent. This is a very desirable farm, though the neighbourhood did not appear so inviting as in any of those which I had previously visited. The proprietor would erect all necessary buildings; and, as there are none at present, these could be constructed on the most approved plan. The present rent paid for this farm by an extensive grazier, an excellent tenant, is not more than 25s. per Irish acre, the owner paying all rates of every kind.

These farms all lie upon limestone, with access to "turf." They are twenty to twenty-eight miles from Oranmore, the nearest station on the Dublin and Galway railway; which station, when the line is opened, may be five hours' ride to Dublin. They are likewise within from three to ten miles from Lough Corrib, 
which in two years is expected to be navigable by steamers from Galway and the sea, some thirty miles distant. Their height above sea-level does not at any point exceed 150 feet. The winters are mild, and the climate most suitable for grass and green crops; the soil is in every way adapted for feeding off green crops if desirable, or for finishing sheep and cattle for the fat market. The milk and butter are of the richest quality. Labourers' wages are at present from $8 \mathrm{~d}$. to 10d. a-day, - the people most peaceable, and very intelligent, though negligent and idle to an uncommon degree, if not carefully superintended. Land may be dug over by contract, 12 inches deep, all the large stones laid on the surface, and the whole placed in fine state for further operations, for about $£ 1$ per English acre. Lime can be burned on every farm at from 5 d. to $6 \mathrm{~d}$. a barrel, of 3 imperial bushels. The rapidity with which the land on this limestone subsoil recovers itself, and, without any seeds being sown, reverts to good pasture, is very remarkable. I saw one instance here of a field exhausted to the last degree, as I was assured, by the con-acre system,which had been abandoned to nature not more than five years ago, and it is now covered with a rich sward of grass.

After passing Frenchbrook we skirted a "turlough," laid dry by arterial drainage, the whole subsoil of which, several feet thick, was rich shell marl. This marl is used with great success, though in a limited degree to what it might be, by the neighbouring cottier-farmers, 
whose comfortable circumstances, during all the famine, can be attributed only to the good crops of grain which the application of this substance enabled them to grow without any other expense. It is a most valuable deposit.-A little farther on, the country is covered with masses of limestone, extending to the borders of the county of Galway, (between Loughs Corrib and Mask,) which are so thickly studded as altogether to put a stop to the labours of the husbandman. Much of this tract might be profitably planted with oak or larch, which would at the same time enhance, by shelter, the value of the pastures intermingled with it.

Some of the soil over which we rode to-day from Hollymount, proved, when turned up by the spade, of uniform appearance for 18 inches in depth, beneath which was limestone, sand, and gravel. It reminded me of the deep black loam on the braes of the Carse of Gowrie, which, however, wants the limestone substratum. Other parts were a reddish, and what is here considered a richer soil -deep friable land, suitable for all kinds of crops.

Next day we examined the farms of Cloonagashel and Gallowshill, a portion of Lord Lucan's estate, in the neighbourhood of Ballinrobe. A considerable part of both these farms, which are nearly 2000 acres in extent, is under tillage; nearly all of it divided into regular enclosures, with excellent stone-and-lime walls. The soil consists partly of a fertile black mould, of great depth, on a limestone gravel, with some stronger land and some lighter, but all admirably adapted for green 
crops and grass; and from the level nature of the ground, and its gentle slopes to the sun, well suited for tillage. There are two farm-steadings, lately constructed, with threshing machinery, \&c. Two or three farms, of from 700 to 1000 acres of land, could be got here, as good land as the average of East Lothian, at a rent of $18 \mathrm{~s}$. the imperial acre, and the poor-rate guaranteed not to exceed 1 s. per $£ 1$. The tenant must also pay the grand-jury cess; but Lord Lucan hands his farms over to his tenants with every permanent improvement executed - so that the farmer may have nothing to do but to stock and work his farm. Wheat and barley are grown on both farms, and lime is to be got on the land at from $5 \mathrm{~d}$. to $6 \mathrm{~d}$. a barrel, and has been applied with excellent effect.

These farms are within a mile or two of Ballinrobe -a market-town, at which a canal from Lough Mask is now being constructed, which, in connexion with Lough Corrib, will give a water-carriage to Galway.

From Ballinrobe to near Cong, the country is bare and uninteresting. In the neighbourhood of Cong the soil and climate improve; and when Lough Corrib and the distant mountains of Connemara open on the view, the scene becomes very beautiful. Cong is a small market-town, beautifully situated at the head of Lough Corrib. The principal feature in it is the ivy-covered ruins of an ancient abbey, and three powerful corn-mills turned by the waters of Lough Mask, which here burst out of the bowels of the earth in a mass as broad as the Thames at Richmond, and as clear as crystal. The 
overflow of Lough Mask disappears through a subterranean passage in the cavernous limestone, from which, after flowing underground for upwards of two miles, it is discharged at Cong. The situation of this little town, with its old ivied abbey, near to the walls of which flows this beautiful crystal river, expanding as it goes into an arm of Lough Corrib, with the wooded demesne of Ashford on the opposite bank of the stream, and the setting sun casting its golden light over the mountains of Connemara, is strikingly picturesque. This is likely to become a farourite resort, when steamers ply on Lough Corrib from Galway, which they are expected to do in the course of a year or two. The climate is very mild. Wheat of fine quality is produced here, and myrtles flourish in the open air.

On the morning of 10th October, accompanied by Mr Elwood, I left Hollymount on my way to Castlebar, passing near Lord Oranmore's at Castlemagarret, a fine wooded demesne of 900 acres, all in grass. We visited the estate of General Sir Robert Arbuthnot, who is carrying out a judicious system of improvement by draining and green crops. After calling at the residence of Mr Lambert, a neighbouring proprietor and extensive stock farmer, we came on through a somewhat elevated district for a mile or two, when, again descending to a lower level, we soon reached the plains of Mayo. These extend for some miles, and are fine gently sloping lands, with no impediment to husbandry, but everything to encourage exertion. In some places they are still untouched by the plough, in others they have gone 
through the usual course of con-acre. It is not easy to imagine a situation more enticing to an extensive green-crop farmer than these plains present. After passing them, the soil becomes inferior. The slope of the country has now fallen to the west and north, and the climate is more serere with this change of aspect.

Around Castlebar, Lord Lucan is taking all the land into his own hands. I walked over great part of his farms, and found them well managed, and all the permanent improvements, draining and fencing (which are done under the Land Improvement Act) being executed with great care and skill. He has built a new and very handsome and commodious farm-steading here, with threshing-mill, flax-scutching apparatus, bone-crushing machinery, \&c. His green crops were excellent; but there is great difficulty in safely harvesting grain crops, or even in extirpating weeds among the green crops, on account of the long-continued wet weather, so frequently experienced here in July and August. A dairy of upwards of 100 milk-cows forms part of the establishment; and cheeses, on the Cheshire plan, are made of good quality, all of which find a ready market at $6 \mathrm{~d}$. per lb. at the dairy.

Within a few miles of Newport, Lord Lucan has an extensive tract of country, which he is enclosing: I had here the good fortune to meet with his lordship, when he kindly entered into many details as to the management he proposed to adopt. In this place he has 6000 acres, which he is dividing into four farms of 1500 
acres each. The land here is hilly; the hollows of each farm will, when drained, be the arable part-the rising ground is intended for grazing. Lord Lucan will build suitable farm-steadings and substantial enclosures; he will drain it where necessary, remove all obstructions to tillage, and give a 19 or 21 years' lease. Rent of each farm about $£ 600$, and poor-rate guaranteed not to exceed 1s. per acre.

Lord Lucan has been much blamed for dispossessing the people who formerly held the land. It is not for me to discuss that question, nor have I all the information which would be necessary for any one to form a satisfactory judgment upon it; but when the amount of employment he is now giving, and the superior style of husbandry practised on his farms, are taken into account, it may be doubted whether the former possessors could earn as much by the miserable cultivation of their own lands as they now do in the capacity of hired labourers. There can be no doubt of the vast increase of the total annual produce under the present system, and the gain to the entire community must be the greater by the amount of that increase.

Lord Lucan is probably the most extensive tillagefarmer in Great Britain. He has at present upwards of 10,000 acres under his personal superintendence, having farm-stewards on the different farms, who all take their instructions from himself. He had this year upwards of 1000 acres of white crop, and between 400 and 500 acres of green crop. He has a stock of 800 cattle, 60 of which are working bullocks, and 600 sheep. He has 40 work- 
horses, and gives daily employment on his farms to 600 men, including those who are making drains, \&c. The whole of this extensive establishment is managed in the most orderly and systematic way-each department has its separate head, who is answerable for it alone-and the quiet and regular progress with which everything is going on at once convinces the spectator that the ruling mind here is defective neither in energy nor skill. It is a great and most important experiment, and assuredly deserves to be successful.

Landlords generally, even those of the highest class in the empire, might do well to take a lesson from the example of Lord Lucan. He has not thought it beneath his station to acquire an intimate practical knowledge of his OWN BUSINESS - the management of his estate. The want of this essential requisite to the profitable ownership of land, has done more to retard the agricultural advancement of the country than can well be calculated. It has led to the very general appointment of a class of agents unqualified by previous education for the important duties they ought to perform. It has exhibited an unreasoning jealousy towards prosperous farmers, whose exertions, instead of being encouraged, are only regarded as a source of increased rent. It has crushed, by culpable negligence, the efforts of the industrious tenant, willing to struggle against adverse times, if only fairly met by a considerate landlord. It forms the true solution of the different success which distinguishes the commercial and manufacturing capitalist from the great landlord. The first makes his business 
a study, and develops it to the utmost; the last too often thinks it beneath his notice, and trusts it to persons who are frequently as ill qualified for its duties as himself.

It may not be possible, and probably would not be desirable, that many should imitate Lord Lucan in the extensive occupation and cultivation of their own lands. But it would be of vast importance to themselves, their tenantry, and their successors, if our great landlords on both sides of the Channel were in some degree to emulate him in the personal study and attention which he devotes to the practical business of his estates. 


\section{CHAPTER III.}

CASTLEBAR-UNION WORKHOUSE-GAOL-CHARITABLE RELIEF WORKSNEWPORT-SIR RICHARD O'DONNELL'S ESTATE-FLAX CULTIVATIONCOURTRAIS METHOD OF STEEPING-CLEW BAY-WEST PORT-MARQUIS OF SLIGO'S ESTATE-STOCK FARMS - KILLERY HARBOUR - KYLEMORE - MAUME-DOORUS-CLONBRUCI-ROSS-LORD LEITRIM'S DEMESNEASHFORD-SUBTERRANEAN RIVER-CANAL.

ON the 11th October I visited the union work-house at Castlebar, and was conducted over the whole establishment by the chairman of the paid guardians. The house is very extensive, every part of it seemed clean and well ventilated, and it appeared in all departments to be conducted in the most orderly manner. The gate was surrounded by a crowd of applicants for admission, in which misery of every kind was represented. The financial position of this union (population 61,063) is deplorable. The annual rental of the land which it embraces is $\mathfrak{L} 49,988$. The estimated expenditure for the poor to 29th September last, for twelve months, $£ 31,068$. The rate per $£ 1$ on net value ranges from 9s. $7 \frac{1}{4} \mathrm{~d}$. to $26 \mathrm{~s}$. $7 \mathrm{~d}$. The gross debt amounted, on 25 th

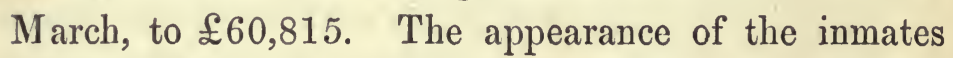
in the day rooms was listless and indifferent, and troops of children were being marched about the grounds for exercise.

The county gaol is a large and well-constructed build- 
ing. I was shown over it by the governor, and found everything very clean, and apparently well conducted. The prisoners in their different yards were marshalled in single file along the walls for our inspection. The first impression one received by looking at them was that of a cold shiver; for the weather was frosty, and the teeth of many of the poor creatures were chattering with cold. Hopeless wretchedness was the prevailing expression in their countenances; many bore the marks of pinching want-their contracted features, and keen eye, and ape-like faces betokening the lowest grade of humanity. Some well-fed scoundrels there were, but not many ; and one could not look round these rows of miserable beings without shuddering at the idea of an innocent person, on suspicion or wrongly convicted, being forced to herd with such companions. The average number of prisoners confined in this gaol is about 400 . The offences, as recorded in the prison-book, seemed chiefly petty thefts ; for instance, "stealing a hen, value sixpence," "stealing turnips," "rooting potatoes," and so on ; "taking relief meal from Bridget Mooney." Many were of a deeper dye-viz., for stealing sheep, cattle, or horses ; some for assaults ; some for running out of the poor-house, and some for making forcible way into it.* There were no crimes of the most serious nature, such as murder, or premeditated attempt at it.

* This reminds one of the story told of one of our northern judges. Hearing an altercation at the entrance-door of his court-room-" What's that noise?" he demanded of the door-keeper. "It's a man wanting in, my lord."-" Keep him out," was the peppery rejoinder. By-and-by there was a noise again. "What's that now ?" demanded the judge. "It's the man wanting out, my lord." - "Keep him in, then," was the judicial award. 
Indeed, the great proportion of the cases seem naturally to arise out of the entirely deranged state of society which exists in this part of the country.

The town of Castlebar has suffered much from the effects of the late famine, the industry of its inhabitants having been paralysed by the cessation of all demand from the surrounding country. To obviate as much as possible the misery resulting from this, a society was organised by a number of benevolent individuals in the town, of whom Messrs Curley and Gerraghty, the Roman Catholic curates, took the lead. They purchased a quantity of wool, and then employed the different artisans of the town in spinning, weaving, dyeing, shaping, and sewing it into suits of clothing. Upwards of one hundred individuals, representing several hundreds of the population of the place, have thus received constant employment at their several occupations during a time when the natural sources of employment have been in abeyance. Excellent suits of frieze clothing (five hundred of which have been purchased by Count Strelitzki for distribution in some other distressed part of the country) can be supplied for 10 s. the suit. When these are sold, the original subscribed fund will be repaid, and the society enabled to continue their benerolent scheme, should the necessity of the time still require it. The efforts of these gentlemen were not confined to the town of Castlebar. They foresaw the misery that must fall upon the small holders of land in the surrounding country, if no effort was made by them to cultivate their holdings, and so provide a store for the coming winter. The potato having failed, these poor people had nothing 
to fall back upon, neither money to buy seed, nor skill to use it properly when they got it. A relief committee was organised by the same benevolent individuals, assisted by Mr Murphy as their treasurer. They collected subscriptions to a considerable amount, principally from England, which they expended first in purchasing turnip seed, a portion of which was given to each individual, with directions how to manage it. Inspectors were appointed, who went to each holder, and then paid him in advance for a fortnight's work as laid out to him on his own land, the rate being $1 \mathrm{~d}$. a-day for each individual in a family. At the end of the fortnight each person was again visited; and, if the allotted task had been completed, he was again paid in advance, being at the same time instructed as to the next fortnight's duty. If any one neglected to do his task, he received nothing till it was completed; and if the same indolence was continued, he was struck out of the list altogether ; but it was scarcely in any instance necessary to resort to this extremity. Nearly four hundred families were thus maintained on their own lands in industry, during all the summer, at a cost of little more than $£ 400$; and now that the summer is ended, the land which would otherwise have been waste, is carrying crops of turnips, cabbages, \&c., which will be a great help to the poor people during the winter. Being anxious to see whether much real benefit had resulted from this benevolent plan, I visited several of the small holders, occupying an acre or so of land, who had received this assistance, and found them most thankful for the arrangement by which they had so greatly benefited. They had fair crops of 
turnips, which they were mixing with their potatoes to make the latter go farther as food. When the potatoes are done, they will mix the turnips with a little Indian meal, with which food they hope to manage to "make out life" during the winter. This is an instance of relief laid out in a reproductive manner, and the cost of management did not exceed 2 per cent on the expenditure; but this of course arose from the gratuitous services of the gentlemen forming the committee. Surely such deeds of benevolence are worthy of record, and none may grudge the honour that is due to the truly Christian philanthropy of the good Fathers Curley and Gerraghty. If more of our Christian ministers were actuated by the same spirit, we should have fewer scoffers at religion.

From Castlebar to Newport the road is not very interesting. The latter is a clean little town, situated on the side of a wooded river, which here falls into the sea at the head of Clew Bay. The principal proprietor of this place and the adjoining country is Sir Richard O'Donnell, Bart., whose hospitable mansion, immediately adjoining the town, I reached on 11 th October. Next morning I accompanied him on a walk over part of his estate. He offers 5000 acres, lying together, the nearest point within a mile of Newport, part of it on a lease for 200 years, the rest three lives, or thirty-one years, at an annual rent of $2 \mathrm{~s}$. $2 \mathrm{~d}$. per acre, besides the rates. The land is all situated at a low elevation, ranging from 30 to 60 or 80 feet above sea-level. Half of it is said to be capable of regular cultivation; the rest is fair pasture for Highland cattle, 
and very improvable. Sea-weed and coral-sand can be got at the sea-beach, which is within about half a mile of the lands, for 1s. a boat-load, containing about four cart-loads. Upwards of 100 acres of this tract have been drained, and enclosed with substantial stone fences; and a commodious barn and other houses have been erected. I walked over part of the improved land, and found it deep, strong soil, with a good many large stones in it, and susceptible of much improvement by draining. Flax is cultivated on it with success ; and I was assured, to my surprise, by a farmer of Sir Richard O'Donnell's, that the oats here produced sometimes weighed as much as $46 \mathrm{lb}$. a bushel.

The same proprietor has plenty of other land, which he is anxious to let. That which lies along the seacoast appeared to be of good quality, and, from the peculiar conformation of the coast, it did not seem to suffer from exposure to the Atlantic. Clew Bay is very peculiar. Its spacious basin is sheltered by the lofty Clare Island, which shuts it in from the ocean; and along its coast there are hundreds of little islands, affording shelter to the jutting points of the mainland; while numberless indentations of the sea, running a mile or two up into the land, give safe and convenient watercarriage to every part of the coast. On many parts of the sheltered sides of these bays and islands, wood grows to the water-edge; and, under careful management, they are capable of being made most picturesque. The climate is mild, and the soil very suitable for green-crop husbandry.

Sir Richard O'Donnell has exerted himself greatly 
to introduce, with an improved husbandry, the growth and manufacture of flax. He has erected flax-mills at Newport, which are now let to Mr Bernard, a Swiss gentleman, who kindly explained to me every part of the improved process he adopts in steeping and scutching. He manages the flax on the Courtrais or Belgian system, steeping it in warm water, heated to 90 degrees by steam-pipes passing through the steeping vats. In this way the process occupies only sixty hours, which, by the old method, took two or three weeks. After being steeped, the flax is dried in the open air if the weather suits, or in drying sheds, which are cheaply constructed. It is then sorted and taken to the scutching-mill. The whole of the finer portion of the flax is sent to Belfast, where it is sold to the spinners; the refuse, or tow, is woren into sacking, and made into bags, as, from its low value, it would not pay carriage to send it far in the bulky unmanufactured state. This factory gives employment to about three hundred people in Newport throughout the year, and works up the produce of several hundred acres, yielding to the farmer, under the present imperfect cultivation, from $£ 6$ to $£ 9$ an acre. The seed, which is separated from the flax before it is steeped, is reckoned to be about onefourth the value of the crop. The steeping process adopted here greatly simplifies the management to the farmer, as in this way he grows and pulls the flax, and then stooks and stacks it like a corn crop, selling it to the manufacturer when it best suits either party, and without having any intricate process to attend to. The machinery seemed simple, and requires neither large 
capital nor great skill to conduct it; so that, where desirable, this manufacture might be very easily extended.

In driving along the road, we occasionally disturbed the labours of the husbandmen threshing out their crops. They choose a dry smooth part of the public road for a threshing-floor, and winnow the corn by riddling it slowly in a breeze of wind. We drove over the top of several heaps of half-threshed corn in the middle of the road, the threshers suspending their labours till we passed.

From Newport to Westport the country is of an undulating character, the road skirting the heads of the numerous inlets of the sea, though, from the peculiar character of the coast already mentioned, a glimpse of the sea is scarcely to be got the whole way. The distance by road is six miles; following the coast-line, along every bay, it is not less than sixty. The land generally is under wretched management, though the farm of Mr Bridges, a tenant of Sir Richard O'Donnell, is a striking exception. The neat fences, good roads, and comfortable residence, with the trimly thatched stacks, here led me to make some inquiry about the tenant; and I learned that his father had been an English settler, and that he himself had been educated in England.

Westport is a very prettily situated seaport town, also on Clew Bay : the houses are handsome and well built; and nestled as it is in a hollow, with a row of trees overhanging the stream which intersects it, and in the immediate neighbourhood of the fine demesne of West- 
port House, the residence of the Marquis of Sligo, it is quite a place in which the traveller will feel desirous to spend a leisurely afternoon. The trees around Westport House are of great size and raried beauty, and, with the verdure of the park at this season, indicate a mild soft climate.

Lord Sligo kindly accompanied Mr Elwood and myself through part of his estate. The country soon becomes hilly after leaving Westport on the way to Connemara. The lofty Reek, or Croagh Patrick, forms a grand object, running up from the edge of the sea to a conical peak 2500 feet high, perfectly shapely and smooth. The greater part of this hill-country, till you reach the Killeries, belongs to Lord Sligo, who is anxious to let his lands to tenants of capital and enterprise. He would sell a portion in any part of his estate, if he could thereby induce the purchaser to reside in the country and assist in its improvement. In the valley of the Errive, about five miles from the head of Killery Bay, he would let a hill-farm of 5000 acres, on a lease of three lives or thirty-one years, and give a lease in perpetuity of the land on which the tenant built his house. This farm is bounded by the river Errive, along the bank of which there is a considerable tract of alluvial land, and gradually rising from it an extensive natural wood of great beauty, in which a residence, commanding a magnificent mountain landscape, might be most picturesquely placed: behind this, the land quickly runs up to a high mountain. The whole forms a good sheep-walk, with feeding for cattle, and some 40 or 50 acres of low ground of good quality for 
cultivation. An excellent public road runs along its whole extent. This farm would at present be let for $£ 120$.

From this point to the Killeries the valley widens and improves, the natural produce of the soil being sweet short grass in the low grounds, with strips of verdure running up the hollows of the mountains. Several good stock-farms might be got in this quarter ; but for many miles in this direction not a sheep or head of cattle is at present to be met with. The sheep were said to have been stolen during the famine, and the holders of the lands had not the means of putting a new stock on them.

At the foot of the valley we came upon the harbour of the Killeries, which is an arm of the sea running up between high mountains for some eight miles, till it receives the waters of the river Errive. There are here some cottages for sea-bathing; and certainly few spots in the British islands could be selected, which unite more beauty and grandeur of scenery with such perfect retirement.

Passing down the south side, a view of the Atlantic is got in the distance; while on the opposite side of the narrow bay towers Muilrea, the highest mountain in Connaught, rising directly from the sea to a height of 2700 feet. The road then leares the sea and crosses the moors to the south-west, affording a fine view of the Connemara mountains. We are now in an unpromising tract of country; the moors are very barren, and not a sheep or a house to be seen on them for miles. 
At Kylemore there is an inland lake of considerable beauty, shut in on all sides by conical mountains. At the western extremity of this lake lies the farm of a young Englishman, from Lancashire, who, with several brothers, has settled in this country. Their choice of a location has not been fortunate ; and it may be doubted, whether the capital expended in erecting expensive farm-buildings, in a tract where the soil and climate forbid cultivation, will be reproductive. If the same energy and capital had been employed on some of the fine arable lands of Mayo or Galway, how different would the result have been! Strangers should not too rashly expend their capital, in the vain hope that they can at once import the agricultural management of an English county, into a region where the soil and climate are totally unsuited for such a change. But neither must any general conclusion be drawn from the result of such an experiment, adverse to investments judiciously made in more favoured districts of the West of Ireland.

Remaining all night at Kylemore with two parsons who keep a hotel here, and help to entertain the traveller, (thus adding to their cure of souls a personal attention to the wants of the body, ) we returned next morning to Leenane, thence up a valley through Joyce's country to Maume, at the western extremity of Lough Corrib. Great part of this valley is very suitable for sheep-farming, the mountains affording much sweet pasture, as also the slopes and banks of the river. From Maume to Cong the road sweeps along the north-west side of Lough Corrib, the country being very 
stony and in miserable condition, though capable of much improvement. As the car slowly toils up some of the steep ascents on this road, the traveller may turn aside for a moment to enjoy the beauty of the scene. Beneath him lies an arm of Lough Corrib, which, with its many islands, stretches away to the east; before him is one little isle with its old ruined castle, the fastness of some ancient Irish chieftain, while in the distance are seen the desolate moors and fine mountains of Connemara.

At Doorus, a promontory of 500 acres running out into the Lough, the land improves ; and this, with about 1600 acres more adjoining it, and stretching up into the hills, is for sale. It is occupied by a great number of small farmers, but is very capable of improvement, and, if judiciously laid out into small farms, might become a profitable investment. It would require a considerable outlay of capital to provide suitable houses for such tenants, and give them every encouragement, which they would need; and a resident landlord, devoting himself to the task, could alone make the experiment with success.

Some way further on, the road branches off to Clonbruck, in the neighbourhood of which, on the margin of Lough Mask, is the house and demesne of Lord Leitrim. The wooded islands in front of the house, with the lake and the distant mountains, form a very pleasing scene. Within the demesne is situated the parish church of Ross, built chiefly at the expense of Lady Elizabeth Clements. It is a small chapel, capable of containing about sixty persons, but it is all of exquisite workman- 
ship, both within and without. The windows, of stained glass, are in the highest style of the art ; and the woodwork and roof, which is open to the ridge, are of carved oak. This little church is quite a gem, and will well repay the time occupied in deriating from the main road to obtain a view of it.

We next proceeded to the estate of Ashford on Lough Corrib. It comprises 1100 acres, very stony, but deep dry land, suitable for grazing or crops. The situation of the old mansion-house, at the entrance of the river into Lough Corrib, is very beautiful. The grounds are undulating, and, in the demesne, plentifully interspersed with wood, much of which is old, and highly ornamental. This estate is for sale, and would make a most desirable investment for a man of moderate capital. Bounded, as it is on two sides, by the river and lake, it is very conveniently situated for water carriage; and in clearing the ground of stones, (which would be the heaviest outlay in improving the property,) thousands of loads could be tumbled into the lake, where they would be entirely got rid of. The best of it, comprising the demesne and deer park, between 200 and 300 acres, could be kept in hand by a resident proprietor; and the rest, which is all arable, could be either subdivided into well-arranged small farms - for its very stony character forbids extensive tillage-farming-or laid down to grass, and let for grazing. It is immediately opposite to the old abbey and town of Cong, where the last O'Connor, king of Connaught, was buried. There are sereral singular caverns in the limestone rock on this estate; and one in particular, where, after descending 
serenty or eighty steps, you come to the bed of the subterranean river which flows from Lough Mask to Lough Corrib ; and when it is lighted up by the blazing torch of the guide, who, as he jumps from rock to rock, drops burning sparks, which are instantly extinguished in the black silent stream, the effect is striking and not unmingled with awe.

In the afternoon, I walked up the new canal, at present being formed to open a navigable passage from Lough Corrib to Lough Mask. Upwards of 300 men are employed on it. Besides opening up this communication, it is expected to reduce the waters of Lough Mask permanently to their summer level, and thereby drain an immense tract of low country on the river Robe and its tributaries in Mayo. I was informed by Mr Collins, the resident engineer, that the men employed were all natives of the province; and he found their workmanship, now that they were taught, as good in building dry masonry as that of experienced English workmen. The men, all along the line, were working with as much diligence and assiduity as I have ever seen in England. They are employed in gangs by task-work, and their diligence affords a remarkable contrast to the indolent style of work which I observed wherever the labourers were paid by daily wages, unless they were, at the same time, under the most vigilant superintendence. This great operation is expected to be completed in two years. The whole cutting is through solid limestone rock : horizontal, lying on vertical beds. It is ererywhere split into great crevices or "swallow-holes," and these require all to be puddled; but nature, everywhere 
bountiful in this country, has placed the very material required for this purpose in the hands of the workmen - a bed of the finest plastic clay (called by the men "California,") having been cut into in the course of the operations.

As illustrative of the effect of task-work, and the physical ability of the labourers of this district, I quote from the Annual Report for 1848 of Mr S. N. Roberts, C.E.- "The works throughout the entire district have been executed by task, strictly in accordance with the commissioner's instructions; and I cannot advert too strongly to the necessity there was for the strictest attention to this, for I never witnessed more want of power of exertion than among the labouring classes in this part of the country, when first the works were commenced. With the exception of a few quarrymen, found in the town of Galway, they were unskilled in every class of public work; there were many instances where gangs of men did not earn more than threepence per day, although allowed full prices for their work. Generally speaking, however, the men are greatly improved in habits of industry, and, of course, in the amounts of their earnings. But the greater portion of them are so perfectly destitute, and so wretchedly fed, that it would be impossible to enable them to realise a rate of wages calculated to support them in a proper manner, without paying prices which the economical execution of the work would not permit."

Here ended my tour of Mayo, a county containing agricultural resources which may be shortly recapitulated. It is nearly all, except the northern mountainous parts, 
situated at a very moderate elevation above sea-level. It consists generally of a deep dry soil, very suitable for green crops and grass. Along Lough Mask and Lough Corrib, the land is very stony, and can be profitably cultivated only in small farms, or laid out to pasture. The middle and eastern portions of the county present fine open plains for extensive farms, in every way suited to a high system of cultivation. All this part of the country contains within itself abundance of limestone, and "turf" with which to burn it; and almost every large farm might have a portion of bog attached to it, to be annually reclaimed, and which would add much to the resources of the dry land. The bogs generally contain, either beneath their surface or on their margin, abundance of limestone gravel, and sometimes shell-marl, with which they may be mixed and enriched. The lands, when laid to grass, are soon covered with white clover, and throughout the district there is plenty of fine old feeding land. In the northwestern division, returning from Castlebar to Newport and Westport, the country is hilly, and not so well adapted to tillage. Limestone cannot be got so cheaply, but, near the sea, coral-sand and sea-weed may be readily obtained. The western and northern mountainous districts afford pasture for hill flocks, which might be profitably managed in union with the turnip farms of the south and middle divisions. One advantage of these high districts, as compared to hill-farms in the north of Scotland, is, that their winters are never severe, and, consequently, the expense of smearing the sheep with butter and tar, as required in Scotland, is saved. 
Excellent stones for building and fencing can be had everywhere ; and, generally, there is not a great outlay needed in thorough draining, on account of the natural dryness of the soil. The farms recommended are chiefly held by the landlords themselves, or by non-resident graziers. The roads everywhere are good, and a happy exemption is enjoyed from that most costly, wasteful, and rexatious system of collecting a revenuetolls. The people are peaceable and intelligent, and willing to work if properly looked after; and wages being low, all kinds of manual labour can be executed at a very moderate cost. When the railway from Dublin is opened to Galway, the nearest station from the better parts of Mayo will not be more than from thirty to forty miles distant from a point whence Dublin may be reached in five hours. There is room in this county for hundreds of farmers of skill and capital, to whom nature affords a fair prospect of success. But they must select their location with care and skill, having regard to both soil and climate; and let them not rashly expend the capital, which they will require for cultivation, in erecting farm buildings, which are solely the landlord's business ; and let them come to a precise and definite understanding with their landlords, as to a limitation of rates and taxes, until some provision shall be made by law for protecting those who expend their skill and capital in improving and cultivating the soil, from excessive rates, and above all, from an increase of rates through the higher valuation consequent on their improvements. 


\section{CHAPTER I V.}

OUGHTERARD TO GALWAY - ANNAGH - MR BODKIN'S FARMS - TURLOUGHS

- CARRYING OFF CROPS - BALLINAHINCH - "THE MARTIN ESTATE" CLIFDEN-CLEGGAN-INLETS OF THE SEA-DERRYGIMLACH-ROUNDSTONE - PEASANTRY OF CONNEMARA - TASK-WORK - DESCRIPTION OF MARTIN ESTATE ON LOUGH CORRIB-FARMER'S HOUSE-BREAK DOWN -HEAD OF THE BAY OF GALWAY-ARDFRY-MR SKILLING'S FARMNORTH SHORE OF GALWAY BAY-TOWN OF GALWAY.

Leaving Cong on the morning of the 14th October, I sailed for nine miles down Lough Corrib to Oughterard, where I met the Clifden mail, and reached Galway in the afternoon. While I remained at Oughterard, a strange contrast attracted my attention. Crowds of clean, well-dressed country-people, with scarce a ragged coat or an old hat among them, were hastening towards the Roman Catholic chapel, round the eastern door of which, sub Jove frigido, were rows of kneeling worshippers; and at about a hundred yards farther on, stood the church of the Establishment, with armed sentries pacing before the door keeping watch on the piled arms of their comrades who were within the building. May the time soon come when it will be unnecessary to continue an exhibition so incongruous with the character of Him who came to preach peace and goodwill among the children of men !

Leaving Galway on the morning of 15 th October, I 
proceeded to Annagh, eleven miles to the north-east, and about five from Tuam, passing through a bare stony country, uninteresting to the general traveller, though far from valueless in an agricultural point of view. At Annagh I met Mr Hunter, drainage inspector for Galway, who kindly accompanied me during the rest of my tour in that county.

Mr Bodkin, of Annagh, drove us to Cloonmore, a farm of his within two miles of Tuam, which we examined. It comprises 380 Irish acres, (615 English,) all in grass. About the half of these are alluvial land, which has never been ploughed, having been hitherto a "Turlough" always covered with water in winter, but now, by means of the arterial drainage, laid completely dry. The rest of the farm is about one-half old grazing land, of prime quality, and the other half, dry land of fair quality. The stock kept on the farm last season, according to the statement of the shepherd, was 200 cattle, 2 and 3 year-olds, and 600 sheep, 2 and 3 year-olds, during the summer; 300 to 400 sheep, but no cattle, during the winter. The proprietor will give a thirty-one years' lease, but the tenant must build such houses as he requires. At present there is a herd's-house and the shell of a cottage, which, with a moderate outlay, might be made into a good cottage residence. This is an excellent farm, almost all in good condition, and more than half of it as fresh and unexhausted as an American prairie. A good tenant will not be hampered with troublesome conditions in his lease. It is within about fourteen miles of the railway to Dublin. The present rent paid is $£ 315$, the 
half of a 5s. poor-rate, and the county cess, which here does not exceed 1s. in the pound. The land is not at present under tillage, being occupied merely for grazing.

Next day I examined several of Mr Bodkin's farms in the neighbourhood of Annagh. He could let five or six farms here, ranging in extent from 400 to 700 English acres each, and within seven to ten miles of a railway station, when the line is opened to Galway. They are on limestone, dry turnip-land, and under good management would prove sound and not ungrateful, though not possessing the naturally rich qualities of many of the farms already described. One of them will have attached to it a Turlough of nearly 150 English acres, now laid dry by arterial drainage, and capable of feeding a very heavy stock of sheep, cattle, or milk-cows. Lord Oranmore's estate here contains large breadths of these drained "Turloughs," many hundred acres of which, in this quarter, are expected to be laid permanently dry by the arterial operations at Turloughmore. They generally consist of alluvial soil of the finest quality, the silt and debris for ages of a limestone country, and covered with a thick sward of grass, which, by the closeness with which it has been eaten, indicates the rich feeding qualities it possesses.

Though I give the particulars of Mr Bodkin's farms only, it is right to say, that almost every landlord in this county is equally anxious to get good tenants.

The arterial drainage of Turloughmore has changed the ancient "course of the water, and thereby for the present laid dry the bridge over the old water-course. 
The numerous arches of this bridge are now occupied by " ejected" families, and the traveller, as he crosses, is surprised to find himself half stifled with the smoke of their fires. One cannot help a feeling of dread that, in some winter flood, the new course may be found an insufficient outlet for the water, which would then overflow into its ancient channel, and sweep every one of these poor creatures away.

In walking through the fields, an incident occurred which may be worth mentioning. A man came breathlessly up to the gentleman with whom I was, and begged his interposition as a magistrate to prevent bloodshed. We immediately repaired to the scene of action, and found about sixty people assembled to resist the armed police and a bailiff, in an attempt they were about to make to seize a rick of corn, which was alleged to have been carried off from the land of a neighbouring proprietor, where it had been under seizure for rent. The people were in a state of great excitement, the police had their guns cocked, and things looked very serious. On inquiry, it appeared that the bailiff had no better proof than a suspicion raised in his own mind, from the fact that the party in whose yard the disputed grain was stacked was the son-in-law of the party whose crop had been made away with. As there were other ricks in the yard of the same description, and several persons were willing to swear that all these ricks had been in that yard before the day on which the stolen crop was carried off, it became a very difficult matter to say who was right. It was clearly not to be wondered at that the whole village should turn out to protect the crop of a friend, if they believed 
that crop to be his; and it was equally clear that the man himself who owned the crop, if he really knew it to be his, was obeying a very natural impulse in defending it. But the orders of the police were peremptory, and, but for the interference of a gentleman present, who gave his guarantee that the rick would be forthcoming on sufficient proof being exhibited that it really was the one which had been carried off, we should very probably have had a scene of bloodshed arising out of this very simple matter. The whole rick in dispute was not worth more than 30 s., and here were sixty men idle, and ten police, with four carts and horses, wasting their time fruitlessly. What a system it is, when tenant and landlord are on such a footing!

Returning by Galway, we proceeded to Ballinahinch by the Clifden mail, on 17th October. The day was wet, and unfarourable for seeing the country. Ballinahinch is the mansion-house of the Martin estate in Connemara, now for sale, about which so much has been said. It is some thirty miles west of the town of Galway. After leaving Oughterard, the road passes through this estate for about seventeen miles, keeping along the valleys among the hills, the soil of which is mostly mountain-bog of the poorest quality. There are many lakes by the road, and one or two with pretty wooded islands and banks, which would make excellent sites for shooting or fishing lodges. There seemed to be no stock whatever on the moors, and most of the small patches of land which had been cultivated were deserted and waste. Near the Lough, above "Flinns," the half-way house between Ballinahinch and Oughter- 
ard, the land appeared somewhat superior, and suitable for a better class of sheep stock. A good hill-farm might be made here, and the banks of the Lough present many eligible sites for a residence. The fishing in these lakes, and in the rivers which flow from one to the other, is said to be excellent; and the shooting no doubt might, with care, be much improved.

The mansion-house is a good comfortable house, well situated on the bank of the river which flows from the lakes to the sea. The western slopes of the river and lake, adjoining the house, are wooded, and the grounds laid out with walks leading to the boats and stables, which are nearly a mile distant. An old castle, on a small island in the lake, with a fine conical mountain behind it, adds greatly to the picturesque effect of the scene. The quality of the land for miles around is heathy mountain, fit to carry small blackfaced sheep and West Highland cattle. After a walk over the neighbouring hills of five miles, I cannot say that I saw anything of a quality much superior to this. Improvements certainly are going on, on a neighbouring property, but in my opinion they will never pay as a remunerative money inrestment.

Next day we visited Clifden, rather a good town, prettily situated at the head of one of the numerous inlets of the sea, which are everywhere met with on this coast, as the translation of the word Connemara, "Bays of the sea," sufficiently indicates. This town has suffered much from the effects of the late famine.

Proceeding northwards five miles, we reached Cleggan, another division of the Martin estate, and walked 
carefully over it. It occupies the peninsula between Cleggan and Ballynakill Bays, and forms, with the ancient tower on its summit, rather a prominent feature on the coast. The bay affords sea-weed and coral-sand, and abounds with fish and salmon in their season. An inland lake, separated by a narrow strip of land from the sea, communicates with it by a stream, and in this and the lake great quantities of salmon are occasionally got. As many as one hundred and forty fish have been taken at two draughts of the net. At the sea-mark, and also at the upper part of this lake, the limestone makes its appearance, and is very valuable in this district of clay and mica slate. This property has a good sunny exposure, slopes gently up from the sea, and contains several hundred acres of good arable land, light, but deep and easy of cultivation, and might, without very heavy outlay, be made a profitable tillage farm. An excellent road runs nearly entirely through it, and several small lakes afford good falls for threshing-mills and other agricultural machinery. The higher part of the land is suitable for sheep and cattle, and is capable of much improvement as pasture. The opposite side of the bay, and the land towards Clifden for some distance from the bay, form part of the same estate. These lots comprise altogether nearly 3500 English acres, and would make a good estate, if bought at a moderate price. The latter portion, containing upwards of 1800 acres, are much inferior to Cleggan; but the estate would be more complete by getting the whole together. Lots 83 , 84,85 , and 86 , on the plan of the estate, are the Cleggan division ; 80 and 81 , the south side of the bay. 
Returning towards Clifden, the land along the inlets of the sea seems generally of an improvable character. Southwards from Clifden, towards Roundstone, the road crosses by bridges over the neck of several of the sea inlets already mentioned; and to a stranger these present a very singular appearance. The tide was rushing in through the bridges, with great velocity, at the time we passed. The coast for several miles is very low, being only a few feet above sea-level. It is rocky; and in some of the few patches among the rocks, which had been left untilled, the pasture was sweet and green.

Derrygimlagh, lot 65 of the Martin estate, extends for about two miles along the shore, comprising 2700 acres, 350 of which are lakes. Sea-weed and coral-sand may be got in any quantity; and as the land is quite level, and an excellent public road runs along the coast, the labour of drawing it from the beach would be very light. The land, however, from its extremely rugged character, is not much suited to tillage; but there can be no doubt that, if it were enclosed, and main drains constructed to draw off stagnant water, it might then, by the application of seaweed and coral-sand, be brought into good grazing ground. Salmon and white fish are got in the bay. There seemed to be a considerable population still on this property, although the mortality during the famine was dreadful, not fewer than eight hundred persons, young and old, as I was informed, having died on this lot alone.

From this point to Roundstone, except the first mile, which is much the same as Derrygimlagh, the country is very stony and barren. From Roundstone to Ballynahinch, on account of night beginning to set in, we 
could get only a glimpse of the country ; but in general it seemed, like most in these parts, a succession of wet heathy moors. The road winds picturesquely up the river, which here and there expands into lakes; and after being drenched with rain, we again reached the mansion of Ballynahinch.

The peasantry of Connemara are very intelligent, and make good workmen, when fairly treated and well managed. I was assured by a Kildare man, who manages a small property in this district, that he could get more work done in Connemara for 8d. a-day, than in his own county for $1 \mathrm{~s} .2 \mathrm{~d}$. He pays wages every night; and the people, getting their money regularly, and knowing what they are to get, work well for it. The employers of labour generally, in the west of Ireland, are not overburdened with ready money. They do not pay their labourers with regularity, and accordingly the people become disheartened, and their labour is then indolently and very grudgingly given. I am assured by a gentleman who occasionally had under his direction the employment of several hundred men, that he at first found great unwillingness on their part to taskwork ; but after some trial with them, they became very fond of it. And what was the reason? Their former employers had given them task-work; but at the end of the week, finding that the people were earning more than the usual rate of wages, they lowered the contracts, and thus discouraged the system altogether. As soon as the men found that the rate for their work was lowered in proportion as they the more exerted themselves, they naturally became disgusted with task-work. 
But this gentleman continued the same rate throughout; and the men, finding that they were not taken advantage of, worked willingly, and made good wages.

Returning from Ballynahinch on 19th October, we examined several of the lots of the Martin estate, lying along Lough Corrib,* to the north of Oughterard. That part lying between the public road and the lake is highly improvable, consisting generally of dry, light land, very suitable for green-crop husbandry, and not difficult to bring into good grass, if well manured. Lots $35,36,38$, and 39 , comprising 4350 acres, have each a frontage to the lake. There are numerous beautiful situations on which to build. The succession of bays and rounded promontories, with islands, scattered about the lake, some of them beautifully wooded, afford spots suited to various tastes. The beach is a clean white gravel, and boats can touch at almost any part of it. Sea-weed is brought from Galway in boats, and limestone from any part of the opposite shore. When steamers ply on Lough Corrib, as is contemplated on the opening of the canal at Galway, to which I will have occasion afterwards to refer, the scene will be much enlivened, while the convenience of communication will of course be greatly increased. A new road along the side of the lake from Oughterard is formed, and might at very little cost be completed. This property is at present badly cultivated. There is some extent of bog on it, which might be easily reclaimed, especially if the

* This fine lake, which is from twenty to thirty miles long, washes a great tract of country, part of which, on a different side, I had previously visited. 
drainage of Lough Corrib lowers the permanent level of that lake, as is expected. Altogether, these are very eligible and improvable lots, and, if purchased on moderate terms, might be made a fine property. Care must be taken to ascertain exactly how the existing leases stand, for on the length of these will greatly depend the value of the purchase. But, in my opinion, the Martin estate, as a whole, is not adapted for the nucleus of any comprehensive scheme of settlement, notwithstanding the advantages which some of its lots present for the separate investments of private individuals.

We were shown over this property by a farmer who holds a considerable part of it, and who kindly asked us into his house during a heary fall of rain. The house outside looked rather neat, and is very prettily situated close to the Lough. Inside, it is impossible to describe the dirt and confusion. We entered by the back, as the front door did not appear to have done duty for a long time. Around the kitchen fire were seated and squatted a number of men and women, very dirty and ragged. In the inner room, to which we were shown, were all sorts of things-fishing-nets, saddles, chairs, spades, sideboard, \&c. A mutilated ale-glass was produced, which one hulking fellow was ordered to wash, while another was despatched for water. The owner made up for all by a very hospitable welcome; but the fact that he appeared quite unconscious of any defects in his household appointments, showed how very low the standard of comfort must be among this class. A ploughman in Scotland would be ashamed to have his 
house so scantily provided, and this man had several servants, and occupied a considerable farm.

The rain came down in pitiless torrents, as we walked back two dreary Irish miles to Oughterard. Wet into the skin, we started by car for Moycullen, where a car from Galway had been ordered to meet us. After driving a few miles, smash went one of the wheels, and we were spilt on the wet road. "What will I do now?" cries the despairing driver. "Ride your horse this instant to Moycullen, and send the other fellow forward with his car for us." After a short delay the horse is mounted, and Jehu disappears through the driving rain. By this time it is quite dark, and we proceed on foot:

" Tramp, tramp across the land we went, Splash, splash across the sea ;"

for in many places the roads are ankle-deep with rain. No car appears, and, after walking nearly an hour, Moycullen is reached at last. There, warm and comfortable at the kitchen fire, sits our friend Jehu, smoking and unconcerned. He coolly assured us that, as no car had yet come from Galway for us, he did not think it within his commission to look out for another. Fortunately another car was got, and we start again, after considerable detention; and just as we leave the village, the car from Galway, which should have arrived two hours ago, makes its appearance. The laggard "boy" returns without his fare, and we at length reach Galway about eight o'clock in the evening, drenched with rain.

Leaving Galway on the morning of 20th October, we proceeded on a tour round the head of the bay to 
the south of that town. Towards Oranmore, nearly all the land seemed well suited to tillage. It rises by a very gentle slope from a few feet above sea-level, and continues, as far as the eye can see inland, the same low-lying country. It is mostly dry land, on a subsoil of limestone gravel. The beach affords a supply of sea-weed, but not, apparently, in any great quantity, though it could be easily boated from other parts of the bay, where it is said to be more abundant. The line of railway to Dublin runs through this district, All the land here, even within a mile of the town, is susceptible of very great improvement; and some excellent greencrop farms could be had. The advantages of proximity to the town of Galway, the line of railway, and the beach, with a deep dry soil to work in, and a mild climate, are matters which every intelligent agriculturist will appreciate. About half a mile from Oranmore, I walked over several hundred acres of land of the same dry character-a good black earth, lying on limestone or limestone gravel. The country all round seemed much the same. In some places, the limestone rock comes so near the surface as to render tillage impossible; but, for grazing, this kind of land is sweet and nutritious, though, I should suspect, likely to suffer in a very dry summer. The fences are far too numerous, and very many must be removed to admit of extensive tillagefarming; but as there is little or no draining requisite, the removal of old fences and heaps of stones, and the rebuilding of new division walls, are the principal outlay necessary,-always excepting the building of farmhouses and steadings, of which there are few or none 
in most parts of this country. The good land has been greatly injured by the common plan of burning the surface for manure; so that, except where it has been lying long in grass, a farmer must calculate on a considerable outlay in manure to restore this soil to good condition. At present there are hundreds of acres of such land, within a mile of both sides of the line of railway, lying quite waste. Landlords would be glad to hear of tenants of capital; and such men could readily obtain plenty of farms here on very moderate terms. Near the sea, I am informed that it is sometimes difficult to get water for the stock in summer. The climate is very favourable for grass and green crops, and, where the soil has been brought into condition, the best bred short-horn cattle and Leicester sheep thrive upon it.

At Ardfry, within about two miles of Oranmore, I saw a large herd of short-horns and a fine flock of Leicesters in high condition. Ardfry is the mansion of Lord Wallscourt, who has a considerable tract of land along the bay. All this part is well worth the examination of farmers, and the country is quite peaceable. The land, when subsoiled and partially mixed with the subjacent limestone gravel, yields excellent green crops, grass, and wheat, and seems very favourable for carrots and mangold, and for cabbages.

Lord W allscourt's sudden death, last summer, put an end to an interesting experiment, which was going on here under the management of Mr Skilling, now professor of agriculture in the Queen's New College at Galway; a kind of partnership concern, in which land- 
lord and tenant supplied respectively the capital and skill, and mutually shared the profits or loss. The farm comprised 1500 acres of arable land, and was to be managed by Mr Skilling. Whichever party supplied the capital for stocking and working the farm, was first to receive five per cent, before any division of the proceeds was made. The whole proceeds remaining were to be divided into three parts, two of which went to $\mathrm{Mr}$ Skilling to pay labour and superintendence, and one to Lord Wallscourt for the use of his land. Neither party, it is said, found the arrangement a profitable one, as it was probably not long enough continued to allow the benefits of better farming to tell. This may account for the appearance of the grazing fields and green crops, which did' not indicate good or rich farming. The quality of the short-horn cattle and Leicester sheep was very good, but the numbers, for such an extent of land, inconsiderable.

Along the bay, to the west of Galway, the country is very rocky, but the abundant supply of sea-weed enables the cultivator to keep it in good condition. It is held in small farms, for which, as tillage, it is certainly best suited. Indeed, so stony is this part of the country, that it would be impossible to cultivate it profitably on a large scale, on account of the numerous obstructions. This, I am informed, is the character of all the land along the north side of the bay of Galway.

The town of Galway is situated at the head of the bay of that name, and on the river which discharges Lough Corrib into the sea. In old times, a considerable intercourse was kept up betwixt Spain and the 
west of Ireland, and Galway was the chief port for the Spanish trade. So far back as 1493, it was a town of considerable importance, the mayor of that day having been a Spanish merchant. At present it is suffering from the pressure on the surrounding country, and business of every kind is very dull. The streets are dirty, and masses of rubbish are suffered to obstruct the most crowded thoroughfares. Great numbers of pigs are allowed to roam about the streets, and you sometimes find the possession of the parement disputed with you by a lusty grunter. The square seems the chief point of attraction; and every now and then the air resounds with the shrill squeak ${ }^{\star}$ of some unlucky porker, smarting under the lash of an angry car-driver. A handsome building, on the west of the town, is just completed, for the occupation of the professors and students of the Queen's College.

It is said to be in contemplation to make this port the station of the American packets, as from Galway America can be reached in four days less than from any port in England; and this is a measure which, I think, might be expected to contribute in no inconsiderable degree to the resources of the country. But it will probably depend on the opening of the railway to Dublin, which, when completed, will add much to the importance of the place. There are several excellent flour-mills situated on the river, and an immense water-power still unused. This may some day attract the attention of the enterprising tourist, who, putting all adrantages together-cheap and short 
transit for the raw material from America, cheap and abundant water-power, cheap and plentiful supply of labour-will justly conclude that no place in the British islands offers a more favourable chance for success in the cotton manufacture than the town of Galway. 


\section{H A P T E R V.}

GORT-COUNTY OF CLARE-ENNIS-RIVER FERGUS- " CORCASE LANDS"DROMOLAND CASTLE-SIR LUCIUS O'BRIEN'S FARMS - BUNRATTY COURSE OF CROPPING AND AVERAGE PRODUCE-FALL IN RENTSKILTANON-COMPLAINTS OF NORTH COUNTRY FARMERS-PRESSURE OF RATES DRIVING TENANTS OF CAPITAL OUT OF THE COUNTRY-TULLARELIEF ROADS-SCARIFF-LOUGH DERG-KILLALOE-THE SHANNONMILTOWN MALBAY-COROFIN-KILRUSH.

Proceeding southwards from Galway, after passing Oranmore, the land continues for many miles of the same character, dry light land on a limestone rock or gravel. In some places the rock covers the ground to a very injurious extent. Within a few miles of Gort, the country improves, and some very good sheep-pastures and corn-lands are found here. Gort is a clean, well-built town. Soon after leaving it the fields become more bleak, until crossing into the county of Clare, where good grass-lands are passed through. The cultivated land along the road is everywhere badly managed. A tract of uninteresting, stony, limestone country is then traversed; the fields becoming more open again as we approach Ennis, the chief town of the county. This town is of considerable extent, and is prettily situated on the river Fergus, which is navigable to this point, by large boats, from the Shannon. The streets seemed narrow and old-fashioned, but there are 
many good shops in the town. A fine suite of new county buildings are just being completed, which will contribute much to the ornament of the place, though, if payable from the grand-jury cess, it may be doubted whether it was prudent at present to proceed on such a costly scale.

Proceeding southwards from Ennis, the country improves. The road crosses the Fergus at Clare, to which town the river is navigable by large vessels. Along both banks of this river to its junction with the Shannon, being a distance of eight or ten miles on each side, are fine tracts of rich alluvial land, called "corcases," * which yielded very high rents before the famine. These rich flats are banked off from the inroads of the tide, being in many places under high-water mark of spring-tides. Where they have been left in their natural state, they are exceedingly fertile, producing heavy crops of hay year after year, or carrying large stocks of sheep and cattle. They have been generally let in farms of considerable extent, and $£ 3,10$ s. per Irish acre, besides grand-jury cess, \&c., was no uncommon rent for a large farm. The custom of the tenants was to sublet certain portions to the farmers of the upper country for meadow, at rents varying from $£ 6$ to $£ 8$ an acre ; and being fettered by no restrictions in their management, other parts were con-acred for potatoes at even greater rents, the tenant afterwarts putting in the grain crop, and frequently selling it, with the straw, before cutting. In this way the actual tenant employed almost no labourers;

* "Corcase," in Ireland, seems to denote much the same kind of land as the "carse" of Scotland. 
and the resources of the farmers in the upper country failing with the potato failure, they were unable to take meadow, while the labouring class, of course, for the same cause, ceased to con-acre. The tenant, thrown on his own resources, had neither capital nor skill to meet this new order of things, and the distress and abandonment of farms is accordingly as great on some of these naturally rich lands as on the poorest. The land which had been con-acred is reverting to grass; but any farmer who has ever been accustomed to strong alluvial land, may guess to what a foul state it has been reduced by this most negligent and injudicious management. One acre of land so con-acred, and now reverting to grass, is not one-fourth the value, at this moment, of the land alongside of it, on which the rich old sward has remained unbroken. I am not partial to stringent covenants between landlord and tenant as to tillage, but there is not a point on which, in my opinion, landlords should be more strict than in guarding against the spoliation of their property, by the breaking up of these rich alluvial meadow-lands for a few years' temporary gain. No skilful tenant would wish to see it done.

Dromoland Castle, the residence of Sir Lucius O'Brien, lord-lieutenant of the county of Clare, is finely situated in an extensive park, a few miles south of Ennis, and about a mile to the east of the river Fergus. It is a very extensive and imposing mansion in the castellated form, built of dressed limestone in courses, massive and substantial. To the left of the mansion is a lake of considerable extent; and on a lower level, in 
the rear, are the stables and farm-buildings, commodious and well arranged, and hid from view by the overhanging woods; while, farther up, the extensive gardens are seen in successive terraces, crowned by a very picturesque cottage under the trees at the summit.

On 22d October I accompanied Sir Lucius in a walk over five or six of his farms in the neighbourhood of the castle. Two of these farms have excellent houses and farm-buildings, and are beautifully situated on the rich slopes overlooking the Fergus and the lower Shannon. They each possess a considerable tract of these rich "corcase " lands, attached to fine dry arable land, gently sloping up from them. All these farms are situated within a short distance of water-carriage on the Shannon, and about twelve miles from the city of Limerick. When left in its natural state, the land immediately rising from these flats is of the richest feeding quality - a deep, black, earthy soil-dry, and admirably adapted for grazing or green crops. One or two excellent farms are to be let here, which are well worth the examination of farmers.

On the opposite side of the Fergus is the farm of Island Magrath, which by many is considered one of the best farms in Ireland. It is extensive-between 300 and 400 Irish acres-and is at present to be let at a moderate rent; it is said, for something under 20 s. an English acre. It is the property of the Marquis of Conyngham.

From the river Fergus, along the north bank of the Shannon to Limerick, the country is all of this naturally fertile character. Passing the old ruined castle of Bunratty, which is beautifully situated close to the 
waters of the Shannon, the road traverses a very rich country. At Cratloe, four miles west of Limerick, the residence of Mr Augustus Stafford, M.P., which I subsequently visited, I learned from a respectable farmer, and a man of intelligence, that the usual mode of management in this country, is to keep all the tillageland in a constant succession of crops, and the land which is required for stock always in grass. The course followed is to take-

1. Green crop.

Wheat.

Oats or barley.
2. Green crop.

Oats or barley.

Oats;

then begin again, and so repeat the course : 300 stones of wheat to the Irish acre, equal to 70 imperial bushels, and 300 to 400 stones of barley, equal to 80 to 100 bushels, are said to be no uncommon crops. These are equivalents to 43 bushels of wheat, and 56 to 65 bushels of barley, per English acre, and must be regarded, under the present. mode of management, as indicating a soil of the highest fertility. Rents are falling rapidly in this quarter: one farm of fine quality, which used to let at $£ 2,10$ s., is now offered at $£ 1,5$ s. an Irish acre. Another of 300 acres, principally fine old grass, let to a dairy farmer at nine hundred guineas, has lately been reduced to six hundred.

Leaving Dromoland on 23d October, I proceeded eastward to Kiltanon, near Tulla, the residence of $\mathrm{Mr}$ Molony, which I reached in time to walk over part of his estate with him in the forenoon. He has judiciously improved some extent of bog-land, on which there was then growing a very luxuriant crop of swedes, white carrot, 
mangold, and cabbages. The swedes, indeed, were over-luxuriant, many of them having rotted. This may, perhaps, be attributed to over-manuring, causing a too rapid development of the plant in a bog soil, which had not been previously rendered sound by a sufficient admixture of sand or gravel. In the afternoon I accompanied two extensive north-country farmers over a different part of the estate, where were excellent crops of turnips, and large fields of well laid-out and wellsheltered pastures. These gentlemen have been farming extensively in this part of the country for some years back. They complained much of bad times, high rents and rates, and the difficulty of getting landlords to reduce rents, in any case where the tenant was solvent. They suffered much also from the thievish and indolent habits of the people, the sums paid by them for watching their crops and sheep stock amounting to a considerable tax on the produce. They also complained of the wasteful management of the elected poor-law guardians, who were often partners in the contracts for supplying the workhouses. They spoke highly, however, of the natural fertility of the soil, and the prospects of tenants of capital coming to the country and locating themselves judiciously. For such, they think, there is at present an excellent opening, as landlords are prepared to submit to lower rents, and definite arrangements could be made with them as to a limitation of poorrates and grand-jury cess.

The fears entertained by the more intelligent class of farmers as to the injury they are likely to suffer from the progressive increase of rates, are illustrated by the 
case of a tenant, on whose farm I was to-day, and which is now to be let. This man came to the country thirteen years ago, with not more than $£ 100$ of capital. His landlord lent him $£ 300$, and with this he contrived to stock and carry on a farm of 300 acres. He was very skilful in the management of sheep-stock, and introduced the best rams from England, with which he improved his own stock, and then sold their produce at high prices in the surrounding country. So well did this succeed, that in a few years he repaid his landlord the borrowed money, besides, at the same time, greatly increasing the numbers and quality of his farm-stock. The frightful increase of rates, with diminished prices of produce, alarmed him : he found the capital which he had accumulated by skill and industry slipping away; he could not get what he considered an adequate abatement of rent from his landlord, though the increase in his rates amounted to nearly a second rent; so, availing himself of the power of surrender, which is fortunately a clause introduced into most Irish leases, he determined to sell all off, and quit the country for New Zealand. After paying all his debt, he has retired with a capital of $£ 1000$, and his farm is abandoned to the landlord, who is now anxious to get a solvent tenant at a lower rent than, I am assured, this man would have gladly paid, and remained in the country. But how much does this single example teach! First, that the soil yields a grateful return to industry and skill ; second, that these are marred by the impolicy of placing the pressure of the rates exclusively on the tenant, (which is unhappily the law in Ireland,) thereby driving out of the country 
a prosperous, skilful farmer, whose example was of the utmost benefit in a district where these qualities are so deficient, but who felt himself compelled to remove his capital from the danger in which it stood of being absorbed in the general poverty of the country; and third, the short-sighted policy of the landlord, (too common, I lament to say, and mainly to be attributed to a want of that knowledge of the proper business of a landlord, to which I have already had occasion to refer,) in refusing to share the difficulties of the times with his tenant, because he was a solvent man,- - and the natural consequence of this in disgusting the tenant, who then abandoned the farm, for which its owner cannot now get a solvent tenant at the greatly reduced rent he is at length willing to accept for it.

In the neighbourhood of Tulla there are some good farms to be let, sound sheep-land, on the estate of $\mathrm{Mr}$ Molony of Kiltanon. I passed several of the roads to-day on which improvements had been begun, but never completed, at the time of the famine. Several of these had been left in a state which rendered them actually dangerous to the traveller, and others were quite useless to anybody.

From Tulla to Scariff and Lough Derg, the land is of various quality. Behind Scariff it rises to a considerable elevation, innumerable little patches of cultivation stretching up the mountain side, and encouraging the growth of a population which nothing but potato culture could keep in existence from the produce of such a soil as that on which they were located. The 
consequence has been a mass of pauperism, now overspreading the better part of the surrounding country, and threatening eventually to absorb the entire produce of the land embraced in this union.

The banks of Lough Derg are generally fertile and picturesque, there being many very eligible estates and farms in the extensive district between Portumna and Killaloe. A steamer plies regularly on the lake. From Tomgraney the road passes over a comparatively elevated district, between which and the Lough lies much improvable land, which is at present in a very neglected state. Descending the hill near Tinerana, the eye rests with pleasure on the neatly laid out and well-cultivated fields, interspersed with the woods, surrounding the mansion-house of that name, and stretching down to the margin of the lake. Winding along its shores, the road affords many beautiful views to the traveller of the fertile lands of Tipperary, rising from the opposite side of the lake, up the green slopes of the Arra mountains, beyond which may be also seen the tops of the Silvermine and Keeper. Near Killaloe stands an old fort, beautifully situated on a green mound commanding the entrance into Lough Derg, which is here gradually narrowed into the bed of the Shannon.

Proceeding southwards from Killaloe, the land on the road-side is generally inferior as far as O'Brien's Bridge, where, crossing the broad and beautiful river, you enter the county of Limerick. Along this fertile valley, the country is now rich and well wooded; the frowning ruins of ancient castles, and the "shining morning face" of modern mansions, equally 
bespeaking the good taste of their founders in their choice of a situation. Passing the demesne of Lord Clare, whose umbrageous woods shut out the river altogether, and proceeding a mile or two farther along fields of deep red friable soil, you reach the suburbs of the city of Limerick, where those who are curious in such matters may have an opportunity of inspecting, by dozens, some of the poorest and most wretched cottages in Ireland.

My time was too limited to admit of my visiting the western portion of the county of Clare, where I was informed that at Miltown Malbay very extensive and judicious improvements are going on. The district round Corofin, to the north-west of Ennis, is famed for its rich pastures. The south-west division, embracing the union of Kilrush, noted for its evictions and its poverty, is situated on the coal formation, (not usually favourable for agricultural enterprise ;) but the whole of the north bank of the Shannon, from Limerick to Kilrush, is well worth the inspection of persons in quest of land. 


\section{CHAPTER VI.}

THE CITY OF LIMERICK-ADARE-CROOM-EAST LOTHIAN FARMER-BRUFF -RENT OF LAND-PEOPLE GRATEFUL FOR EMPLOYMENT-LIMERICK TO TARBERT BY STEAMER - TARBEKT - MR BLACKER'S TILE AND POTTERY WORKS - COUNTRY ABOVE TARBERT - MR FITZGERALD'S PEAT-GLIN CASTLE-FOYNES-ASKEATON - CLARINA - TERVOEVIEW FROM CARRIGOGUNNIEL-RENTAL AND PRICE OF AN ESTATEWRETCHED HUTS.

THe city of Limerick (population 52,315) is situated ninety-two miles west of Dublin, and distant by railway 129 miles. It stands partly on an island in the Shannon, which is navigable by large ships to the town. The principal streets in the new part of the town are laid out in straight lines, with broad thoroughfares, and high, well-built brick houses, very much resembling the better streets of Dublin. There was a business-like appearance about the shops and people. The town itself stands low, but with its cathedral, bridges, and fine river, is not wanting in picturesque effect. For extent and population it is now the fourth town in Ireland. The shipping at the quays was not numerous. There are but two small steamers which ply from the port, and both are employed only in the summer, one being laid up during winter, as the other is found sufficient for the trade. These steamers ply down the river to Kilrush, calling off the ports on each side 
on their way. If any judgment may be formed of a place by its hotels, the stranger will speak well of Limerick - Cruise's being the best-managed hotel which I saw in Ireland.

On 25th October I proceeded on my tour through the county. To Adare the land is of fine quality, and much of it under tillage. The greater part of the country is on the limestone formation, generally of a flat character, and at a low elevation, with rounded hills and gentle slopes running through it. On the borders of Tipperary and Cork it is somewhat hilly; and on its western side, next Kerry, it lies on the coal formation, which gives a more elevated and colder country than the limestone.

In the neighbourhood of Adare is the farm of an East Lothian man, who came to Ireland thirty years ago. The land here is a fine deep red soil, open and friable. The country is well wooded, and warmlooking. This gentleman farms very extensively in this county, having another large farm of nearly 400 Irish $=640$ English acres, near Croom. Here he grows all the usually cultivated crops-wheat, barley, oats, turnips, \&c. On this farm he keeps a stock of forty large half-bred cows, rearing all their calves, which are crosses with the short-horn; making besides, from each cow, three firkins of butter, worth from 40 s. to 50 s. a firkin. His young stock are very good, the bull calves particularly large and fine. The soil of this farm is good sharp turnip-land, for which he pays a smart rent, running from 20s. to 30s. an English acre, besides poor-rate and grand-jury cess; and having been 
obliged, almost entirely at his own expense, to build the farm-steading, and to fence and drain the farm. The advantage of having these preliminary improvements executed by the landlord, is seldom sufficiently appreciated by a tenant.

Proceeding eastward from Croom to Bruff, the country improves, the soil being generally a deep red earth, with loose limestone pebbles through it. For miles around Bruff it is of very superior quality. Rising from the flatter lands are rounded hills of grass, at present clothed with such verdure as to be mistaken by one at a distance for turnip-fields. It continues the same character, till within four or five miles from Limerick-a beautiful rich country, capable, under good management, of as much productiveness as the best lands in East Lothian. Nearer Limerick the land is not of the same high character, but a very fit subject for remunerative outlay of capital, especially considering its vicinity to a populous city and the terminus of a railway by which Dublin may be reached in four or five hours. Dung, in any quantity, may be got in Limerick, for 1s. per load of 20 to $30 \mathrm{cwt}$.

In all this rich tract of country, upwards of forty miles of which I traversed to-day, there is no attempt at anything like high farming. Bone-dust and guano, as auxiliaries to the farmyard manure, are scarcely tried; and feeding with linseed-cake, beans, or other imported food, quite unknown. The rent and rates of the best land, as now reduced, may be stated at 30 s. per English acre; but there are no sufficient farm buildings in the country, and landlords, generally, have 
not the means to make them. If, with these disadvantages, and the generally bad system of cultivation practised, this rent can be made from the land, how much more beneficial would it be to the community, and how much more profitable to a man who had sufficient skill and capital thoroughly to develop its capabilities! But where is that man to come from, so long as landlords are unable to provide the permanent accommodations which are necessary? and what hope is there for the country, so long as any laws exist which obstruct the transfer of the land to those who are able to perform effectively the proper duties of landlords? I am assured by Mr Christie, who has been long in the country, that the people are well-disposed, and very grateful for employment.

Leaving Limerick next morning, I proceeded, by steamer, down the river to Tarbert, a distance of thirtytwo miles. The sail down the river is most interesting, both banks being rich and fertile, and ornamented with mansions surrounded by fine wood. Here and there a church-spire peeps modestly from among the trees, while on both sides are seen the ruins of ancient castles perched on the summit of a lofty rock, as Carrigogunniel; or more picturesquely situated on the water's edge, like Bunratty. The ruins of old castles, abbeys, and churches are so numerous, as to lead one to suppose that, in former times, this country had been in a much more prosperous state than it is at present. From Limerick to Tarbert, on the south bank of the river, there are not fewer than twenty of such ruins; and on the north bank nearly as many, castles and churches 
being in about equal numbers. Many green islands are passed near to the mouth of the Fergus river.

At Cahiracon, on the north bank, the coast becomes bold and wooded, and, with a west wind blowing strong, we here experienced some of the pulsations of the Atlantic. This is a very picturesque spot, and one can fancy that the time may come when the wealthy citizens of Limerick will have their villas along this shore for sea-bathing and summer residences. Foynes island, on the opposite side, with its wooded eastern shore, seemed equally eligible for this purpose. Leaving the low limestone district at Foynes, the country becomes more elevated; Mount Trenchard, the residence of Lord Monteagle, embosomed in wood, being passed on the left. Except two large ships, close to Limerick, and two brigs about half-way down, we did not see another vessel till we came to Tarbert, where a few small coasting brigs were waiting for a wind. Twenty years, we may hope, will tell a different tale; and that this magnificent river, washing a country far more extensive in fertile land than the Clyde, will bear on its waters a hive of busy steamers and noble merchantmen.

Tarbert is a small seaport town in the north of Kerry, situated on an estuary of the Shannon, and close to the western boundary of the county of Limerick. There are two extensive grain stores here, the property of wealthy corn merchants, which are always open for the purchase of grain from the farmers in the surrounding country. Not far from the village, a tile-work has been erected by Mr St John Blacker, a gentleman who 
has exerted himself greatly in this neighbourhood to meet the distress by giving increased employment. In one electoral division in which he has property, he employed three to four hundred men, with the view of keeping down the necessity for out-door relief, but without any perceptible effect, as the rates in that division now amount to $12 \mathrm{~s} .4 \mathrm{~d}$. in the pound.

At $\mathrm{Mr}$ Blacker's tile-work, pipe-tiles of the best quality are made - as good an article as any one could wish to see. The selling price is $15 \mathrm{~s}$. per thousand for inch-pipes. The pipes are glazed by a simple process, which may add to the durability, but perhaps does not improve the permeability of the tile. The porous character of the unglazed pipe permits the access of water through its substance as well as at its joints, and, of course, in that way, assists the action of the drain. $\mathrm{Mr}$ Blacker has also established a pottery-work here. The clay seems of fine quality for the different purposes to which it is applied.

About 2 miles inland from Tarbert, the country rises to an elevation of five or six hundred feet above sealevel, and a great tract of good strong land is here met with. It is susceptible of much improvement by drainage and fencing, but I should fear the climate-so near the Atlantic, and at this elevation-is too moist for grain crops. The dairy farming of the upper parts of Ayrshire might probably be introduced with success. Whether the thievish propensities of the natives is greater than usual here, I cannot say; but the bailiff on an improved farm which I visited is an old soldier, and pointed out, with much satisfaction, the masterly arrangement of his corn- 
stacks, so placed that he could command each one of them with a gun from his bed-room window!

On the Rev. Mr Fitzgerald's estate here, there is a peat of a hard and compact quality, almost approaching to the nature of coal. It is said to be prolific of gas, and had been tried with much success, in one of the Queen's steamers, for fuel. This gentleman has exerted himself much to encourage the people in habits of industry.

Returning towards Limerick by land, we pass Glin Castle, a very handsome edifice on the shore, near the village of that name, with a good deal of wood round it, and the fields along the sea-side very improvable. The farmers are said not to be in a prosperous condition, and certainly the appearance of the land indicated something wrong. But it is capable of very great improvement, and its situation, a few feet above the level of the waters of the Shannon, makes it a pleasant and desirable locality. A few miles farther east, we pass the grounds of Mount Trenchard; shortly after which the road descends into the low-lying limestone district at Foynes, through which it proceeds to the river Deel at Askeaton, where are the ruins of an ancient castle of the Desmond family; and farther down, the very common accompaniment of an old castle in this country -the ruins of an abbey. For the next eight miles the land continues of the same character, light green-crop soil on limestone, capable of much improvement under a better system of management. As we approach the river Maig, a tributary of the Shannon, we cross some of the rich "corcase lands," and rising out of these are 
gentle hills of excellent tillage-land. At Clarina, Carrigogunniel, and Tervoe, the country is very fertile,deep red earth when turned up by the plough, and the finest pastures when in grass.

At Tervoe, the residence of Mr Monsell, M.P., a large party were assembled, including Mr Horsman, M.P., Mr Augustus Stafford, M.P., Mr De Vere, and others. This house is beautifully situated on a lofty bank about half-a-mile from the Shannon, in a finely wooded country, and commands a view of the shipping and the water up to the city of Limerick. The walks and drives in the grounds are varied and extensive; the land is mostly in pasture of the finest quality.

Within a mile of Tervoe stands the ancient castle of Carrigogunniel, finely situated on the summit of a mound of trap rock, protruding through the limestone, and rising to a height of nearly 200 feet from its base. Entering through the breach made by the soldiers of Cromwell, and ascending the stairs of the last remaining tower, we beheld a prospect which is beyond all things rich and beautiful. The day was sunny and warm, the grass of the rock on which the castle stands of a refreshing green, the same verdure continued for more than a mile over the fat "corcase" land to the river : the noble Shannon gleaming in the sun, and seen from the spot on which we stood, winding its way for miles through the fertile country; one or two large ships floating up with the rising tide, their white sails hanging loose in the still air : on the farther side of the river, the same rich land rising, through Cratloe woods, into a lofty background; to the east, the city of Limerick overhung by smoke, 
behind it the Keeper mountains of Tipperary ; to the south, a background of hills dividing Limerick from Cork; and between them and us, and beneath us, miles and miles of a rich wooded country - the whole presenting a scene of natural fertility and beauty which can scarcely be surpassed. With a change of names, the words of Scott describe this scene,-

“The wandering eje could o'er it go,

And mark the distant city glow

With gloomy splendour red;

For on the smoke-wreaths, huge and slow,

That round her sable turrets flow,

The noonday beams were shed,

And tinged them with a lustre proud,

Like that which streaks a thunder-cloud.

"While eastward far, with purer blaze,

On Keeper mountains fell the rays,

And as each heathy top they kissed,

It gleamed a purple amethyst.

Yonder the shom of Clare you viewed,

Bunratty's walls, and Cratloe's wood ;

And, broad, beneath us roll'd,

The Shannon's stream, the eye might note,

Whose islands on its bosom float

Like emeralds chased in gold."

Leaving this beautiful scene, we walked down into the country, to examine it more narrowly. The richest verdure clothes the field where nature has been allowed to do her work unheeded. Weeds and thistles are the unfailing accompaniment of a tillage, guided by the reckless necessity without the industry of man; and here the rich soil covers itself luxuriantly with these, as soon as the careless cultivator removes his scanty crop and leaves the land to nature for the winter.

Below Carrigogunniel there is for sale a very valuable farm of 740 English acres. Three-fourths of it is 
"corcase" land, said to be capable of producing, in its natural state, 7 tons of hay to the Irish acre. The rest is dry tillage-land of the best quality. It is held on a lease for ever, at a rent of about 14s. an Irish acre, and will be sold subject to this rent and the other conditions of that lease, besides a jointure of $£ 92$ payable to a lady aged 70. The yearly rents and tithe rent-charge paid by the present holder are stated to be $\begin{array}{llll} & £ 1374 & 9 & 8\end{array}$ The head rent $£ 326,15 \mathrm{~s}$. 5d, and receiver's fees, $£ 8,3$ s. 5 d., $\quad$. . . . $\quad 3341810$

Nett yearly profit, as stated by the adver-

tisement, . . . . . . . £1039 1010

$£ 18,000$ was offered for this estate some years ago, but not accepted; and $£ 10,000$ was offered last year, and again refused. It is said this sum would now be taken. Adding 5s. per pound for poor rate and county cess, the present rent averages $46 \mathrm{~s}$. an English acre, or about $£ 3,14$ s. an Irish acre: which seems high, but the land is very good.

Walking to an adjoining height, we clambered over a wall, and found ourselves in the centre of a cluster of miserable huts, which the owner of the land permitted the people to build on rent-free. The space occupied might be about a quarter of an acre in extent, the summit of a trap rock, without a particle of earth on it, or any regetation except what floated in the green stagnant pools in the crevices of the rock, and before the doors, or grew luxuriantly on the damp thatch of the roofs. On this spot were huddled together about a dozen huts, several of which we entered. Some of them were occu- 
pied by old women living by themselves, others by families : they had no gardens of any kind, and said they could get no work ; and, if this was true, they must exist either on out-door relief, or by plundering their neighbours. They expressed themselves as very thankful to the owner of the land for the privilege of occupying this barren rock!

It was the only barren spot I saw in this very fertile neighbourhood. From this point to the river runs a ridge of fine dry land, about a mile in length, with rich "corcases" on each side of it, having river frontage, and a road to the water-edge. It would make a farm of the most valuable description. In the "good times," the best of the land let at about 44s. per English acre. It is within four or five miles of Limerick. 


\section{CHAPTER VII.}

CASTLETON-RATES-DESEKTED LAND-AUXILIARY POOR-HOUSE-SCHOOL -ONE MODE OF BECOMING A FARMER-MR COX'S FARM-SIR D. ROCHE'S FARM, ITS ADVANTAGES-CAHERASS-ADARE MANOR-RATHKEALE-NEWCASTLE-LORD DEVON'S ESTATES-ADYANTAGE OF A RESIDENT AGENT WHO UNDERSTANDS HIS BUSINESS-BENEFICIAL ARRANGEMENT WITH TENANTS, AND SATISFACTORY RESULT-SPRINGFIELD CASTLE-INSTANCE OF PERTILITY-CHARLEVILLE-CASTle OLIVER-DESCRIPTION OF COUNTRY-KILMALLOCK TO LIMERICK CRATLOE.

ON the morning of 29th October, $\mathrm{Mr}$ Monsell, $\mathrm{Mr}$ Horsman, Mr Barry, and I, started early for a long drive through the country, proceeding to Castletown, within a mile or two of the southern boundary of the county. In this union, out of an area of 4900 acres, 2500 are "waste," neither producing anything nor paying any poor-rate. The rates and county cess amount to 21 s. 6 d. per pound, and another rate will be required before the end of the year. This was not mountain land nor bog, but an extensive open plain of good sound land, deserted by the landlord, the tenants having fled to escape the ruin of indefinite rates, and the labourers being driven to the workhouse to avoid starvation. Here the process of changing owners was going rapidly on, inasmuch as one mansion-house is already occupied as an auxiliary poor-house by 340 pauper women. 
A melancholy sight it was, to stand looking from one of the drawing-room windows of that house and witness the sad scene. In front was what had once been a handsome pond, with a little island on which still stood a rather rickety statue; beyond this a fine park with old timber, and immediately below, on the gravel, were squatted a great number of women, wearing out the day by picking grass from among the stones. Within the room other women were spinning, some picking oakum, many doing nothing at all. The house was quite full, and very clean and well managed. More than twothirds of the females were young girls and women, healthy and intelligent-looking, who would be a great acquisition to some of our Australian colonies. Many of them looked very happy, but others were weeping. It was a sad sight altogether.

On Mr Monsell's property here we visited a school, which is divided into two apartments, one for girls, and the other for boys. There might be fifty of each, the children of the neighbouring small farmers. They were clean and neatly dressed, and showed much proficiency in geography, reading, writing, and arithmetic, in all of which we witnessed their examination. The school is under the superintendence of the priest of the parish, and the children do much credit to their teacher, who takes his instructions from the priest.

Crossing some high land, we again descended into a valley, where we drove through a well-wooded and picturesque demesne, surrounding a handsome mansion. The stables and coach-houses, \&c., commodious and extensive. Two cows were wading in the long rich grass, 
which would have pastured twenty. But things had gone wrong here too; rates were in arrear, and rents unpaid ; and at that moment a watch was kept on the road to give timeous warning of the rate-collector's approach, so that the cows might be hid out of sight for fear of seizure.

Very few of the farmers here begin with any capital. When a man manages to sare $£ 100$ or $£ 200$, he goes to a landlord and offers a certain rent for a farm, backing his offer with all the capital he has, as a douceur or fine in hand, to induce the landlord to accept his terms. The offer is accepted and the fine paid. Having thus exhausted his capital, the tenant then advertises that on the following Sunday he will set out a certain field for potatoes. Several hundred people assemble, and each marks out the piece he wishes to have. A rent is fixed for it, probably $£ 10$ an acre; one-third of which must be paid before breaking the ground, and the other twothirds before removing the crop. The tenant thus gets all his rent out of perhaps the fifth part of his holding. The same thing is repeated, on the same field, a second and sometimes a third year, after which the tenant takes two or three crops of oats, and then lets the land "rest" to recover itself. This process is pursued with other parts of the land till all is gone over, by which time the first is ready to begin upon again. The money paid in advance, by the potato-renters, enables the farmer, with what credit he possesses, to stock the rest of his land, and in this way he manages to carry on without capital. But the potato failure put an end to this rotten system; and the tenant who depended on it, and the landlord 
who was enriched by it while it lasted, are now equally helpless.

On our return, we visited the extensive farm of $\mathrm{Mr}$ John Cox, inspector of drainage for the county, where we saw excellent green crops and sown grasses. Everything here betokened good and careful management. This farm is held on a long lease, at a smart rent; every improvement has been done by the tenanthouses, fences, and drains-entirely at his own expense. The rates and taxes have increased, since the lease was entered into, till they are now a second rent; but the landlord will give no abatement, and altogether refuses to relieve the tenant from any part of the unforeseen and ruinous rates to which the distress of the country has subjected him; thus taking advantage of the capital and labour which have been expended by the tenant, in improving the farm, to hold him to a bargain which he would otherwise have been too happy to surrender. What a melancholy contrast to the liberal system and mutual confidence which ought everywhere to prerail between landlord and tenant, and how ruinously opposed to the true interests of both, and the general improvement of the country!

On the morning of 30 th October, accompanied by Mr Cox, I left Tervoe to examine a farm of Sir David Roche's, about two and a half miles to the west of Limerick. It consists of 300 Irish acres (485 English) of fine dry red land, laid out into large fields, with an excellent dwelling-house, and extensive, well-arranged farm-buildings. It is adapted for all the usually cultivated crops, and particularly good for grazing. The 
proximity to Limerick will enable the tenant to draw three loads a-day of manure from town with the same horses, paying only 1s. a load of $30 \mathrm{cwt}$. for the manure. It, of course, has the same facility for getting away produce. The farm is all in the proprietor's hands; no one will be dispossessed, and a favourable entry would be given to a suitable tenant. It has been farmed for some years by Sir David, and no expense spared to put it in good order. It will be let on lease for $£ 2,5$ s. an Irish acre, (about 28s. an English acre,) the tenant being freed from all rates and taxes. The people are quiet and well disposed ; of this I am assured by Mr Irvine, the bailiff, who is a Scotchman. I can very strongly recommend this farm as being well worth the attention of a tenant with adequate capital. Such a man could not fail to make it answer, as there is no risk of his being swamped by an indefinite increase of taxation.

At Caherass we breakfasted with Sir David Roche, who is carrying on extensive improvements, judiciously, on his estate, besides working large flour-mills on the river Maig.

From Caherass, the land is pretty good, to Adare Manor, the residence of the Earl of Dunraven. The ruins of seven abbeys in this demesne are both singular and interesting; and combined with the beautiful scenery of the park, every part of which is marked by admirable good taste, are highly picturesque. The castle, a modern building, stands on the left bank of the river Maig. It has been nearly all built under the direction, and by the plans, of its noble owner; and 
presents, in every part of it, evidence of the perfection to which Irish artificers can attain. The carving of the stone of the outer walls, cornices, and balconies-of the chimney-pieces, and the oak-work throughout the entrance-hall-but beyond all, of the noble picture gallery, 180 feet in length, is exquisitely wrought. The stone, marble, and oak, are the produce of the estate; and I was informed by Lord Dunraven, that the work was all done by natives of the place. Beneath the windows of Lady Dunraven's boudoir, a beautiful apartment, the river is seen gently flowing through green slopes which are clothed with fine trees, and stretch away through the extensive demesne.

Continuing our journey westward to Rathkeale, we passed much good tillage-land. From Rathkeale to Newcastle it is still better. All this tract forms a good field for enterprise-deep dry land, capable of producing all kinds of usually cultivated crops.

At Newcastle I was introduced to $\mathrm{Mr}$ Curling, an English gentleman, who is resident agent on the extensive estates of Lord Devon. It was quite refreshing to hear him speak hopefully of the country. His plan to meet the difficulties of the time was agreed to by the trustees on this estate, and it was as follows: He found, when he succeeded to the agency, that it had been usual to give notices to quit, to every tenant on the estate every year, and that all arrears had been carried forward against the tenants, however old standing these arrears might be, many of them, indeed, being the arrears of the predecessor of the tenant in possession. This state of things prevented all exertion, as a 
man never was sure that he would be allowed to reap the reward of his own industry, and he might fear that his accumulated arrears would be exacted if he exhibited any signs of prosperity. The notices to quit were put an end to ; but in forgiving arrears it was necessary to discriminate betwixt good and bad tenants ; and it was therefore resolved to wipe off all arrears up to 1846 , thus placing the man who had paid his rent punctually for the last two years, in a better position than the defaulter for the same time. It was also necessary to re-value the whole estate, some farms being let too high, others too low. This was done by Mr Curling, and he gave this new valuation a retrospective effect. The rental of the previous year, 1848, was charged on the new valuation, and all rent which had been paid beyond that amount was returned. The effect of this return of money to the tenants was surprising. Those who had not paid even the new valuation last year, are now called upon peremptorily to do so; but the arrear of the previous two years, where such exists, is divided by instalments over several years. The effect of all this is, that while other landlords are getting scarcely any rent, $\mathrm{Mr}$ Curling is collecting nearly his whole rental, and a good portion of this arrear. His new valuation was calculated on a certain price for butter, (which is the chief produce of this dairy district,) and that being much higher than this year's price, a farther corresponding deduction, for the time, is made on each man's rent. Not one of the tenants are leaving, and $\mathrm{Mr}$ Curling hopes to bring the estate safely through all the difficulties of the time, especially 
as the subdivision of the Unions will now bring it, in so far as regards the poor-law, entirely within his control.

How much may be effected by an agent who understands his business thoroughly, and acts with manly honesty between the tenants and their landlords! How different would the state of the country be now if there had been many agents like $\mathrm{Mr}$ Curling, and many proprietors like Lord Devon's Trustees, who could appreciate the value of such an agent, and give scope to his plans!

This estate is principally occupied by small dairy farmers, much of the land being of a stiff, retentive nature, and not well adapted for tillage. The farmers being thus more dependent on dairy produce than crop, they are not so much affected by the fall in the prices of grain, and the estate will no doubt be more easily brought through, than one where returns from tillage only were trusted to.

A flat country, with an undeviating straight line of road, ten miles long, brought us to Springfield castle, where we were very hospitably received by Lord Muskerry. It is all strong good land, principally in grass, and much in need of drainage. The quality of the soil at Lord Muskerry's may be judged of from the following treatment of a field by a tenant, as related to me by his lordship. It was con-acred twice in succession with potatoes, neither time receiving any manure; it was then cropped with two successive crops of wheat; after which, with seven successive crops of oats, all good - the last said to be a splendid crop. The land was then 
left to nature, without a particle of grass-seed, and in three years it became, and now is, very fine feeding land ! A farm of 300 acres is now to be let by Lord Muskerry. Springfield castle is a fine old place, with some good timber, and a busy noisy rookery, the only one I remember to have yet seen in the west of Ireland.

Next morning, October 31st, we left Springfield castle, returning eastward along the borders of Cork and Limerick, by Drumcollogher and Charleville, to Castle Oliver and Kilmallock. Charleville, a station on the Dublin and Cork Railway, is a nicely situated town, with a very handsome new church. A good deal of bustle and some business was going on in the principal street. On the steps of the market-house about twenty women were seated, each with large wooden pailfuls of butter-milk for sale. Several cart-loads of fine large apples were also on sale, and four loads of turf, for which two shillings each were asked, the distance to the "mountain" being considerable. Several woolpacks and carts with furniture were passing through the town. Nearly every fourth shop was shut up from want of trade.

At Castle Oliver, important improvements are being effected by the Misses Gascoigne, who have planted, drained, and improved their property to a very considerable extent. I may give an interesting quotation from the report of Mr Cox, Inspector of Drainage, from the seventeenth report of the Board of Public Works. He says, — "Many old prejudices have given way, and particularly that generally entertained against deep-draining, as compared to shallow. In 
illustration, I may mention that upon the property of the Misses Gascoigne, (where the most extensive works of land improvement in the county of Limerick are being executed,) some of the occupiers were so opposed to what they designated spoiling their land by making deep useless holes, that they have been known to use pitchforks in driving away the overseer who ventured to commence such works on their lands; but so differently do they now feel, that they make anxious applications to have their lands included in the drainage operations." The Misses Gascoigne have erected a flax-mill to encourage the flax culture, and a tile-work, at which oneinch pipes are sold at 12s. per thousand.

The valley through part of which this day's ride led us, extends to near Cahir in Tipperary, a distance from Newcastle of about forty miles. The breadth of the valley is from six to nine miles. It improves towards Tipperary, and then becomes what is known as the "Golden Vein." There are few such tracts of land in any country, all of it being soil of good quality, and very much of it the primest feeding land. Notwithstanding this, many farmers are surrendering their leases and going off to America, on account of the twofold action of depressed prices and increasing rates. The railway from Cork to Dublin traverses a great part of this valley. We joined it at Kilmallock, where one of those common but heartrending scenes of an emigrant-parting was witnessed. A dozen men and women, with children, were about to bid adieu to their relatives, before parting with them for ever to go to America. Strong men were embracing each other, and sobbing aloud; while women, with more 
unrestrained grief, gave way to the feelings which almost overpowered them.

From Kilmallock by railway to Limerick, a continuous line of fine country is passed through, stretching into Tipperary, and then bending back into Limerick. This land is chiefly in grass, and by no means in an exhausted condition. But all careful management is unknown. Fences, if they may be called so, of low turf walls, very numerous and insufficient, and no farm-offices whatever.

The same afternoon I proceeded to Cratloe, the residence of Mr Augustus Stafford, M.P., four miles west of Limerick, on the north bank of the Shannon. Along this road the land is very fine, and fairly managed. A remarkable instance of the advantage of a workhouse test was mentioned here, in the case of the two electoral divisions of Limerick and Bunratty. The former has a larger population and smaller rental than the latter, yet the rates of the latter are one-third greater than the former. Limerick possesses ample workhouse accommodation, and has never admitted out-door relief to the able-bodied; Bunratty has not sufficient accommodation, and, being obliged to give out-door relief, there is no sufficient check on the increase of that ruinous system. 


\section{CHA P TER VIII}

CRATLOE-MOUNT TRENCHARD-LORD MONTEAGLE'S ESTATE-FOYNES HARBOUR-MODEL FARM-AGRARIAN OUTRAGE-TARBERT TO LISTOWELTURF TRAFFIC-STATE OF THE PEOPLE-HOPES OF THE LANDLORDSTRALEE-CASTLE ISLAND-MR HERBERT'S ESTATES-KILLARNEY.

ON a fine morning, on the 1st of November, I left Cratloe early, after enjoying a walk with Mr Stafford. A heavy mist hung over the river, which fortunately cleared up in time to enable the boatmen to see the steamer as she came down. I got on board, and, after a couple of hours' sail, was landed at Cahiracon, the wooded coast opposite Foynes, already mentioned. Here I engaged the boatmen to take me across to Mount Trenchard, the residence of Lord Monteagle. But we had to wait about ten minutes before starting, till one of them secured from his house a blazing peat with which to light their pipes. This was brought into the boat, and stowed away in the bow for use when required. The sail being set, all hands turned to and got their pipes in order, and so, calmly enjoying the sail, we swept along. How odd that such inveterate smokers have not yet learned the ease and economy of the simplest box of matches!

I arrived at Mount Trenchard in good time for a 
walk orer part of Lord Monteagle's estate with his lordship and Mr Stephen De Vere. That part on which the mansion is built, and the country behind it, is a slate-clay, interspersed with iron and culm, but neither yet found in sufficient quantity to repay the expense of working them. The land here rises rapidly from the sea-level to a height of 350 feet, a few fields above the house. About two miles to the east, we descend into the limestone country at Foynes, where an excellent deep-water harbour is being constructed, at the joint expense of Lord Monteagle and the Government. Lord Monteagle contributes $£ 4500$, the half of the estimated expense, and the Government complete the work at their own risk. The tolls to be levied are to be applied exclusively in keeping the harbour in repair. This port will form a most convenient outlet for an extensive agricultural district to the south of the Shannon, and will bring into play one of the best limestone quarries I have seen, which is not more than half-a-mile from the harbour. From the regular stratification of the rock here, blocks and slabs of any thickness and size can be got, suitable for the various purposes of building and pavement. The opposite coast of Clare, and the north of Kerry, are entirely deficient in lime, which is an excellent manure for soils on slate clay, and which may now be conveniently supplied from this quarry.

The island of Foynes, immediately opposite the harbour, is fertile, chiefly in fine old grass, and, containing several hundred acres, would make an excellent farm. The east side is wooded and picturesque, and the locality very desirable. Sea-weed and calcareous sand, as 
well as alluvial sludge, can be had in great quantity on its shores. The adjoining farms on the mainland also belong to Lord Monteagle, and are principally rich dry feeding-ground, with some alluvial flats partially flooded by the tide.

Leaving the flat limestone land and returning over the hill, after passing one of Lord Monteagle's schools, we found ourselves again on the slate-clay, on which there is here strong grassy land, capable of much improvement by draining. We saw some well-executed drainage work on the home farm, and looked at the ground where it is purposed to plant a model farm of 30 acres. The land is of fair quality, and not being better than the average, will of course form a fairer criterion for comparison to the surrounding farmers. It is about 350 feet above sea-level, and will be managed by $\mathrm{Mr}$ Conner, a Templemoyle scholar, part of whose duty will be to instruct in agriculture, on two days of each week, the scholars of three neighbouring national schools. Lord Monteagle showed me the plan of farm-buildings, with school-room, master's house, \&c., as sent down by the Commissioners of Education. It seemed wellarranged, but I should think much too costly. The estimate amounted to a sum which is more than the value of the fee-simple of the 30 acres to be accommodated by it. It includes, however, dormitories for apprentice pupils, a lecture-room, \&c., and is intended to afford examples of different modes of dealing with stock and tillage. A less expensive description of building would, in my opinion, be equally useful.

We visited Mr Sharp, Lord Monteagle's steward, a 
Perthshire man, who was dreadfully mangled by a set of ruffians here a few months ago. These men were hired by a person on the estate, who had taken offence at Mr Sharp for nothing more serious than this-viz. : This man, having had the privilege of helping himself to fodder and turnips for his cows from Lord Monteagle's yard, unavoidably caused a waste, to stop which the steward required that the cows should be fed at the same time, and in the same way, with the others on the farm. In revenge for this very proper and reasonable arrangement, one Sunday forenoon, as he was preparing to go to church, a party of ruffians entered the house, and cut and wounded poor Sharp most shamefully; it having afterwards appeared, in the evidence on the trial, that their instructions were to give him a "beating," and, above all, to cut him about the legs, so that he might be ever afterwards unfitted for the office of a steward. The scoundrels were got, and eleven of them transported; but poor Mr Sharp will never recover, perhaps not long survive, this brutal and dastardly attack.*

I cannot forbear mentioning the noble conduct of $\mathrm{Mr}$ Stephen De Vere, as related to me by Lord Monteagle. A large body of the tenants of Sir Aubrey De Vere, foreseeing the calamity likely to fall on them from the effects of the famine, resolved to emigrate to North America. To guard them against the wretched treatment to which they were then exposed on the royage, this young gentleman accompanied his father's tenants, taking a steerage berth, and sharing in their privations.

\footnotetext{
* For statement of Agrarian Outrages, see Appendix, No. 7.
} 
The ferer broke out on board; he tended the sick, and caught the fever himself, from which, after being in great danger, he fortunately recovered. After landing the people, he accompanied them up the country, remained with them till they were fairly set a-going, and then returned home.

Leaving Mount Trenchard next morning, I proceeded through Kerry to Tralee. From Tarbert to Listowel the country is high, bleak, and unpromising. There are numerous huts along the road on the edge of the bog, and from these an active traffic was going on, by men carrying loads of turf on their backs to Tarbert for sale. Each load at present brings only a halfpenny. The poor creatures manage to go two or three times a day, according to their distance from town, bringing back Indian meal with their money. Such a traffic as this would not be persisted in if the people had any wish to go to the workhouse. I was told by a man who had been an inmate of it for some time, that the food is sometimes insufficiently cooked, and too small a quantity given, and that they all would rather be half-starved at home than enter its walls.

At Listowel the river Feale is crossed by a handsome bridge, and the valley of the river is fertile and picturesque, though miserably cultivated. The good land continues for some miles further towards Tralee, when the road again ascends into bleak bog. Within about two miles of Tralee a great traffic was being carried on from the bog, by donkeys in carts and with panniers, and by people-men, women, girls, and boys-all carrying burdens of turf on their backs to the market. Here 
the demand being greater, somewhat better prices are realised than at Tarbert, a donkey-load bringing $6 \mathrm{~d}$. to $8 \mathrm{~d}$., and a back-load $1 \mathrm{~d}$. to $2 \mathrm{~d}$. The landlords are said to realise considerable rents from bogs well situated for roads and markets.

In all the line of country I came through to-day, some thirty miles in extent, I passed only one comfortable rick-yard, and moderately respectable live stock. At one place on the estate of $\mathrm{Mr}$ Crosby of Ardfert, some draining and enclosing was going on; but with these exceptions there seemed no industry whatever, other than the traffickers in turf. Improvements, I was told, are going on at some distance from, and out of sight of, the mail-road.

That the people in this part of Kerry are suffering most sererely from the consequences of the famine, no one can doubt who travels along the road. I was told by a very intelligent person connected with the constabulary, that in going through the country to make out their annual returns of the cultivated crops, for the information of Government, they find the greatest difference in the state of the people, as compared with what it was three or four years ago. Houses that were then comfortably furnished and provisioned, they find now with not more than a single chair, and bereft of the most common articles of furniture; while, in the matter of provisions, the people are reduced to the very humblest fare, living on turnips as their principal food. The children, who followed the car to beg, had generally rather a healthy and cheerful appearance; though now and then one saw the pinched features and crouched 
form of some one in the group, whose smileless face bespoke the famine through which they had all passed. The desire for emigration, in this quarter, among the labouring classes is universal ; and the sums of money sent back by emigrants to their friends, show how anxiously they urge them to follow. I was assured that one person, who had gone out to New York only six months ago, had already sent home to his friends $£ 10$, which was received at the post-office the day before I passed through Tarbert. The people look to America as their home-Ireland as no longer theirs.

Conversing with a land-agent I met at Tralee, I find that many landlords here are looking to the revival of the potato as their chief hope of better times. They are willing to reduce rents fifty per cent, and bear a proportion of rates, but only for a time, till the crisis is got over.

Tralee is a good town, with considerable trade, and several handsome streets. It is connected with the sea by a ship-canal, about a couple of miles in length. The surrounding country is low-lying and fertile. To the south it is wooded, and interspersed with villas, the view from which to the sea, and the magnificent mountain range to the west, running up from the water nearly 3000 feet high, is very fine. From the canal the land rises in gentle slopes, laid out in goodsized fields of excellent soil. For several miles along the coast the land is very superior, and great quantities of sea-weed and calcareous sand are found on it. The good quality of the land, and the command of seaweed, \&c., enable the tenants to get on better here than 
in most other parts of the country. Rents are said to be high, but I was not able to learn with precision what they really are.

From Tralee to Castle-island the land is in some places excellent, the best of it being supposed to be a continuation of the "golden vein" of Tipperary. It is all a highly improvable district, with abundance of limestone and turf.

At Castle-island I again met MrHerbert, M.P., and accompanied him over several farms in that neighbourhood. Much of the land here is in grass, and none of it appears to have been racked by the tenants. Several very superior farms would be let here, ten miles from Tralee and an equal distance from Killarney. Mr Herbert has for some years back been pursuing a course of improvement on his extensive estates. He has built a good slated dwellinghouse and out-houses on the greater number of his farms, and encouraged an improved system of cultivation among his tenants. Having engaged an agriculturist to reside on his estate, and go among his tenants to instruct them, every one of them has now portions of wellmanaged green-crops. Some turnip-crops which I saw to-day would do no discredit to the best farm in East Lothian, either for the quality of the crop or the clean state of the cultivation. I walked over a number of these farms, and feel satisfied that, in thus encouraging the native farmers, Mr Herbert is pursuing a wise course. But he does not begin by merely telling them how to grow green-crops. He first erects housing for the stock in which to consume the green crops profitably; then he provides his agriculturist with mixed grass-seeds, to dis- 
tribute among such of the tenants, free of charge, as have land prepared for them : the only condition being that an equal extent of land must be laid down with good seeds every succeeding year, or, failing that, the first cost of the seeds must be repaid. Then, at present, he pays the whole of the poor-rates, and for some time has also given reductions of rent, averaging twenty-five per cent. His tenants are all dairy farmers, which is probably the safest system that can be followed in their circumstances. They are comfortable, pay their rents with regularity, and there is not on this estate any unoccupied land-a statement which cannot, perhaps, be made of any other considerable estate in the county. Taken as a whole, there seems to be as much prudent foresight exhibited in the management of this property, and as favourable results to both landlord and tenant, as any which I have yet seen in the west of Ireland; and I attribute this chiefly to the fact that Mr Herbert has, for many years, made it his study to understand and see to the discharge of his duties as a landlord.

Approaching Killarney, the country becomes well wooded and rich. The streets were crowded with country people. Proceeding through the town, we drove on about two miles along a finely wooded road, till we reached Muckross, after passing the houses of several resident proprietors.

In the afternoon I rode out with $\mathrm{Mr}$ Herbert, through his grounds and round Muckross Lake, about eight miles. There is not probably in the kingdom a more beautiful ride, through woods of native oak and evergreens, among which the arbutus is a pecu- 
liar feature. That tree grows here naturally in great profusion and luxuriance, and this is said to be the only place north of the Alps where it is found indigenous. The yew and the holly, with the arbutus, make a perpetual verdure in this drive. It runs along a peninsula, dividing Muckross from the Lower Lake of Killarney ; and every now and then skirting their banks, it affords views of the majestic mountains which overhang them. From the bridge over the stream which connects the two lakes, the prospect is most beautiful. The fine mountain Glena on the right, rising abruptly from the lake, with oak and evergreens fringing its base, and the feathery larch and fir stretching far up its rugged sides; and on the left the brown Torc, wooded from the lake nearly to its summit; while immediately beneath, the waters of both lakes are rippling on their shores-all form a scene which one is unwilling to leave. Crossing the bridge, and riding onwards, a neat cottage is seen, where tourists are allowed to enter and eat their repast. Landing-places from both lakes are near it. But I must not pause on the picturesque, for pages might be written without conveying more than a notion of the varied beauty which everywhere greets the eye. Wooded mountains, lakes, and islands, glens and waterfalls, the shooting of the "rapids" through the arch of the ancient bridge, the quiet bays and winding shores, must all be visited to be understood.

Next morning we rowed from Muckross to the western extremity of the lower lake, a distance of eight miles, passing on our left a continuous wood stretching from the lake far up the glens and sides of the moun- 
tain. Herds of red deer frequent this wood, the last place in which they are now to be found wild in Ireland.

We landed at the western extremity of the lake, and walked over a considerable extent of ground, skirting its shores, and running along the river Loune to nearly opposite the castle of Dunloe, which Mr Herbert is desirous of letting in building lots. It is within three or four miles of the town of Killarney, near an excellent road ; the soil is good, dry sharp land, easy of cultivation, and, sloping towards the south, it commands views of the finest description. The Gap of Dunloe, Macgillicuddy's Reeks, with the wooded mountains on the south shore of the lake, the lake itself, and its islands, are all before you. The boating on the lakes, and fishing in the rirer, the banks of which are highly picturesque, add to its attractions. When the railway, now partly constructed, shall be completed to Killarney, this ground will be eagerly sought after, as in few parts of Great Britain could a sweeter spot or a milder climate be found.

The country from this point to the sea, an extent of sereral miles, is a good agricultural district; generally dry, sharp land, with a good depth of soil, easily cultivated, and peculiarly suited to green crops. 


\section{H A P T E R I X.}

THE BLACKWATER-ROSNALEE-SUBLETTING-DROMAGII-KING WILLIAMSTOWN-RECLAMATION OF WASTE LANDS-SUCCESS OF THE EXPERIMENT DEPENDENT ON CON-ACRE LABOUR - CON-ACRE LABOUR DESCRIBEDVALLEY OF THE BLACKWATER-MALLOW TO CORK-MR JEFFRYES' FARMS-EXCELLENT MANAGEMENT OF STOCK-RENT OF LAND-“WASTE LAND" BECAUSE DESERTED-TIPPERARY-LORD HAWARDEN'S FARMS -ROAD SESSIONS - MR BIANCONI - HIS ESTATE - LORD STANLEY'S FARMS-GOOLDS CROSS TO DUBLIN-GLASNEVIN.

ON November 5th, after visiting Muckross Abbey, I proceeded by Killarney towards Kanturk, the first few miles passing through a rather interesting country. On reaching the rising ground three or four miles from Killarney, one is struck with the neatness of the farm houses, stackyards, gates, and turnip fields, all reminding you of the tidiness of small English farms. The hand of improvement has been here, teaching industry and skill, and reaping through these the reward of a comfortable and prosperous tenantry. This is again the estate of $\mathrm{Mr}$ Herbert, and no one can pass it by without inwardly thanking the man who has dealt so wisely and so well with those committed to his charge.

After passing this estate, the road leads through a high cold country, till, crossing the Blackwater, we enter the county of Cork. Along the banks of this river the land 
is of better quality, and continues so for some miles farther. It is wet and undrained, but would pay well for drainage in the improved quality of the grass for pasture, though not suitable for extensive tillage. It is stocked by the small farmers with dairy cows.

Approaching Rosnalee, the property of Mr Leader, you enter a coal district, where an anthracite coal is worked, which is used principally for burning lime. The fields are laid out in large divisions, neatly fenced with thorn hedges, and interspersed with plantations. Here the farming is under the management of Scotch stewards. The turnip crops are excellent. Mr Leader keeps a large dairy, comprising 70 Ayrshire cows. The milk is made into butter for the London market.

The management of this farm appeared careful and judicious. There are excellent green crops and ample house accommodation; but, being situated in the pauperised union of Kanturk, the whole profits are consumed by the claims of poverty. Last year the net returns of the farm for rent were $24 \mathrm{~s}$. $6 \mathrm{~d}$. an acre ; the rates and taxes on it 25 s. an acre!

Walking through the fields I came to the estate of a neighbouring non-resident proprietor, who had let his lands to a middleman, and he again had parcelled them out to cottiers. The whole land was swarming with miserable huts, in some of which as many as three families were congregated. They had no crops or stock of any kind; the land was waste, and the people must perforce live by plundering their richer neighbours. Now, this estate and its paupers must be supported by the industry of the well- 
conducted farmers of the union, which is a monstrous hardship. So wretched are many of these people, that a poor boy, whom we saw gleaning in a potato field, had secured from his forenoon's toil only about two handfuls of half-rotten potatoes. He was starving, and came running like a hungry dog; and I fear no care in the workhouse now can bring that poor neglected creature through. He said he would go to it next day, but the repugnance to the workhouse is universal. Anything will be endured, short of absolute and continued want, rather than enter its imposing gates.

Proceeding on to the Blackwater river, I walked with $\mathrm{Mr}$ Leader along a tract of excellent holm land on its banks, passing some first-rate green crops, turnips and mangold, on one of $\mathrm{Mr}$ Nicholas Leader's farms. We soon reached an extensive flour-mill, where the grain of the surrounding district is bought and manufactured.

Next morning I accompanied Mr Nicholas Leader to his farms at Dromagh, one of the ancient castles of the O'Keefes, now converted into a comfortable farmyard. $\mathrm{Mr}$ Leader keeps a dairy stock, rearing and feeding off their produce. His stock and green crops were well managed. As to the cheapness of labour in this country, I saw here a proof that low wages and cheap labour are not synonymous terms. Two men, at $8 \mathrm{~d}$. a-day each, were employed to feed 32 cattle, cutting their turnips and cleaning the feeding-houses, \&c. In Scotland one man would do the whole with ease. Hay, by taskwork, costs 3s. $6 \mathrm{~d}$. an Irish acre for mowing. It could 
be done for the same in Scotland. Ploughmen do nearly as much work in the field as a Scotch ploughman, but here they require help in cleaning out the stables. Theft is so common that green crops must be watched night and day; and, for the same reason, it is not safe to keep a sheep stock in this part of the country.

Mr Leader kindly drove me to King Williamstown, where an experiment was made by Government on a portion of the crown lands, to ascertain whether waste mountain land, at a high elevation, can be profitably cultivated. After driving some twelve miles through a cold bleak country, we reached this estate, which is very extensive. It is situated near the source of the Blackwater in the county of Cork, and bordering with Kerry. It is 850 feet above the level of the sea, generally deep bog, but part of it black land resting on clay, and part dry sharp land. It is by no means the worst quality of mountain bog; and, though at a high elevation, it is reached by a gradual ascent along an excellent road; and the land is an easy slope, with a northerly aspect, on the spot where the model farm has been placed. The improvements were begun in 1833, under the superintendence of the Board of Works, and the immediate management of $\mathrm{Mr}$ Boyan. The first thing was to open up the country, by constructing an excellent road communicating with Kanturk and Tralee, the estate being about fourteen Irish miles from the former. It was then partitioned out into small farms with suitable steadings, in each of which the individuals who formerly held the lands were placed. A village was built, with 
an inn, a school, carpenter's, blacksmith's, and other tradesmen's houses. The model farm of 300 acres was then laid out, and farm-buildings erected.* The land was divided into fields which were drained-though, from the rushy appearance of the fields, that operation seems to have been very imperfectly done. A limestone quarry being fortunately discovered at no great distance, a kiln was erected, and this valuable manure for reclaiming mountain land got at a very moderate expense on the spot. In this, the experiment had a peculiar and a very great advantage. A stock of dairy cattle was gradually introduced, green crops cultivated, and a regular rotation established.

The land was worked by con-acre labour. That is, the people assembled in spring, and agreed to pay $£ 6$ an acre for the use of wild heath land, to grow potatoes. They got lime for it, but put in the seed and tilled the land at their own cost, giving their labour on the farm till it paid this exorbitant rent. A second crop of potatoes was taken, dung being applied to the land, and the rent proportionally increased. The land was then ready for turnips or oats, after which it was sown out with grass seeds, and laid to pasture. The moor was thus converted into grass at no other expense than that of seed, inasmuch as the labour of the people in cultivating their own potato crops reclaimed it from its natural state, and the rent they paid for the use of the ground repaid their labour in the subsequent pro-

* The Government pay rates and county-cess for all their tenants here. Some of those who are most favourably situated are said to be going on well, but many of them will be obliged to give up their holdings on account of the failure of the potato. 
cesses of improvement. As long as the potato remained sound, the experiment prospered; but now that money wages must be paid, it does not succeed.

The success of the system was thus totally based on the potato; and the scheme seems rather to have been intended to show how many people could be kept alive by the cultivation of waste lands, than to exhibit an example of an improvement in the condition of the people resulting from the reclamation of land. Better far that this tract should be left to the undisturbed possession of the curlew and the solitary raven, than that it should be made the means of perpetuating a system which only thrives through the misery of the people.

The failure of an experiment may be as instructive as its success. At this moment, if the fee-simple of the model farm, with the stock and crop on it, were sold, they would not repay the capital sunk in the undertaking, while it is acknowledged that, without con-acre labour, the returns will not pay the expenses. The experiment at King Williamstown may therefore serve as a beacon to warn others against any similar attempt.

It does not follow, however, that these waste lands are irreclaimable. Lying four hundred miles farther south than the sheep farms of Sutherland and Caithness, whence come the finest Cheviot wethers of the great Inverness sheep fair, they have the advantage of a much milder climate. Surface drains, for the improvement of the land as sheep pasture, might be cheaply executed, and lime, for top-dressing it, obtained on the spot. There are now excellent roads of access, and the whole district lies within twenty miles of the line of 
railway from Cork to Dublin. In this district, and the adjoining tract in the county of Kerry, it is said that there are upwards of 200,000 acres of land, which, I have no doubt, might be converted into valuable farms for grazing sheep or cattle.

We returned from King Williamstown through Newmarket, where a whole street is converted into an auxiliary poor-house. In Kanturk also several houses, tanneries, \&c., are in requisition for the same purpose. Extensive improvements are here going on by Sir Edward Tierney, who is enclosing, draining, and cultivating his estate, and giving a great deal of employment, for which he pays in cash.

I make this remark, as the con-acre system was hitherto the universal plan of conducting the labour of farms in this part of the country. According to the quality of the land, it was charged to the labourer at from $£ 6$ to $£ 8$ and $£ 10$ an acre per annum, the most worthless heath being let, when limed, at the former sum. The rent was paid by the labourer's work; and the system was, to let out as much land as paid the whole labour bill of the farm. In every way the necessities of the labourer were taken advantage of. The highest rent was charged, and that was paid by the lowest rate of wages. This system of course fell to pieces when the potato failed; and the farmer, having no capital to pay his labourers in cash, failed also.

On the 7th of Norember I left Rosnalee for Cork, proceeding down the valley of the Blackwater as far as the railway station at Mallow. I passed through many miles of fine country in this valley, which improves 
towards Mallow, becoming more wooded also, and picturesque. Some of it is under good management, some very bad, and much of it would be greatly improved by drainage. Limestone is abundant. This valley continues to Youghal, where the Blackwater falls into the sea. The soil seemed a fine free alluvial loam.

For some miles we skirted the banks of an unfinished canal, which had been commenced many years ago, but never completed. Coming from Killarney I passed the new line of railway which is formed, and considerably advanced towards completion, for about ten miles from that town. The genius of the country seems to lead the people to jump too rapidly to conclusions, commencing undertakings without sufficiently counting the cost. The canal is superseded by the railway, which will no doubt be completed in a few years; for, independent of the tourist traffic to Killarney, it will open up a rich and extensive tract of country, extending to Tralee. But it appears most inconsiderate to have begun the railway at Killarney, instead of continuing it by degrees from the point of junction with the main line. Beginning at the wrong end, the whole work must of course be isolated till completed ; whereas, if it had been begun from the main line, the distance would have been gradually shortening, and the capital expended would sooner come into play.

From Mallow to Cork by railway the country is a succession of eminences, not of a very promising character, but capable of much improvement by drainage and good farming.

At Cork I was fortunate in meeting with $\mathrm{Mr}$ 
St John Jeffryes of Blarney Castle, to whom I had an introduction. This gentleman farms about 2000 acres of his own estate, which is about three miles to the north-west of the city, and over which he kindly accompanied me. It is divided into several farms, with threshing-mills on each. Turnips are grown very extensively, and white carrots for the farm-horses. There are about 300 acres of irrigated meadows, which afford excellent food for the dairy and other stock. The dairy consists of 170 cows, partly short-horn and crosses, but all of a large size. On one farm the cows are fed constantly in the house, and they do quite as well as those which are pastured, while the same number do not consume nearly as many acres of produce, and make a vast quantity of manure. The whole stock are fed daily on cut hay steeped in distillery wash. This seemed an excellent and very palatable food. The milk-cows get draff mixed with it. They are fed four times daily; in the morning and evening with the hay mixture, twice during the day with turnips. All the turnips are cut with gardeners' cutters. The milk is sold at a fixed price to a man who takes it daily at the farm.

Besides the cows, Mr Jeffryes feeds out part of their produce-viz., 100 calves, 100 year-olds, and 100 twoyear-olds, which are turned out fat annually. The calves are first fed in pens singly; they are then put into loose-boxes, three in each, for the winter. These boxes are constructed on the plan of Mr Blair Warren of Norfolk, with a feeding passage in front of them, and a door to each for removing the dung when 
it accumulates. They are very cheaply and simply made with home wood, thatched, the walls of interlaced wicker-work. The calves are fed on the hay mixture, and as many cut turnips as they can eat. They were in a very thriving state. The year-olds are kept in sheds and open courts, twenty or thirty in each, fed on turnips and straw. The two-year-olds live partly in small courts with sheds, three or four in each, but principally housed in loose-boxes. They get turnips three times a-day, besides the cut hay mixture. They were very thriving cattle.

A sheep-shed has just been completed, in which about 200 sheep will be fed this season on Mr Huxtable's plan. The sheep were clipped before being put in, and yielded 1s. 3d. worth of wool each.

The horses are fed on cut hay, $70 \mathrm{lb}$. each of white carrots, and a few pounds of oats daily.

Mr Jeffryes sows his wheat on clover lea, using furrow pressers, without which he thinks it would be imprudent to sow it at all after grass or clover. The Suffolk drill is used for sowing after fallow or green crops, where the land is loose. For winter beans, which are now coming up, the stubble is dunged, and the seed sown in every third furrow, the surface being harrowed afterwards.

The soil generally is a red gravelly turnip soil, resting on a very stiff and obdurate subsoil. It is being drained 4 feet deep and 21 feet apart. The cutting, which is very hard to do, costs $6 \mathrm{~d}$. per rood of 18 feet.

The land would let here at 20 s. to 30 s. an English acre, rates $4 \mathrm{~s}$. to $7 \mathrm{~s}$. an acre more. Any quantity of 
manure can be got from Cork, where there is also a market for all kinds of produce.

The old castle of Blarney, with its " blarney stone," and famous "groves," stands in the middle of this extensive occupation. The water-meadows are in the valley below the castle. The land surrounding it is old pasture of fine quality, resting on limestone, a mass of which is here most usefully protruded through the surface.

So near Cork, I was surprised to find that $\mathrm{Mr}$ Jeffryes did not set a watch on each of his turnip fields, like everybody else in this country. He takes a different plan, having offered a reward of a guinea to any person who prosecutes to conviction any one who is found thieving his turnips. The first year this plan cost about fifteen guineas, but it gradually fell off, and now he has never a complaint of loss.

Mr Jeffryes has spent many years of his life in bringing these farms into their present high state of cultivation, and especially in perfecting the arrangements of his dairy and feeding stock. He might be disposed to subdivide, and let them in suitable-sized occupations, to skilful and enterprising tenants.

In cleaning grain for the market, in this country, it is not considered necessary to prepare it so carefully as we do in Scotland. Light grain and seeds of weeds, which would be blown or sifted out with us, are here not found injurious to its sale. This may in some degree account for the apparently low price of Irish grain, when it comes to the English market.

It is difficult for a stranger, going through the 
country, to form a correct judgment as to whom he should blame for the wretched cottages and villages he passes. On many estates these are built on land which is held from the head landlord on long leases, and sublet by his tenant. In such cases the landlord may have no more control in the matter than the traveller, who hastily concludes that, because So-and-so owns the land, therefore he must be a heartless fellow to permit such a state of misery to continue.

Leaving Cork on the morning of 8th November, I returned by railway to Mallow. Thence to Butterant, the country along the line is much in need of drainage. After passing Buttevant northwards, the land improves on to the county of Limerick, where the railway soon after enters the "golden vein." And here "waste" land is seen-that is, land deserted by the tenant, and unoccupied by the landlord. The law of ejectment is somehow defective in permitting a tenant to leave his land, and yet not giving the landlord power to enter to it. If the tenant quits the farm himself, taking with him stock and crop, and performing no act of tillage, but only keeps a person in the house, the landlord, before he can serve notice of ejectment, must allow one year's arrear of rent to accrue. The ejectment cannot be enforced for six months more, and the tenant may redeem his farm any time during another six months. In this way, the land may be, and often is, waste for two successive years, rates and taxes accumulating all the while.*

* We have a law in Scotland, which might be very usefully introduced into Ireland-that, where a tenant deserts his farm and leaves it unlaboured, at the usual time of labouring, the landlord may obtain an imme- 
From Charleville to Tipperary, and thence to Dundrum, the land is all good, though generally in need of drainage. At Dundrum House I saw Lord Hawarden, who kindly took me over his grounds, and also showed me his sheep and cattle. The variety of wood and evergreens in the pleasure-grounds is very pleasing; and the rich pasture-lands, extending as far as the eye can reach, interspersed everywhere with fine old trees, and fat beeves and flocks of sheep grazing beneath them, form quite an English landscape. The rapidity of the growth of trees here is surprising. Lord Hawarden pointed out to me three large oak-trees planted by him no longer ago than 1813. Hollies and laurels grow to the size of forest trees; and these again shoot up to a great height with clear bright stems, showing the richness of the soil and genial climate. There is a great extent of plantations on this estate, which is very unusual in any part of Ireland farther west.

Lord Hawarden has about 3000 acres of land in his own occupation, a great proportion of which is in grass. The stock consists of two or three hundred head of cattle, and 1400 sheep. The sheep are bred on the land, and are of prime quality. The cattle are mostly half-bred Durhams, bought in the country as calves, and kept till turned out fat. 200 acres of hay are made annually.

I accompanied his lordship to a road session, where the gentry were met to pass the accounts for making

diate order on the tenant to find security for the rent; and on his failure to do so, may procure authority at once to resume possession by an exceedingly simple process. 
and repairing roads for the half-year. The contracts had all been taken by small farmers, (a mile or two by each,) of whom a great number were present.

In the afternoon Mr Stewart, Lord Hawarden's agent, accompanied me in a drive through the adjoining country. There will be many fine estates in this quarter for sale; and, as the people are now surrendering their farms, it is thought that a stranger would incur no danger by purchasing or leasing land here. Yet there are disagreeable legends associated with bushes here and there on the road-sides, whence issued the deadly shot, too recent to make one feel altogether comfortable. Iron shutters, pistols on the mantel-piece ready capped and loaded, hall doors heavily barred and bolted, indicate a present of insecurity. A well-appointed railway, with handsome road-side stations, setting down and taking up punctual busy people six times a-day, running through the centre of the county, with roads diverging from every station, and coaches and cars constantly traversing them, point to an early future of prosperity and peace for Tipperary. It is not the lowest class, or the most destitute, who commit the murders which have shocked society and made the name of this county infamous: the small farmers, who themselves traffic in subletting to those below them at exorbitant rents, grinding the faces of the very poorest, are said to be the perpetrators or chief instigators to crime.

On the morning of 9 th November, I breakfasted with Mr Bianconi, at his mansion on the Suir, within a mile of Goold's Cross station on the Dublin and Cork railway. This well-known and remarkable man is an Italian by 
birth-a proof, as he himself says, that a stranger may succeed in Ireland. He commenced his career, between thirty and forty years ago, in Clonmel, "making," as he told me, "a shilling a-day, and living upon eightpence." After saving a little money, he started a car in 1815 from Clonmel to Cahir. With the profits of this he extended it to Tipperary and Limerick, and then to Cashel and Thurles, and subsequently to Carrick and Waterford. He paid everybody in his employment fair and liberal wages, and insisted on punctuality, sobriety, and honesty in return. Gradually he extended his line of communication further over the country, and by his enterprise contributed much to open up and civilise it. As the railways drive him off the main lines of traffic, he extends into remoter districts, and every part of the west of Ireland is now daily traversed by his conveyances. While accommodating the public, he has also realised a fortune for himself, and purchased a fine estate on the Suir, a few miles from Cashel.

The house is well situated, commanding a view over a rich country, with the river Suir about 100 yards from the front door. The grounds are ornamented with statues and vases in the Italian style, and the rooms adorned with paintings by the old masters. I accompanied Mr Bianconi over his estate, where he appears to continue the same liberal system which insured his success with the public. His land is very moderately rented, and he is building commodious and comfortable slated farm-houses and out-buildings for his tenants. The plan, which is the same in all, for heating the dairy 
is worth noting. The dairy is immediately behind the kitchen, and, by an economical and ingenious contrivance, the flue of the kitchen fire is carried all round the dairy, thus heating it cheaply in winter, while another flue, leading directly up the chimney, is used in summer. The farm-buildings will cost from $£ 4$ to $£ 5$ an acre over $\mathrm{Mr}$ Bianconi's estate.

Near Cashel, Lord Stanley's agent will be glad to let one or two farms of 300 to 400 Irish acres each : said to be very good land on limestone, principally in grass. He will build suitable farm-houses and out-buildings. The rent expected is upwards of $£ 2$ an Irish acre, the tenant paying county rates and half of poor-rates.

Joining the railway at Goold's Cross, I proceeded direct to Dublin, passing through Queen's County and Kildare. Farmers might examine the land on the line of this railway all the way to Limerick. Plenty of the best land, it is said, will be let on moderate terms.

At Dublin, after having been honoured with an audience by the Lord Lieutenant, I, at his Excellency's request, visited the model agricultural school and farm of Glasnevin, where I met Dr Kirkpatrick, Inspector of Agricultural Schools in Ireland, and Mr Donaghy, the teacher and manager of this farm. I accompanied them over the farm, which now extends to 128 English acres, a very large addition having been recently made to it, involving a change of plan, and the erection of a new range of farm-buildings. Scope has now been got. for exhibiting in operation a 3,4 , and 5 course rotation of crops, so that the pupils may learn the details of each 
system, and be able to apply whicherer is thought most suitable in the locality to which they are afterwards transferred. We then went to the school-room, where we found about forty young men, agricultural pupils. Mr Donaghy examined them on the theory and practice of agriculture, in which they appeared to have acquired great proficiency.

This concluded my agricultural observations in Ireland, as I left Dublin next day for Kingston and Holyhead. The mail packet, notwithstanding a heavy gale, landed us in about five hours at Holyhead. Seventy years ago, Arthur Young, returning from a tour in Ireland, thus describes his perilous voyage. On the 17 th October, he got on board the packet, but was landed next morning, as the wind was foul :-_" On 19th October, the wind being fair, I went back to the ship; met with a fresh scene of provoking delays, so that it was the next morning, October 20th, before we sailed. * * * We were, by contrary winds, blown opposite to Arklow sands; a violent gale arose, which presently blew a storm that lasted thirty-six hours, in which, under a reefed mainsail, the ship drifted up and down, wearing in order to keep clear of the coasts. The wind blew in furious gusts; the waves ran very high; the cabin windows burst open, and the sea pouring in set everything afloat; and among the rest, a poor lady who had spread her bed on the floor. We had, however, the satisfaction to find, by trying the pumps every watch, that the ship made little water. It pleased God 
to preserve us ; but we did not cast anchor in Milford haven till Tuesday morning, the $22 \mathrm{~d}$, at one o'clock." Five days were thus occupied on a royage which is now regularly made in as many hours. Would that an improvement equally great could be discerned in the comfort and condition of the people of Ireland! 


\section{CHAPTER X.}

REFLECTIONS - FARMERS' INVESTMENTS - LANDLORDS' INVESTMENTS OBSTACLE TO THE LATTER-INDEFINITE NATURE OF RATES-COMPARATIVE STATE OF THE COUNTRY IN 1779 AND 1849-ARTHUR YOUNG'S TOUR-RISE OF RENTS-REDUNDANCY OF POPULATION-PROPORTION IN EAST COMPARED WITH WEST-DEPENDENCE ON POTATO-RELIEF-WORKS UNA VOIDABLY UNPRODUCTIVE-INCREASE OF GRAND-JURY CESSAND POOR AND LABOUR RATES-ALL PRIMARILY THROWN ON THE TENANT-ABANDONMENT OF FARMS-NECESSITY OF A LIMITATION OF RATES TO ENCOURAGE IMMIGRATION OF CAPITALISTS-EMIGRATION-VARIABLE AMOUNT OF VALUATION-PROPRIETY OF DISCOURAGING CON-ACRE-SIMPLIFICATION OF SALE AND TRANSFER OF LAND-INCIDENCE OF GRAND-JURY CESS UNJUST TO TENANT-ADVANTAGES OF TRANSFERRING IT TO LANDLORD-CURE FOR ABSENTEEISM-UNEXHAUSTED IMPROVEMENTS-POPULATION OF CONNAUGHT-COMPARED WITH ENGLAND AND SCOTLANDNECESSITY FOR A COMPREHENSIVE MEASURE.

IN briefly recording the general impression left on my mind by my visit to the west of Ireland, altogether apart from the social state of that country, which will be afterwards considered, I may state that I was much surprised to find so great an extent of fine fertile land. The interior of the country is very level, and its general character stony and dry; the soil deep and friable. The humidity of the climate causes a very constant vegetation, which has both advantages and disadvantages. It is favourable for grass and green crops, but renders it necessary to employ very vigorous and per- 
serering efforts to extirpate weeds. The abundance of lime everywhere, both in the rock itself, and as sand and gravel beneath the surface, are of the greatest value. The roads, in all directions, are good, and the railway to Galway when opened, and that to Limerick and Cork already opened, offer great facility for the disposal of produce. The best breeds of cattle and sheep have been introduced with the greatest advantage.

A farmer taking land in any of the western counties with a view to its cultivation, will be welcomed as a benefactor by the labouring population. He will of course wisely avoid any interference with the parties still in possession of land, as there is plenty of land in the country unoccupied; and numerous demesnes which have always, hitherto, been in the proprietor's hands, but which many are now desirous to let. These are generally provided with good buildings ; but, at any rate, there are several landlords willing to erect, at their own expense, all necessary buildings, as mentioned in the foregoing pages. On making their agreements, they must take care that the party with whom they wish to agree has full authority to conclude a bargain ; and I would again caution them not to enter into any engagement without fixing precisely the amount of rates of all kinds, as well as rent, for which they are to be liable. If prudent, skilful men, with sufficient capital, go to that country, they can scarcely fail to succeed. Rents are now considerably lower than land of similar quality can yet be got for in this country. Indeed, I think the outlet which farmers from England and Scotland are likely to find in the best parts of the West of Ireland, 
may prove a wholesome check to the gradual, but constant, rise of rents, which has been going on for many years back on all the green-crop lands of the northern division of Great Britain. There is one point of practical detail in which new men would probably introduce a change. I mean as regards the earlier maturity of sheep. On the great proportion of good land in the West of Ireland there can be nothing to prevent sheep being sold fat at 12 to 15 months, instead of three years as at present, turnips or other artificial winter food being of course provided. The accomplishment of this change would make a very material increase to the wealth of that country.

The immense number of estates which will now be brought to sale under the Encumbered Estates Act, renders it necessary for me to offer one or two remarks on the probability of purchasers being found to offer for them. Irish proprietors, or their encumbrancers, must not delude themselves with the idea that a capitalist will fail to consider the difference betwixt a dilapidated estate, without buildings, fences, or any other of those improvements which the care and outlay of years have accumulated on an English property. They will make all due allowances for the difference of having everything to send to a distant market, instead of finding a market at home. The state of the cottages on estates will be considered, as no humane man would wish to see the present miserable hovels continued, in the event of his becoming a purchaser. He will therefore calculate on an annual deduction from his rental for improving them. Then, without a very adequate 
inducement, a man will not leave this country, with all its conveniences and luxuries, the society he has been accustomed to, the well-ordered people among whom he has hitherto dwelt, - to exchange these for a residence in the West of Ireland, where, for some years to come, there must of necessity be much misery to be witnessed and encountered. He will look to the causes which produced an unsound, and, in many cases, too high rental, and to the possibility that the burden of grandjury cess may be laid hereafter on the right shouldersthose of the landlord instead of the tenant. And when all these things are taken into account, a purchaser still has before him one thing which, if not settled by the interposition of Government, will render the Encumbered Estates Bill a dead letter, in so far as regards the distressed districts of the West of Ireland, and that isTHE INDEFINITE INCREASE OF RATES.

Until a limit shall be placed, beyond which individual property cannot be made responsible for the whole poverty of a union, there can be no improvement, and no hope of new men, with capital, venturing it in a speculation, the result of which is placed altogether beyond their control. The consideration of this leads me into a large question, which I will merely attempt to touch upon.

In passing through the western counties of Ireland, it may not strike the stranger that there is any apparent redundancy of population. The numerous habitations are generally in bye-roads, huddled together; or on the margins of bogs ; or walled in on the summit of a barren rock, (as I saw one case in the county of Limerick,) 
and therefore unnoticed by the traveller; or on very rocky, stony ground, where the plough cannot be economically used, and where, from the frequent rocky obstructions, one does not see at once the dense population which is sheltered by many an Arabia Petræa in the West of Ireland. Numbers of the people also are lodged in the union poor-houses. It is only, therefore, by consulting the statistical returns that accurate information on this point can be obtained.

Before proceeding to do so, however, it will be instructive to compare the state of the country at the time of Arthur Young's visit, with what it is now. In 1779 , just seventy years ago, that celebrated agricultural writer made a tour through Ireland, an account of which he soon after published. It is full of agricultural information as to the state of the people, the landlords, and the land. It gives very full details as to rental, products, tenantry, labouring poor, price of provisions, roads, waste-lands' improvement, public works, flax culture, free trade! Indeed, nearly all the questions which now occupy the public mind in reference to Ireland are there treated of ; and much that Arthnr Young says is as applicable to the present condition of Ireland as it was then. "I have reason to believe," he says, "that five pounds sterling per English acre expended over all Ireland, which amounts to $£ 88,341,136$, would not more than build, fence, plant, drain, and improve that country, to be upon a par in those respects with England. And farther, that if those 88 millions were so expended, it would take much above 20 millions more -or above 20 s. an acre-in the hands of the farmers 
in stock of husbandry, to put them on an equal footing with those of her sister kingdom; nor is this calculation so vague as it might at first sight appear, since the expenses of improvement and stock are very easily estimated in both countries. This is the resolution of that surprising inferiority in the rent of Ireland: the English farmer pays a rent for his land in the state he finds it, which includes not only the natural fertility of the soil, but the immense expenditure which national wealth has in the progress of time poured into it; but the Irishman finds nothing he can afford to pay a rent for, but what the bounty of God has given, unaided by either wealth or industry."-Part II. p. 12.

Can it be said, in the immense majority of cases, that there has been any change in this, or that the landlords generally have expended any capital in providing necessary buildings, \&c., on their farms. In that respect there has been no change; but as regards rent, the advance has been enormous, arising partly, no doubt, from the general accumulation of wealth throughout the kingdom, but principally from the competition for land caused by the rapid increase in the population, and the encouragement of the con-acre potato system. The following table shows a comparative view of

Prices and Rates of 1799 and 1849, in the County of Limerick.

$$
\text { Oct. } 1779 . \quad \text { Oct. } 1849 .
$$

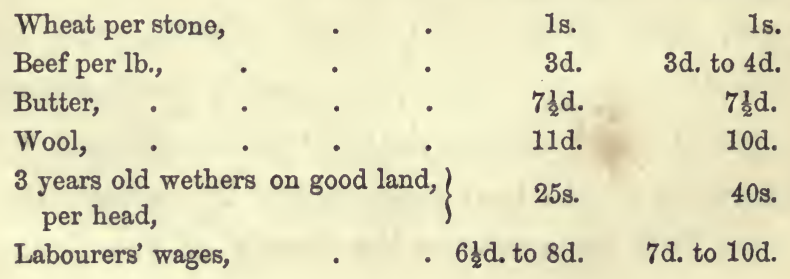




\section{Oct. $1779 . \quad$ Oct. 1849.}

Rent of feeding land per Irish acre, $\quad 30 \mathrm{~s} . \quad 45 \mathrm{~s}$.

Rent of "corcase" (rich alluvial) land, 30s. 70 s.

Price of a ton of hay, - . $35 \mathrm{~s} .20 \mathrm{~s}$. Con-acre rent of potato ground per
Irish acre,

Grand-jury cess per acre, - 3d. to 6d. 2s. 6 d. to 5 s.

Poor-rates per $£$ - . nothing. 3s. 7d. to 11s. 2 d.

In the foregoing table there is much to explain the bad feeling which exists between landlord and tenant. But it must not be overlooked that the present scale of prices is lower than has been known for some years, and probably below the future range, on account of the quantity of stock and crop thrown on the market through the general alarm of falling prices, and the fears of, and necessity to provide for, the payment of heavy rates.

It will be noticed that the price of butcher-meat does not stand much higher than in 1799 ; but the size and quality of the animals have greatly improved, as may be seen by the relative prices of three-year old wethers, which have thereby increased in value 60 to 70 per cent.

Some progress in the same direction, though not in an equal degree, is shown by a comparison of the average produce of grain crops for the whole of Ireland, as estimated by Arthur Young, with that of the constabulary returns for 1848 .

PRODUCE OF GRAIN CROPS PER ENGLISH ACRE.

1779.

\begin{tabular}{|c|c|c|c|}
\hline Wheat, in bushels, & - & 18 & 21 \\
\hline Oats, $\quad \ldots$ & - & 28 & 35 \\
\hline Barley, ... & - & 28 & 35 \\
\hline Potatoes in barrels, & tones, & 52 & 30 (bad crop.) \\
\hline
\end{tabular}

* Rent previous to potato failure. 
To complete the picture, it will be necessary to examine the condition of the labourer in 1779 and 1849.

"A cottar," says Young, "with a middling family, will have two cows: there is not one without a cow. All of them keep as many pigs as they can rear, and some poultry. Their circumstances are rather better than twenty years ago. Their acre of garden feeds them the year through: nine months on potatoes, and the other three on oaten bread from their own oats. The consumption of potatoes not increased in twenty years. A family of five persons will eat and waste forty-two stone of potatoes in a week. They are not addicted in any remarkable degree to thieving." (Part I.) "I have been in a multitude of cabins that had much useful furniture, and some even superfluous; chairs, tables, boxes, chests of drawers, earthenware, and, in short, most of the articles found in a middling English cottage; but, upon inquiry, I very generally found that these acquisitions were all made within the last ten years, a sure sign of a rising national prosperity." (Part II. page 36.) In the county of Kerry, however, the state of the poor is represented-as "exceedingly miserable, owing to the conduct of men of property, who are apt to lay the blame on what they call land-pirates, or men who offer the highest rent, and who, in order to pay this rent, must and do relet all the cabin-lands at an extravagant rise, which is assigning over all the cabins to be devoured by one farmer. The cottars on a farm cannot go from one to another in order to find a good master, as in England ; for all the country is in 
the same system and no redress to be found. Such being the case, the farmers are enabled to charge the price of labour as low as they please, and rate the land as high as they like. Owing to this, the poor are depressed: they live upon potatoes and sour milk, and the poorest of them only salt and water to them, with now and then a herring. Their milk is bought; for very few keep cows ; scarce any pigs; but a few poultry. Their circumstances are incomparably worse than they were twenty years ago ; for then they had all cows." (Part I. 125.)

Seventy years have passed away, and the cottars of Kerry are in a worse condition now than they appear to have been even then. Those of Limerick, Clare, and Tipperary, as described in the two first extracts, are forgotten; their descendants, instead of showing any continuance of that "rising national prosperity" mentioned by Young, have fallen into a state of the utmost wretchedness. Their mud hovels are worse ; their wages nominally a little more: but as wages are usually paid by con-acre, and as con-acre rent has increased in a still greater degree, the condition of the cottar is really much worse than in 1779. This is, of course, without considering the failure of the potatoes; for that has completed their ruin.

The following figures place the matter clearly before us :-

1779.

5 d. to $8 \mathrm{~d}$.

Labourer's wages,

Con-acre rent of potato groufnd per acre, $65 \mathrm{~s}$. to $120 \mathrm{~s}$.
1849.

6 d. to 10 d.

120 s. to 200 s.

The rise in wages has been from a fifth to a sixth, that of con-acre rent about a half to a third. The 
cottars' "one or two cows" have disappeared, and very few now have even a pig.

It would seem, therefore, that the increased rent now paid by the farmer, must have been made partly from the increased produce already shown, and partly from the higher rent exacted for the labourer's conacre, or (what is the same thing) for the less proportion assigned to the labourer as his share of the produce. It certainly cannot be said to have arisen in any degree from the outlay of capital on the part of the landlord in executing permanent improvements, and thereby increasing the productiveness of his land.

That it has risen enormously there can be no doubt whatever.

$\begin{array}{ccc} & 1779 . & 1849 . \\ \text { The rent of feeding land in the county of Limerick was } & 30 \mathrm{~s} . & 45 \mathrm{~s} . \\ " \text { of " corcase" rich alluvial meadow-land, } & 30 \mathrm{~s} . & 70 \mathrm{~s} .\end{array}$

And this must in great part be ascribed to the ruinous competition for land consequent on an increase in the population far more rapid than is warranted by the increased development of the resources of the country. It could not have occurred, therefore, except by the increasing numbers gradually deteriorating in their condition, and at length becoming wholly dependent upon one kind of food, which failed them at last.

Here it will be right for a little to consider the question of a redundant population. The following figures show the proportions of people to the number of acres under grain, in four of the best circumstanced agricultural unions, and in four of the worst, in Ireland for 1848 :- 


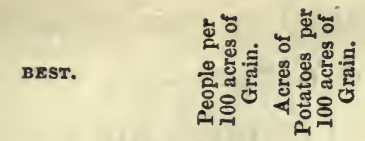

Dunshaughlin (Meath) 100 Enniscorthy (Wexford) 103 Ardee (Louth \& Meath) 129 Downpatrick (Down) 124

$$
\overline{456} \quad \overline{57}
$$

worst.

West Port (Mayo)

Bantry (Cork)

Clifden (Galway)

Kenmare (Kerry)

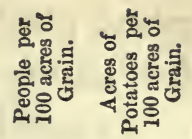

$1039 \quad 62$

$1221 \quad 120$

$1593 \quad 84$

$1530 \quad 175$

$\overline{5383} \overline{441}$

Average, $\quad 114 \quad 14 \frac{1}{4}$

Average, $\quad 1345 \frac{3}{4} \quad 110 \frac{1}{4}$

The first four unions thus show an average of 114 people for every hundred acres of grain; the last four of 1345 people for the same quantity. The second column shows the natural consequence of this difference of population. Fourteen acres of potatoes for every hundred of grain sufficed for the necessities of the population in the four best unions, while the prodigious numbers in the four worst compelled a resort to an inferior but more productive food, and produced a proportion of 110 acres of potatoes to every 100 acres of grain. There was thus nearly a total dependence on the potato ; for, if we take the four first unions as approximating to a right proportion between population and grain produce, we shall find that twelve out of every thirteen people in the worst unions were wholly dependent on the cultivation of that root.

The social system of the West of Ireland may truly be said, therefore, to have been based on the potato. The con-acre labour enabled men without capital to compete with each other for land; hence the rents steadily increased; and the evil was perpetually extending, from the effects of this food producing a contented indolence in the habits of the people, 
whose potato cultivation required no continuous labour, but, on the contrary, induced a "precocity consequent on an inferior amount of vital energy," now considered by economists the condition most favourable to the rapid increase of the population.

When the potato failed, the whole system tumbled to pieces. The people, no longer able to trust to their potato garden, ceased to con-acre ; the tenant, deprived of con-acre labour, had no money to pay wages in cash, and his land became unproductive; the landlord found his rent disappearing, while a new order of things was at the same time growing out of the confusion.

To prevent the fearful consequences of famine, immense sums were advanced by Government for the employment of the people in "relief works." These were administered by the grand juries, on the understanding that the money so adranced was to be expended in reproductive works, and to be repaid by instalments in a limited number of years. The pressure was so great, however, that it was generally found impossible to control the expenditure in such a manner as to make it reproductive ; and, accordingly, vast sums were squandered on works, some of which, if completed, might be beneficial, but very many can never, under any circumstances, be of the least value to the community. In consideration of the exigency, parliament forgave half the debt, but now insists on the repayment, by instalments, of the other half.

The famine brought disease and crime in its train. Infirmaries, fever hospitals, dispensaries, and prisons, were filled to orerflowing. The expenses of these 
establishments were enormous, and have increased the grand-jury cess in many instances nearly 100 per cent.

The poor-rate, of course, progressed in a far more frightful ratio, increasing in one of the unions of the county of Limerick from $4 \frac{1}{2} d$. per pound in 1846, the first year of the famine, to $11 \mathrm{~s} .2 \mathrm{~d}$. in 1849. For the whole county of Limerick, it is shown, by a report on the financial condition of that county, which was unanimously agreed to by the magistrates and grand jurors, on 24th November last, that the annual expenditure of grand-jury rate, poor-rate, and labour-rate, had increased from

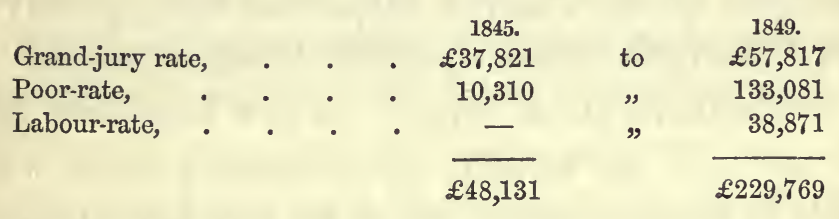

When it is considered that two-thirds of this enormous increase was laid exclusively on the tenant, the reader will be at no loss to understand what he sees in the newspapers about "the flight of tenants," and " abandonment of farms." When the tenant goes, the landlord gets the land to himself, with all its engagements. No rent is coming in; the rate-collectors call regularly for their rates; the bankers are applied to for advances, which they are very chary of making on such doubtful security; and, by degrees, if a definite limit is not put to the increase of poor-rates, the landlords must follow the tenants.

The abandonment of farms, and consequent diminu- 
tion of cultivation, is constantly aggravating the distress by throwing people out of employment, thereby increasing the rates, and at the same time decreasing the annual produce of the land, whence alone the rates can be paid.

The easiest remedy for this disastrous state of things would be the revival of the potato, and its renewed cultivation. To this many landlords cling with desperate hope. Things will mend, they say, if we can only "get over" a year or two. With the revival of the potato, con-acre labour will return, farms will be cultivated, rates reduced, rents paid, and the whole machine be again set in motion.

The lesson which the whole empire has got, however, has been of too sharp a nature for them silently to acquiesce in a return-even if it were possible-to such a rotten state of things. A new foundation must be laid now for building up hereafter a nation which shall be strong in the vigour of its own self-supporting power, the right arm of England, instead of its bane and its disgrace.

The only remedy therefore that can be listened to, is a total change in the agricultural management of the country. That can best be effected by the application of capital to the land, capital on the part of both landlord and tenant. The want of it at present among the landlords is sufficiently shown by the immense number of estates which are already before the new Encumbered Estates Commission, and the generally dilapidated state of the farms in the western counties; while the impossibility of giving any effectual aid to a pauper tenantry by expending capital in draining and 
improving their land, is well illustrated by the following extract from the report of $\mathrm{Mr}$ J. M. Hussey, inspector of drainage for the middle district of the county of Cork.

"The advantages derived from the loans made under the Land Improvement Act, appear to be greatly dependent on the class of persons who obtained them.

"When a proprietor obtained a loan for the improvement of land, either in his own occupation, or in the hands of intelligent tenants, the advantages were considerable ; and lands which, previously to draining, were unsuited to the cultivation of green crops, immediately produced crops not exceeded by those raised on naturally rich dry land, and hence a stimulus was given to the occupiers to commence liming, deep ploughing, and otherwise fertilising the soil ; and they now begin to feel that, by increased skill and energy in farming, it may be possible to meet the present depression in the prices of agricultural produce.

"But turning to those cases where loans were taken on large estates for the purpose of employing the labourers, and thereby lessening the taxation, the results were not such as would warrant a larger and continued outlay.

"A considerable portion of the land thorough drained in small lots on the farms of a poor and nearly pauper tenantry, who were generally unaware of the adrantages derivable from thorough drainage, did not follow it up; and, in consequence, the ground has been left untilled and waste.

"These remarks apply particularly to the extensive 
estates of the Earl of Bantry, who has expended a considerable sum, under the Land Improvement Act, on the lands occupied by tenants having small holdings, who have been completely ruined by the loss of the potato crop, and who do not understand the cultivation of any crops except potatoes and oats; hence the works have not been followed up.

"From these, as well as similar cases, I am of opinion that, where a proprietor undertakes large works of improvement for a depressed and unskilful tenantry, without sufficient funds to render the lands suitable for a superior class of farmers, the drainage works under the Act will not return the required percentage on the outlay; but, on the contrary, where the works are followed up by skilful farmers, that the return will amount to from ten to twenty per cent; and I am happy to say that the latter is the predominant character of the works that have been undertaken in my district, the comparative failures being the exception, not the rule." -17th Report of the Commission of Public Works, p. 23.

An influx of capital must therefore be encouraged, whether it is to come from England, or, as many believe, from the coffers of wealthy men in Ireland, who are said to be waiting for the security under which alone capital can flourish. That security may be attained by the interposition of parliament to fix a LIMIT то тHE AMOUNT OF POOR-RATES.

The effect of an unlimited rate has been already shown to discourage cultivation and increase pauperism. If carried much farther, it may end in total 
bankruptcy. When that period arrives, the State must interpose to prevent absolute starvation; so that it is but a choice of evils; for there can be little doubt that at some point assistance must be given.

It may be said,-why tax others for the faults of a particular union, so long as there is property of any description in the union? No one will buy that property with its present liabilities: the sooner you come to its relief, the easier will it be to render it effectual aid. Nor are the circumstances of the union of a common kind: its entire food has been mysteriously blighted.

And yet, again, upon what principle is the proprietor of a well-managed estate to be made responsible for the pauperism which has been occasioned by the mismanagement of his neighbours, merely because his property is locally situated within some district which has been arbitrarily assigned to it? Upon no just principle, so far as I know, except one which would include an equal burden on all who are embraced within the limits of the same civil government.

Let a limit be fixed, at whatever point the wisdom of Parliament shall decide. When the rates in any union go beyond that point, let experienced officers be sent down to take the management. Economise the cost of collection by transferring the duty to the officers of Inland Revenue: give them the power of compelling payment of the limited rate, offering inducements to prompt payment by liberal discounts, rather than by exacting penalties for arrears, and let the balance be adranced by the State. 
With this should be united EMIGRation-confining assistance to the unions in which government is obliged to aid the rate-payers. Let it be in the power of some safe authorities to send out to our colonies, as free labourers under proper precautions, such able-bodied persons as apply for relief, if they are otherwise clearly ascertained to be redundant, as compared with the requirements of the land in their union. And, until the necessary arrangements are made, let such labourers be employed by task-work in tilling some portions of the "deserted" land in the unions, the produce of which will contribute to the maintenance of the poor.*

As the state would thus adopt heary liabilities, it might be right to take security against these by some equalisation of taxes between the two countries.

A limit being thus placed on the increase of poorrate, the only other difficulty in the way of a capitalist is the variable amount of the valuation on which his rate is chargeable. The more he improves his property, thereby adding to the resources of the State and the employment of the labourer, and the less his neighbour follows the same course, the more unjust is the hard-

* In the electoral division of Castletown, in the county of Limerick, about a fourth of the land is deserted, and the workhouse and auxiliary houses are filled with able-bodied paupers. Much of the land so deserted is of superior quality, and could be tilled with advantage. It would seem a simple arrangement for the guardians to offer the able-bodied, employment by task-work in digging such land at the ordinary rate, after which, it could be sown with oats, also by task-work; and at the same time be manured with a little guano. The crop would at least pay expenses, and the employment would of course lessen rates. Other portions of the deserted land might be let for grazing, if in grass; the takers being of course relieved by the guardians from paying arrears of rates. It is a lamentable absurdity to see the land kept totally unproductive. If the guardians have not sufficient power for the purpose, it ought to be given to them. 
ship when that neighbour has it in his power to demand a new valuation, by which to increase the improver's proportion of the rate, and diminish his own. The period at which such renewed valuation could be demanded, should probably be extended;- say to twentyone years.

The way being thus opened for the influx of capital, and its secure investment in the land, and the safety of the redundant population being also provided for, measures should be taken to guard against the undue increase of population, and the possible recurrence of a second ealamity. Nothing has contributed so much to the entire dependence on the potato, and the consequent increase of a miserable, half-fed, naked population, as the system of CON-ACRE LABOUR. No truck-system is comparable with this. It encourages a tenant without means to offer an exorbitant rent for land, which he pays by exacting one still more oppressive from his labourer. Its two-fold action is to raise rents, and depress wages, by over-competition. Enormous rents are exacted for the patches of potato ground, which are paid by the very lowest scale of nominal wages. It compels an entire reliance on the potato, inasmuch as the labourer can get potatoes only for his food, no money-wages being ever paid. It encourages the landlord to expect a high rent for his land, without demanding from him in return any outlay for its permanent improvement.*

* "A social condition where each family, or nearly each individual, has his field, which furnishes his immediate nutriment, without any necessity for marketing, without the assistance of the miller or the baker, without occasion to demand assistance from his neighbours - that society is deficient in the elements most necessary to the progress of its civilisation."-M. DE Jonses. Industrial Resources of Ireland, by Sir RoBert Kane. 
It will be for the wisdom of Parliament to determine, whether, by removing its causes, they can prevent the renewal of a system which has been so fatally interwoven with the social condition of the West of Ireland. Confidence in the potato is now completely shaken among the labouring classes, and perhaps a better time may never arrive for encouraging a resort to money-wages.

It is equally important to guard against a recurrence of encumbered estates, and the disabilities of landlords. The country has learned a bitter lesson on this point; and the state of Ireland demands that we should not perpetuate a system which locks up the land for family advantages against the just claims of a creditor, and to the general injury of the community. Much good will be done by the Encumbered Estates Act. But the further simplification of the sale, and the removal of all undue impediments to the transfer, of land, are matters of paramount importance.

It has been already shown, by an extract from the Seventeenth Report of the Board of Public Works, that no change to a better system of husbandry can be expected from a pauper tenantry. It will ever be the duty of a wise Government to remove all burdens which press with actual severity on the cultivator of the soil. It is of the utmost importance that the means by which the annual produce is got from the land should be left unfettered. Whatever interferes with this tends to diminish that produce, and simultaneously to increase the demand upon the surplus, by throwing labourers out of employment. Rent is the surplus after all the expenses of cultivation, including a return for the 
tenant's capital and skill, are paid. That surplus must ultimately bear the burden of all taxation on the produce of land, for, without profit to the cultivator, there can be no permanent cultivation. If the taxation is laid directly on the landlord, the cultivation of the land will still go on, however burdensome that taxation may be.

It can scarcely be believed that, notwithstanding these obvious truths, the tenant's capital in Ireland has, by repeated acts of the Legislature, been made responsible for ALL the expenses of the county, and primarily for the entire support of the poor. The fearful ratio in which these expenses have increased during the famine has been already shown in the case of the county of Limerick, where, in the present year, a sum of $£ 181,638$, in addition to what the same rates amounted to in 1845 , is made a first charge on the capital of the tenant! And yet the rate-payers have but a semblance of control on the amount of county cess, as it is in the power of the gentry, who, as magistrates, are ex officio members of the sessions at which such control is exercised, to step in and outnumber the representative ratepayers.

No one, therefore, can wonder at the entire prostration of the occupying farmers in the West of Ireland. To relieve them from this unjust burden, and to encourage tenants of capital, either from other parts of Ireland, or from this country, to embark it with safety there, it will be necessary to TRANSFER THE GRAND-JURY TAXATION, INCLUSIVE OF THE LABOUR-RATE, FROM THE 
TENANT TO THE LANDLORD. * Whether it may be a prudent act of clemency, on the part of the Government, still further to abate the amount of repayments for labour-rate, in consideration of the unparalleled calamity, and the comparatively unproductive character of the works, it will be for the wisdom of Parliament to decide.

To this proposal it will be answered, that the countyrates are borne by the tenant in England. True; but public opinion there prevents an undue advantage being taken of the tenant. There is not the same suicidal competition for land, nor any of the circumstances which force that competition. Rents, therefore, are fixed, after a full deduction for rates. It has been already shown, that this has hitherto been quite impossible in Ireland. In Scotland, the tenant pays only one half of a very moderate poor-rate, a share of a trifling roadrate, amounting often to less than $1 \mathrm{~d}$. per pound, and no county-rates or expenses whaterer.

The adoption of this change, besides affording security to tenants of capital, would in the end, I am persuaded, be conducive to the true interests of the landlord. It would insure the watchful superintendence of the expenditure by the most educated class in the country, - the

* It would, of course, be right to guard the proprietor against any injus. tice in this change on the part of holders of beneficial leases. If, for instance, a man held an old lease "for ever," at a rent of 10 s. an acre, and the land was now worth 40 s., he would be allowed to deduct from his head-rent only one-fourth of the rate, that being the proportion due by the principal landlord. And in all current leases, it would be equitable that the tenant should continue liable, during their currency, for so much of this rate as was payable by him at the period of his entry. 
very men who are most deeply interested in the right application of the funds, and least liable to the influence of private jobbing in the works to be performed. The improvement of access to farms and markets, the discouragement and punishment of crime, the support of fever hospitals and dispensaries, the patronage of the public offices of the county, are surely the true business of the landlord. They are matters of such importance, that they require a degree of intelligent supervision, such as the landlords only have time for. This is at present both their duty and their privilege, and it needs only the stimulus of self-interest to make it be heartily performed.

To the want of such a stimulus may be owing much of the ABSENTEEISM, which has so long contributed to drain the resources of the country. An Irish landlord, with no direct interest in the county business, no improvements proceeding on his own estate, a competition for his land which made it far more profitable to him to let it than farm any of it himself, had very little inducement and no occupation whatever to keep him at home. Let him feel the pressure of mismanaged rates, and he will awake to the necessity of learning his own business. Living among his tenantry he will acquire a taste for country affairs, softening by his intercourse the asperities unhappily too common in Irish social life, promoting the views of improving farmers, and teaching all classes, by his own example, the inestimable value of humanity, integrity, and TRUTH.

With regard to the POOR-RATE, there are reasons for dividing this burden which do not apply to the county 
expenses. By making the farmer liable for a share of the rate, you are assisted by his personal knowledge in detecting the deceptive statements of claimants for relief, while you make him feel the pressure, which he himself causes by unwisely dismissing his labourers during a temporary "dulness of times."

A measure which should secure payment to outgoing tenants for UNEXHAUSTED IMPROVEMENTS, would greatly encourage the expenditure of capital by farmers, and their active co-operation with the landlord in all improrements. I do not allude to such a "tenant right" as is sometimes claimed, where very often no improvement whatever has been made by the occupying tenant, and yet he conceives himself entitled to a right of property, which he has never contributed anything to create; but to that custom which has arisen in Lincolnshire, and some other English counties, of paying a tenant for such improvements as can be ascertained to be left by him in the land when he quits the farm, thus encouraging the most perfect husbandry to the very close of each man's period of occupation. In regard to improvements of a permanent character, I think it is a better system, as I will have occasion afterwards to show, that these should be wholly provided by the landlord.

For these it might be advisable to extend the Land Improvement Act, so as to include FARM-BUILDINGS, with such restrictions as should guard against extravagant outlay, or indeed any outlay unless it could be clearly shown that other active operations in husbandry were to be followed out. Without that, such expenditure 
would yield no return; with it, probably no other permanent outlay would be more remunerative.

I do not disguise from myself the very grave liability which this country would assume by pledging itself for the safety of the enormous population of the West of Ireland. According to the census of 1841, the population of Connaught was $1,418,359$. The proportion of the people for all Ireland engaged in agriculture was 66 per cent, and the proportion is very probably greater in Connaught, as there is scarcely any other industry in that province. Taking it, however, at 66 per cent, this would give a population of 936,408 persons, or 187,281 families, wholly dependent on the culture of the soil. The total number of acres under crop in 1848, including corn, green crops, meadow and clover, was 619,000 . Suppose these were cultivated on the most approved system of modern farming, with an expenditure of 40 s. per acre in labour, (wages 10d. a-day,) they would afford employment to 99,040 labourers, heads of families, representing 495,200 of the population. And assuming that, by such a change of system, the agricultural population were to divide itself into employers and labourers, in the same relative proportions as in Scotland, there would remain in Connaught upwards of

* It is here necessary to point out an apparent inaccuracy in Sir Robert Kane's valuable work on the Industrial Resources of Ireland, p. 312. He there states that Professor Low, in his work on agriculture, gives some estimates, from which it results that a 500-acre farm yields an amount of occupation equivalent to the employment of twenty persons throughout the entire year; and upon this he founds an argument, showing the inapplicability of the large-farm system to Ireland. He overlooks the fact, that these twenty persons are heads of families, and represent one hundred individuals; and this mistake leads to a conclusion involving an error of $2,880,000$ of the 
50,000 agricultural labourers, for whom employment would still have to be found.

The following table, compiled from the returns of the census of 1841, shows the relative proportions of population to arable land in Scotland, England, and Connaught:-

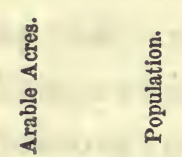

Scotland, 220 per 100 of which England, $175 \quad \ldots \quad 100$ Connaught, 150 ... 100

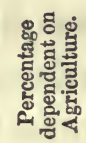

27

25

66

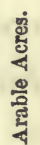

being 814 for each

$700 \quad 100$

$\begin{array}{llll}\ldots & 227 & \ldots & 100\end{array}$

Making every allowance for the land to be made arable by the arterial drainage, (which may add onetwentieth to the available land,) there still remains an alarming disproportion between the West of Ireland and Great Britain. And an immense influx of capital must take place, before Connaught is put on a level with this country in the materiel necessary for an equal development of her agricultural resources.

But, in effecting the preliminary steps for that purpose, there will be a great demand for labour-less or more, of course, in proportion to the comprehensiveness, or otherwise, of the scale on which it is carried on. It

population. I do not, however, wish to contend for the entire adoption of the large-farm system in the West of Ireland. It led to great results in Scotland, and the east and north of England, while prices of corn were high. But large farms, with corn for their main staple, are not now found profitable. Green crops and stock have become of, at least, equal importance; and the more elaborate cultivation and management required by them, as well as the greater capital necessary, have a sure tendency to lessen the demand for large farms, and gradually to lead to their subdivision into an extent more in proportion with the capital of their occupants. 
may be possible to operate on such a scale as shall absorb the greater proportion of the labourers; and it is conceivable that this might continue till the whole arable land was so improved as to be capable of affording regular employment to the entire agricultural population.

This assumes that that population does not at the same time increase in an equal ratio. "A tendency to increase can exist only with a power to spread; when the power to spread ceases, there begins a tendency to decay." * The discontinuance of con-acre, and the payment of wages in cash, will unquestionably assist in directly producing this result; while, indirectly, the circulation of money will encourage many of the people to become bakers, butchers, shopkeepers, tailors, shoemakers, carpenters, \&c., and thus tend, in the course of time, materially to alter the proportion of the population entirely dependent on agricultural employment. $\dagger$

It also assumes an amount of capital at once expended in the permanent improvement and cultivation of the soil, (landlord and tenant's capital,) such as has been effected by the slow but steady progress of years of laborious accumulation in this country. Under the most favourable circumstances, it will be a work of time also in Ireland, and consequently a large proportion of the population of Connaught must in the mean time be supported from other sources.

* Mr Hickson on "Laws of Population," in Westminster Review, for October 1849 .

+ This process has been going steadily on in Great Britain, where the proportion dependent on agriculture in 1811 was 35 per cent, and in 1841 was only 25 . 
The disproportion between population and employment is at present of such magnitude as to put it quite out of the question for the country to right itself, unaided. If left to do so, nature will soon restore her own equilibrium ; but the very thought of such a crisis is too hideous for a civilised nation to contemplate for a moment.

Sooner or later we must give effectual aid to the West of Ireland. Individual immigration by capitalists or farmers, however excellent, is too slow a remedy for the disease ; nor can the ordinary action of Government cope with such extraordinary circumstances. A COMPREHENSIVE SCHEME, LIKE THAT DEVELOPED BY SiR Robert Peel in the last session of parliament, is ABSOLUTELY NECESSARY FOR THE SAFETY OF THE WEST of Ireland. 


\section{H A P T E R XI.}

WHAT IS NOW BEING DONE FOR IRELAND-BOARD OF PUBLIC WORKSROADS, PIERS, ARTERIAL DRAINAGE, LANDED PROPERTY IMPROVEMENT, FISHERIES-NATIONAL SCHOOLS-STATISTICAL RETURNS OF AGRICULTURAL PRODUCE-AGRICULTURAL INSTRUCTORS.

I CANNOT conclude this volume without shortly referring to some of the many excellent measures which I saw in operation for the improvement of Ireland. These consist:

1. Of the improvements effected under the Board of Public Works.

2. The schools under the management of the commissioners of national education; including also, agricultural schools, model farm-schools, workhouse schools, and schools of industry.

3. The statistical returns of agricultural produce collected by the constabulary.

4. The appointment of practical agricultural instructors in different districts, under Lord Clarendon's letter.

The Public Works under the charge of the Board comprise-

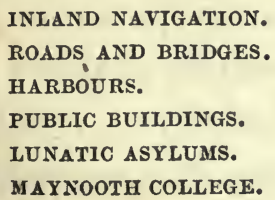

NEW COLLEGES, -BELFAST, CORK, AND GALWAY. PIERS AND HARBOURS. DRAINAGE. LANDED PROPERTY IMYROVEMENT. FISHERIES. 
The expenditure under these different heads is detailed in the 17th Report of the Commissioners, where the objects of the several items are explained.

The "Roads and Bridges" include the construction and maintenance of 1046 miles of roads now available for public traffic through poor and uncultivated districts.

The "Public Buildings" include the charge and erection of Government buildings in and near Dublin ; Dublin General Prison for Convicts ; Central Criminal Lunatic Asylum; Queen's Colleges; Maynooth College; Lunatic Asylums; Customs buildings ; Constabulary buildings.

"Piers and Harbours." The applications received by the commissioners for aid towards the construction of these, have been 134 in number. Grants have been sanctioned towards 45 .

Drainage. Under this head most important information is given as to the execution and progress of the arterial drainage of Ireland. From the flatness of a great portion of the interior of that country, an immense extent of the low-lying lands were annually subject to floods, which rendered all individual attempts at improvement impossible. To this natural difficulty was added the artificial obstructions made by unsuitable bridges and their approaches, encroaching upon the water-way of rivers and streams. These injudicious erections reduced the natural scouring. power of the rivers, and gradually led to the formation of shoals and deposits; while every addition to reclamation, improved drainage, and cultivation of the higher districts, brought 
down an increased volume of water, and a fresh accumulation of deposit.

To remedy this state of matters, loans have been granted, to be expended under the superintendence of the Board. Works have been commenced, considerably advanced, and some carried on to completion, or nearly so, in 101 districts, extending into or through nearly every county in Ireland. In these, the area of land drained, or in the course of being drained, comprises 239,922 acres, and a length of 993 miles of rivers or main drains, and 172 miles for navigation, at a cost exceeding $£ 600,000$. The works having been undertaken for the twofold purpose, 1st, of their own utility as works of improvement; and $2 \mathrm{~d}$, as a means of affording relief, by reproductive employment, to the distressed labouring classes,-as many as 20,000 men were daily employed during part of 1847 , and 17,000 a-day during part of 1848. The following extract refers to the works executed in Connaught, and more particularly applies to the improvement of a district treated of in the foregoing pages.

"The works were last year commenced in the extensive districts of Loughs Corrib, Mask, and Carra, in the counties of Galway and Mayo. The object proposed is, in addition to the drainage of extensive tracts of low lands, the connexion of Lough Corrib with the sea, by means of a navigable canal through the western part of the town of Galway, and a navigable connexion through a very difficult line of cavernous rocky country between Lough Corrib and Lough Mask-thus making a continuous line of navigation of about fifty miles from the 
sea at Galway to Maam in Joyce's country, and by Cong to Ballinrobe, and within a few miles of Castlebar in Mayo.

"Combined with these objects of navigation and drainage is a very important measure of improved manufacturing power at Galway, applied for under the provisions of the Drainage Acts, by the parties possessing the water-power at present existing, the project involving the remodelling and increasing nearly all the mill sites in Galway, and the formation of new sites; to nearly all of which it is proposed to make available the full fall between Lough Corrib and the level of the sea, by means of main conduits, on each side of the river Corrib, whereby each mill-owner may draw his supply of water-power directly from Lough Corrib, which contains an area of 43,480 acres of water.

"In connexion with this latter object it may be observed, that water-power can, under these arrangements, be made available-if the necessary funds be provided by the town-for supplying the highest parts of Galway with water for all sanitary purposes.

"Looking to the natural position of the place as the terminus for the important line of railway from Dublin to the west, and as the natural market centre for the vast extent of country around it on every side, but especially to the north-west, it appears difficult to set a limit to the advantages of opening the great natural navigation of the lakes in question, with the important manufacturing power thus contemplated to be conferred on Galway, taken in combination with the extensire 
measures of drainage, not only along the Lough Corrib district, but in the various other adjacent drainage districts of Oranhill, Dunkellin, Lavally, Turloughmore, Monivea, Dunmore, Shrule, Kilmaine, Lough Mask, and river Robe."

The advantages of the drainage, increase of waterpower, and connexion of Lough Corrib with the sea for purposes of navigation, cannot be over-estimated. The lowering of the level of Lough Mask, and the consequent drainage of the adjoining country and the basin of the river Robe, are also matters of the highest importance; but the extension of the navigation between Lough Corrib and Lough Mask, by means of locks and a canal cut through the solid limestone rock, however desirable, will, I fear, be attained only at a cost disproportioned to the ultimate advantage. The navigation for steamers must stop at Cong, at the head of Lough Corrib ; and the distance to this point from the surrounding country, including both sides of Lough Mask, is not great.

The peace and good order of the country have been greatly promoted by the execution of these works. The system of task-work introduced by them, with its stimulus to energetic labour, the regular cash payments, and the evident utility of the works, have all enlisted the confidence of the people. During the excitement of last year, the regular employment afforded by them is understood to have been the means of preserving the peace of many districts, besides lessening the temptation to crime.

The following table shows the satisfactory results in 
two cases in which the operations have been completed :-

\begin{tabular}{|c|c|c|c|c|c|c|c|}
\hline 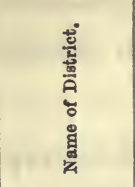 & 宽 & 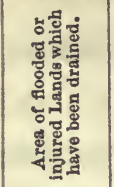 & 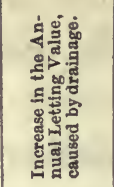 & 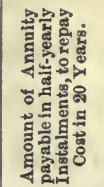 & 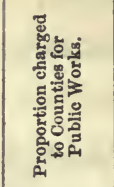 & 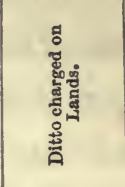 & 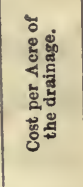 \\
\hline $\begin{array}{l}\text { Blackwater, } \\
\text { Oranhill, }\end{array}$ & $\begin{array}{l}\text { Kildare and } \\
\text { Meath, } \\
\text { Galway, }\end{array}$ & $\mid \begin{array}{rrr}\text { A. } & \text { R. P. } \\
3827 & 218 \\
974 & 0 & 16\end{array}$ & $\begin{array}{ccc}\mathscr{E} & \text { s. } & \text { D. } \\
1034 & 7 & 9 \\
315 & 10 & 1\end{array}$ & $\begin{array}{ccc}£ & \text { s. D. } \\
382 & 4 & 1 \\
139 & 17 & 7\end{array}$ & $\begin{array}{rrr}£ & \text { s. } & \text { D. } \\
183915 & 9 \\
190 & 16 & 2\end{array}$ & $\begin{array}{rrr}£ & \text { s. } & \text { D. } \\
10,276 & 0 & 9 \\
3681 & 0 & 0\end{array}$ & $\mid \begin{array}{lll}£ & \text { s. } & \text { D. } \\
2 & 13 & 6 \\
3 & 15 & 7\end{array}$ \\
\hline
\end{tabular}

The benefits to the country generally of these great drainage operations, are of the highest importance. The area of flooded and injured lands, estimated to be drained or improved, amounts to 300,000 acres, "that for a large portion of the year were only the fit resort of wild ducks," and are now expected to be converted into rich and fertile plains, fresh and unexhausted. The general amelioration of the climate by the drainage of such an extensive evaporating surface may be expected to be very considerable. In the counties of Mayo and Galway, I had an opportunity of riding over many hundred acres of fine alluvial land, laid dry by these works, and can therefore testify to their value. In some of them the depth of the main drains had not secured a sufficient outfall for the perfect drainage of the adjoining lands; and wherever this is the case, the effect produced will fall short of what the owners were entitled to expect when they pledged themselves for the repayment of the sums advanced. But, on the whole, the system is one peculiarly adapted for the management of a Government board, involving as it does such a multiplicity of interests,-mill-owners, county bridges, 
fisheries, navigation, rights of neighbouring proprietors, all of which could be reconciled only by an impartial central authority; while the immense magnitude of the works, involving great engineering skill and appliances, and uniformity of operation, would have set at defiance all chance of benefit from individual energy. For these reasons, a similar scheme might with great propriety and advantage be applied on the British side of the Channel.

LAND IMPROVEMENT is the next branch in which most important benefits are being produced under the management of the Board of Works. For this purpose they grant loans to proprietors, repayable in twenty-two instalments of $6_{2}^{1}$ per cent, for thorough drainage, fences, sub-soiling, clearing land of stones, making farmroads, and irrigation, for which purposes loans have been sanctioned to the amount of $£ 1,420,600$. The progress of the works has been very satisfactory.

"At the commencement, even in our most advanced districts, the works were not conducted in the regular and systematic manner necessary to insure ultimate success and a beneficial return in proportion to the expenditure contemplated by the Act. The superintendents employed by many of the proprietors had never previously executed, or seen works of thorough draining completed, according to the modern system, and many did not think it necessary to adhere strictly to the plans laid down, or the dimensions of the drains given in the specification for their guidance; but through the means of frequent inspections, and the 
instructions given on each occasion, the works gradually assumed a different character ; and the overseers, gratified by their own success, became zealous in the performance of their duty. Even in the most remote and backward districts of the west, drainage works are now being executed in a manner which two years ago would have been considered in our best districts worthy of imitation."

And in our best districts, too, in Scotland. The care and attention paid to the out-falls of main drains, and the security with which the junctions with the submains are formed, as I witnessed both in Mayo and Galway, are worthy of imitation anywhere.

The number of acres that have been thorough drained under the Land Improvement Act, from the commencement up to 31 st December 1848, amounts to 38,860 , giving an average cost of $\mathfrak{\Sigma} 4,10 \mathrm{~s}$. an acre ; and a great portion of the drained land has also been subsoiled.

In regard to fencing, it has been recommended to divide each tract into a number of moderate-sized farms, according to the quality of the land, surrounding each farm with a fence, and then erecting subdivision fences. In the western localities, where the climate is considered more favourable for stock than cereal crops, and where drained lands continue to improve in pasture for a certain time, eight, or even more, divisions are recommended to be made; while in the middle and eastern districts, six equal divisions are thought most suitable for a regular system of rotations.

The soils requiring draining are principally clayey loam, intermixed with limestone pebbles, in which drains 4 feet in depth, and from 36 to 45 feet apart, 
are found effectual, especially if the operation of subsoiling, either by plough or spade, is at the same time performed. Subsoiling by the spade is an excellent operation, and can be very cheaply executed by contract; in some districts for $£ 2$ an acre, to a depth of 18 inches; though anything below $£ 3$ an acre, for effective subsoiling to that depth, is believed to be an excellent and remunerative expenditure.

In the clay-slate districts of the west of Clare, west of Limerick, Kerry, and North Cork, I should fear the draining would not be perfectly efficient with drains at a much greater distance apart than 24 feet.

There are now tileries, in forty-seven different localities in Ireland, where pipe-tiles of excellent quality are manufactured. To the increase of this branch much encouragement should be given. I have no hesitation in expressing my opinion of the superiority of tile over stone drainage, especially on level land, and particularly in regard to the better adaptation of the tile for circulating air through the subsoil, the ameliorating effects of which are now recognised as a most important adjunct to thorough drainage.

The cost of progress inspections amounts to $£ 1,16 \mathrm{~s}$. per cent on the expenditure, which is thought very moderate, when it is considered that the works are scattered over every part of the country, even to the most remote of the western promontories, while the inspectors had frequently to deal with proprietors who were not men of business habits, with unskilful overseers, and, in the western districts, with labourers whose spirit of industry and self-reliance had been deadened, 
if not destroyed, by the pauper dole of food, or by pauper employment. Employment has been afforded by the works to upwards of 20,000 labourers constantly during the past year, the larger proportion of which has been in the more distressed districts of the country.

"The effect of this Act in directing the attention of proprietors, previously careless on the subject, to agricultural improvement, is very remarkable ; and every one connected with the district has observed the change of habits which has taken place among many of the leading sportsmen, who now vie with each other in attention to farming improvements; and gentlemen of different estates, who formerly employed labourers as a matter of duty, now take a personal interest in the works." - Report of Mr Prendergast for the county of Leitrim.

In the county of Galway, Mr Irvine says :"The most remarkable portion of the works is the reclamation of more than 1000 acres of bog and moor, which, by draining, levelling, and gravelling, have, at a cost of $\mathfrak{L} 4,14 \mathrm{~s}$. 6 d. per acre, been increased in value fully 7 s. per acre, making a return exceeding 8 per cent on the amount expended. The successive operations by which the improvement has been effected were, first, the dividing the several tracts proposed to be reclaimed into fields varying in extent from 3 to 15 acres, by open drains 6 feet in depth; the surface of the bog then received a general levelling, after which, a top-dressing of 120 cubic yards per acre of clay or clayey limestone gravel was laid on and carefully spread." 
Many more instances equally instructive might be given of the benefit conferred on the country by the Land Improvement Act. These are thus summed up in the Report by the Commissioners.

"Three striking effects have been produced :-

"1. The proprietor who obtained the loan has gradually become sensible of the great pecuniary advantage to be derived from thorough draining, and in consequence has used his best exertions to carry out the works successfully.

“2. Excellent cereal and green crops have been produced on land previously of little value. And,

" 3 . The labourers have been weaned from the old system of day labour, which always engenders idleness, and have adopted piece or task work, according to which each man receives the just reward of his industry and exertion, and is paid in proportion to the amount of work done."

Conducted, as this department of the public works is, under the very able direction of $\mathrm{Mr}$ Griffith, it cannot fail to be attended with the most important benefits to Ireland.

Fisheries form another department under the charge of the Board of Works. The Commissioners recommend that direct Government interference be confined,

1. To the maintenance of peace and order among the fishermen, and matters immediately connected therewith.

2. To the provision of suitable public accommoda- 
tion and protection by harbours, landing-places, and roads for the persons engaged in the trade; and,

3. To any assistance which can be given through existing establishments to promote practical education in the habits, modes of capture, and curing of fish.

These, they admit, will effect but little, without a steady market and a remunerating price. "These attained, boats, gear, tackle, and comfortable habitations will soon be found; and self-interest will powerfully aid education to banish ignorance and prejudices, which are now rather unwisely charged as causes of deficient fisheries."

To encourage the fisheries by providing a market, the Commissioners established a number of curing stations on the West coast, which have since been made over to private parties, to be carried on as private mercantile speculations. Their example has been extensively followed. It has been found that in these most remote places, fish can be cured in a manner equal to any produced in any other country; while the curing-house supplies the want of a local market for surplus produce. The trade has been thus commenced, and the foundation laid for permanent improvement.

The National Schools of Ireland form another great branch of the means in operation for the improvement of that country. The number of schools open at the close of 1848 was 4109 , and of pupils on the rolls 507,469 ; the increase of attendance during the year, as compared with 1847 , amounting to 104,837 children. The amount of salaries paid to national teachers for the 
year, was $£ 57,013,10$ s. $8 \mathrm{~d}$. The system of paid monitors has been tried with much success: the amount paid under this head, for 1848 , was $\$ 924$. The teachers are divided into three classes, with different scales of salaries; each teacher being assigned to the class to which he is found qualified on an annual examination by the head inspectors.

The national school-books used are so much valued, that a large demand for them has arisen in England, Scotland, and the colonies.

The daily average attendance in the model schools of Dublin for the year, has at various times considerably exceeded 1000. During the year, 267 teachers were trained and supported at the public expense, of whom 177 were males, and 90 were females : 11 were of the Established Church, 37 Presbyterians, and 219 Roman Catholics. The total number of male and female teachers trained from the commencement has been 2311 .

The greater number of the workhouse schools have been placed under the superintendence of the Commissioners of Education, who remark, in their report, "that the Boards of guardians of the different Unions comprise Protestants and Roman Catholics, and have amongst them men of the highest rank and station; that the schools are attended by Protestants and Roman Catholics indiscriminately ; and that the duty of giving religious instruction to those of each creed belongs to a chaplain of their own communion. That here, therefore, we see the national system carried into complete effect; that here we see how peculiarly adapted it is to the circumstances of Ireland; and that here, too, we 
see how decidedly it carries the opinion of the country with it."

Besides schools for general education, there were also 50 agricultural schools in connexion with the Board at the end of 1848 .

The model farm at Glasnevin, and school of training for agricultural teachers, under the skilful management of $\mathrm{Mr}$ Donaghy, has been already referred to. Much interesting information as to this and the other agricultural model schools of Ireland, will be found in the able report of Dr Kirkpatrick, the agricultural inspector under the Board, at page 252 of the appendix to their fifteenth report.

The establishment of model agricultural schools, the commissioners find, will be attended with far greater expense than was at first anticipated. It may be doubted whether there is really any great practical advantage to be obtained by teaching agriculture as a branch of the national school education. In fact, I have never been able to understand why agriculture should form a subject of elementary education, any more than baking or brewing, tailoring or shoemaking, or any other of the usual occupations of industry. A few successful and intelligent practical farmers in a district, carrying on their business on strict principles of commercial profit, would form, in my opinion, more useful instructors in agriculture to their neighbourhood, than is at all likely to be attained by the somewhat theoretical farming taught in an elementary school.

Where, however, the schools are united with considerable farms, like Glasuevin and Templemoyle, the 
practical instruction afforded must be of the most valuable kind. Young men, who have already obtained an elementary education, go there to learn the business of life; and from centres such as these are diffused over the country a class of intelligent, educated, active young men, fitted admirably to take the management of farms on their own account, or to act as land-stewards for others. The extension of such schools and farms throughout the different districts of Ireland is undoubtedly of the first importance.

The total expenditure by the commissioners for a year, up to 31st March last, for purposes of education in Ireland, was $£ 127,777,7 \mathrm{~s}$.

The Returns of Agricultural Produce form another of the important series of measures now in operation for the improvement of Ireland.

They are compiled from information collected by the Constabulary force from every district of the country; and great care has been taken, both by establishing a variety of checks, and by local information, to insure very great accuracy in the performance of this duty. The power of comparing the detailed extents, in the different returns, with the field divisions in the ordnance maps, insured a degree of correctness probably unattainable where the ordnance survey has not been made.

The returns show, 1st, the "Extent of land under crop," (specifying each kind of crop,) the "Quantity of produce," the "Area in statute acres," the "Poor-law valuation," and the "Population in 1841," of each county, of each province, and of the whole country. 
$2 \mathrm{~d}$, "The stock on holdings above one to five acres," (distinguishing each kind of stock,) "Ditto above five to fifteen acres," "Ditto above fifteen to thirty acres," "Ditto above thirty acres," "Ditto householders and holdings not exceeding one acre;" also for each county, province, and for the whole country.

$3 \mathrm{~d}$, The same information on both heads is given for. each union in Ireland, and for each electoral division of such union.

In this most important branch of statistical information, viz., correct returns as to the food of the people, Ireland has taken the lead of Great Britain. The whole quantity of food in that country can now be accurately estimated, and the material progress or declension of the country be at once ascertained. A great variety of facts may also be elicited by an attentive examination of these returns. One or two of these may be here noticed.

Four of the best and four of the worst circumstanced Unions in Ireland show the following comparative amount of grain and potatoes to each person :-

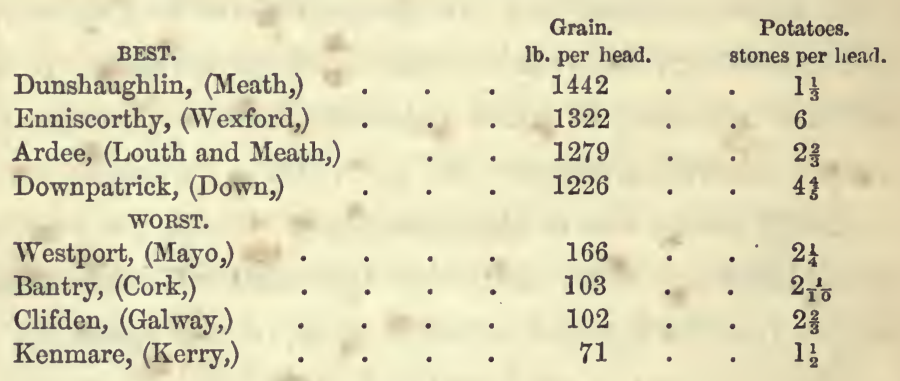

We thus learn at once the disproportion between population and food, in the worst, as compared with the 
best circumstanced Unions, and find that the fearful shortcoming in grain, in the most distressed, is not in the slightest degree counterbalanced by a larger proportion of potatoes per head.

Again, it has been already shown (p. 130) from these returns, that the average proportion of people to acres of grain, in the four first-mentioned Unions is 114 to 100 acres, and in the four last 1345 to 100 acres; and it might be reasonably inferred that, in the latter, with such an overabundant population, there could be little occasion for horse labour at all. On asking this question of the returns, we receive the following reply:The arerage number of acres in cultivation to each horse in the first four Unions is . . . . . . 8 In the last four . . . . . . . . . . . . 4

So that, while the competition of labourers in the worst is as 12 to 1 in the best, the displacement of horse labour by this competition is only as 2 to 1 ; and even that may be accounted for by the larger proportion of potato cultivation, in the worst, requiring more manual labour.

It appears from these returns, that there is a marked decrease in the number of small holdings, and an increase of the larger ones, showing a decided progress in the consolidation of farms.

They show also a decrease of 4108 acres of flax, (equal to one-thirteenth of the whole breadth cultivated,) as compared with the previous year.

The following particulars with regard to stock in Connaught are interesting. Last year, as compared with 1847 , shows a decrease of one sixth in the horses, 
and between a fourth and a fifth in the whole sheep stock; while there has been an increase of about one fortieth in the "mules and asses," one ninetieth in cattle, and about one fourth in pigs. The increase in pigs is partly accounted for by the increased breadth of potatoes cultivated in 1848 as compared with 1847 , that having occupied 109,012 acres in 1848 , and only 29,417 in 1847 .

The want of -statistical information of a similar character to this, has long been felt in Great Britain. The importance of correct data as to a matter of such vital consequence as the food of the whole nation, would certainly warrant the necessary expenditure. Nor does it seem that that should be great. In Ireland advantage has been taken of the presence in every district of that efficient body, the Constabulary force, through whom are furnished the returns on which these statistical tables are founded. We have no similar body in this country; but the same information might be obtained, at very moderate cost, through the poor-law officials, now stationed in every parish in Great Britain.

The appointment of Agricultural Instructors is a plan which originated with his Excellency Lord Clarendon, who for each of the last two years has placed $£ 1000$ at the disposal of the Royal Agricultural Improvement Society of Ireland, to aid them in this object. - Subscriptions were likewise opened, and contributions sent in, by local agricultural societies, and a fund of $\$ 2583$ collected. To each of fifteen local societies, which had contributed a portion of the ex- 
pense, one agricultural instructor, qualified to teach the small farmers practically, was sent; and to twelve districts in the more distressed parts of the country, instructors were sent gratuitously.

The instructors are directed to devote their time exclusively to the instruction of the working farmers, stimulating them to habits of industry at all times in the year ; showing them the advantage of deep digging, the preparation and collecting of manures, the necessity of house-feeding stock, the advantage of rotation of crops, the benefits attending the cultivation of green crops, and the culture of flax. They are directed, as far as practicable, to superintend personally the several operations on the farms in their districts, from time to time; and to furnish reports monthly.

The benefits conferred by this method of practical instruction are said to be very considerable, though much marred, in the most distressed districts, by the poverty and consequent inability of many of the working farmers to carry out the better plans recommended. Where the people have not become hopeless, the instructors are more successful; and the extent to which the people are benefited by this method of imparting information, can be accounted for only when the great ignorance of this class, as to the advantages of good cultivation and economy of manure, is understood. The admirable example set by his Excellency the Lord Lieutenant should be followed by the proprietors of large estates; for, if the instructor was seconded by the means which the landlord ought to contribute to enable his poor tenantry to adopt better 
plans, the advice he would then give would be listened to with a more reasonable prospect of improvement. The necessity for the system at all has arisen chiefly from the want of practical knowledge on the landlord's part, and the same on the part of his agent; as otherwise they never would have permitted their tenantry to fall so much behind in the most ordinary agricultural knowledge.

The reader who has followed me through the foregoing details, will see that very much is being done to aid the material improvement of Ireland. The whole mechanism of a perfect body is, as it were, being put into order by the directing hand of Government. The brain is being prepared by national schools, colleges, and agricultural instruction; the bones covered with sinews by the means of communications, promoted by the Board of Works; the arteries and veins are represented by the arterial and thorough drainage of the country; while the pulsations which indicate health or disease are obtained by the statistical returns of food. To set all in vigorous motion, a full heart of capital is required, whence would issue the life-blood itself which is requisite to the healthy action of the whole frame!

Whilst there can be little doubt that many of these improvements have outrun the rate of individual progress in the country, and that the repayment by instalments of the outlay incurred, will only add more to the burdens of the already deeply-embarrassed proprietor, who has no means left to develop the additional resources thus laid open to him, it is very different with the pur- 
chasing capitalist. He goes to a country where the imperial resources of a great state have been lavishly expended, in opening up excellent roads in all parts of the country, and in laying dry, by arterial drainage, the low-lying lands which individual effort could not have coped with. In short, he would have little more to do than to confine himself to the improvement of his own estate, as he would find all those channels already provided by the care of Government, which in other countries have been the slow growth of years. 


\section{CHAPTER XII.}

FARM-BUILDINGS-ECONOMICAL PLAN OF, DESCRIBED-ESTIMATE AND COST -EXTENSION OF LAND IMPROVEMENT ACT-NECESSITY OF DEFINING PROPORTIONS REPAYABLE BY LANDLORD AND TENANT RFSPECTIVELYGOVERNMENT LOANS RENDERED NECESSARY BY ENCUMBRANCES AND ENTAILS-UNSOUND STATE TO WHICH THESE HAVE LED-FREE TRANSFER OF LAND THE ONLY REMEDY-EXPEDIENCY OF GOVERNMENT LOANS IN THE MEAN TIME.

THE general want of suitable farm-buildings in the West of Ireland has already been frequently referred to. An improved system of agriculture cannot be commenced without the accommodations for stock, crop, and manure which are necessary for carrying it out. Plans of farm-buildings are frequently conceived in such an expensive style as to impose a very heary annual charge for interest, or even to deter a proprietor altogether from venturing on their execution. And in a country where everything has to be done, a landlord, however well intentioned, finds his means totally inadequate to the general erection of any expensive system of housing.

This I found, in the West of Ireland, a very common answer to any complaint of inadequate farm-buildings. The plans usually recommended by architects, or in books, such as Low's Practical Agriculture, or Stephens' Book of the Farm, are of so costly a character, that 

Irish landlords say they cannot attempt them. An outlay, ranging from $£ 2000$ up to $£ 4000$ for the accommodation requisite for seventy or eighty head of cattle, fourteen horses, and corresponding implements and crop, involves a present outlay, and a constant charge, for which they can get no adequate return. Designs of a cheaper character are much sought for ; and having been frequently applied to for information on this matter, I have, with the assistance of my friend $\mathrm{Mr} \mathrm{M}^{\circ} \mathrm{Culloch}$ of Auchness, prepared the annexed Plan, which will be found to afford nearly the same accommodation, for, I believe, about one-third the expenditure of those already referred to.

The buildings of a farm are required to afford accommodation for the working stock, the rent-paying stock, feeding conveniences, the threshing of the corn crop, and the collection and manufacture of manure. They should be placed in the most central part of the farm, at which a constant supply of water for the stock can be insured. Advantage should be taken of water-power for machinery, if it can be got.

A level piece of ground should be chosen for the site of the buildings, in order that no unnecessary expenditure may be requisite in earth-work. And for the West of Ireland, the stables, as in the annexed plan, should form the west side; the barn, straw-house, \&c., the north side of the range; thus securing the shelter of the highest part of the buildings against the prevailing winds.

The farm-house, with dairy, \&c., are supposed to occupy the south front of the plan; but they are not 
included in the estimate ; nor are the labourers' cottages, which should be situated at no great distance from the farm-buildings.

It will be seen that this plan affords accommodation for ten horses and eighty cattle in stalls, besides implement-house, barn, granary, straw and chaff house, clover or turnip house, boiling-house, covered dung-house and tank for saving liquid manure, pig and poultry houses. It is suitable for a farm of 200,300 , or 400 acres, according to the proportions of tillage and the style of farming pursued, being sufficiently extensive for a 400 acre farm managed on the system described by $\mathrm{Mr}$ Stephens in his Book of the Farm, and not a bit too large for a 200-acre farm cultivated in the more improved system now believed requisite to ensure profit with a moderate scale of prices.

The preservation and accumulation of dung is the foundation of this system; and, accordingly, the plan includes a dung-house roofed over to prevent the action of the air and weather, and beneath it an arched tank capable of containing about 8000 gallons, into which covered drains, from the stables and cattle-houses, conduct the whole liquid manure. This is unquestionably the most important part of the whole farm-steading, and yet it is almost the only portion which is wholly omitted in the expensive designs already mentioned.*

The wheeling of the dung from the different stables and cattle-houses is so arranged, that the heaviest part

* For full particulars as to the mode of accumulating, mixing, and applying solid and liquid manure, the author refers the reader to his pamphlet on " High Farming," published by Messrs Blackwood. 
of the labour is brought nearest to the dung-house; the farm-stables, where each man carries out from two horses only, being the most distant. For the same reason, the turnip-house, and straw and boiling houses, are placed in the most convenient juxtaposition with the cattle-houses.

A considerable extent of granary room is shown on this plan, which may be divided for various purposes, according to the wants of the tenant.

Windows in the walls of the cattle-houses have been avoided, as leading to expense in lintels, corners, \&c. The access of light is equally secured, and at much less cost, by skylights in the roof. Ventilation is provided by large drain-tiles being built through the walls, one to every pair of cattle, a little above the ground-level, behind each row of cattle; while the escape of foul air is secured by an equal number of tile-holes, a little under the eaves, as shown at $b$ on the section of the plan.

It will be observed that the system of stall-feeding is that shown in this plan. A considerable comparative experience has convinced me that no other method will give equal accommodation for the same outlay; whilst I am also persuaded that, in regard to economy of food and litter, facility of labour in attendance, health and progress of the cattle, and systematic arrangement altogether, stall-feeding is superior to any other that has yet come under my notice. The progress of the soiling system, or house-feeding of cattle in summer as well as winter, will lead to a more general recognition of the superiority of stall-feeding, both from the neces- 
sity of economising litter, and the advantage of not wasting the labour of the cattle-feeders and others in traversing unnecessary distances while attending to the stock.

The east front of the plan is left vacant ; but it can be filled, as shown by the dotted lines, either with increased cattle-houses, or sheds for sheep-feeding, as may in the course of time be found requisite.

The cattle-stalls may be devoted either wholly to the feeding of cattle, to the accommodation of a dairy stock, or to a mixed stock of breeding, feeding, and dairy cattle.

The expense of erection will be very materially lessened by the use of pan-tiles for roofing; and for this reason the proprietor of an extensive estate would find it to his advantage to manufacture them on his own account.

The specifications for masonry, wood, \&c., are as follows :-

\section{Stable and Cart-shed.}

Masonry of walls, 22 inches thick. 12 barrels of lime to the mason rood of 36 yards square.

Joists, 9 inches by $2 \frac{1}{2}$ inches, 20 inches from centres. Flooring, $1 \frac{1}{8}$ inch thick.

Couples, 7 inches at bottom, 6 at top, $2 \frac{1}{4}$ inches thick.

Lath, $1 \frac{1}{4}$ inch by $\frac{3}{4}$ inch.

Cast-iron skylights, glazed.

Windows, glass above and sliders below.

Stall-posts, 6 inches square, divisions $1 \frac{1}{2}$ inch thick.

Manger, wood 1 inch thick. Heck sides, 4 inches by 2 inches.

Heck spars, 2 inches square. 


\section{Barn and Straw-house.}

Roofing, same as stable.

Sleepers, 5 inches by $2 \frac{1}{2}$ inches.

Flooring, $1 \frac{1}{8}$ inch thick.

\section{Cattle-Houses.}

Walls 20 inches thick. No windows in walls.

Couples, 6 inches at bottom, 5 at top, 2 inches thick.

Slating lath, $1 \frac{1}{4}$ inch by $\frac{3}{4}$ inch.

Stalling, posts 4 inches square. Division spar, 4 inches broad by 1 inch thick.

Soletree, $5 \frac{1}{2}$ inches by 4 inches.

Board on top of soletree to form feeding-trough, 6 inches broad by $1 \frac{1}{2}$ inch thick.

Lath for tiles, (if tile roof, $1 \frac{1}{2}$ inch by 1 inch.

Couples placed 2 feet 2 inches from centres for tile roof.

Do. 1 foot 9, do. slates.

\section{General Specifications.}

All doors to be 1 inch thick, with 3 bars, 7 inches by 1 inch.

Door styles, 6 inches by $2 \frac{1}{2}$ inches.

Feeding troughs bottomed with flooring tiles.

All paving executed with sea, or river, or suitable land stones. Tank, arched with common bricks, cemented with Roman cement, and bottomed with flooring tiles.

Iron gratings and cesspools for urine drains as shown on the plan.

\section{Estimated Cost.}

Wood, 1s. 6d. per cubic foot. Stone paving, 3d. per yard. Ridge-tiles for roofs, $2 d$. per foot. Lead for gutters and valleys, $5 \mathrm{lb}$. per foot, at $2 \frac{1}{2} \mathrm{~d}$. per $\mathrm{lb}$. Flooring tiles, $1 \mathrm{~d}$. each.

Building, including lime and sand, 56s. per rood, for stable, cart-shed, barn, and straw-house; and 54s. per rood for the remainder of the building.

Slater's wages, $11 \mathrm{~s}$. per rood. 
With the foregoing prices, and using a cheap description of slates on lath, called "Tons," of which one ton, costing 35s., covers twenty-four yards, the estimated cost of these farm-buildings is $£ 612$.

Roofed with pan tiles, (500 of which, costing 16 s. 6 d., cover one rood,) the estimated cost is $£ 478$.

These estimates allow no profit to the contractor, and assume the whole materials to be laid down free of carriage.

The propriety of extending the Land Improvement Act, so as to embrace the erection of farm-buildings, as one of the objects for which Gorernment loans should be made, has already been referred to. It seems to be assumed by the Deron Commission, that farm-buildings are not strictly a reproductive outlay, and they therefore do not recommend assistance of this kind to be given. Upon what grounds they formed that opinion, it is not for me to say. But I am quite sure that no improved course of agriculture can be entered upon in the West of Ireland, without building accommodations. It will be vain to drain the land, and fit it for the culture of green crops and grain, if no suitable housing is at the same time provided for the economical and profitable conversion of these into a marketable form.

The almost universal want of farm-buildings renders it impossible for the present proprietors to provide what is required at once, or for many years to come, if unaided by Government. A loan, repayable in twentytwo years, might be perfectly safe, if a limitation of 
rates is adopted. Without that, it would be clearly imprudent, in the more distressed districts, to lend money for this purpose on the security of the land.

But if any comprehensive scheme is adopted for the West of Ireland, this should form an important feature in the plan. The immediate employment provided would include masons, carpenters, nailmakers, sawyers, and a numerous class of tradesmen and contractors, who receive no direct benefit from the other operations going on at present under the Land Improvement Act. This would also benefit the towns and villages, and thus diffuse employment generally throughout the country.

The chief thing to be guarded against is, that landlords, already embarrassed, might still farther involve themselves, by becoming bound for therepayment of the Government loan, without having the capital necessary to turn the buildings to a profitable account. Very stringent regulations would be required to prevent such an occurrence.

In granting Government loans for the improvement of land, it is here necessary to remark, that Parliament committed an oversight in not assigning the proportions in which the instalments are equitably due by the landlord and tenant severally. The almost universal rule in Scotland has been to lay the whole burden on the tenant. There can be little doubt but that draining, if judiciously executed, will be profitable to a tenant, even at $6 \frac{1}{2}$ per cent, and that he would be quite right to take upon himself the whole $6 \frac{1}{2}$ per cent, (which includes principal and interest,) on obtaining a lease of his land for twenty-two-years, and on being guaranteed the difference of value which his farm would thereby be worth to 
the landlord at the expiry of his lease-that difference of value being the just property of the tenant, as it has arisen from his unassisted outlay and labour. But it is quite clear that, without such a guarantee, the landlord, at the end of twenty-two years, will receive an addition to his rental of $6 \frac{1}{2}$ per cent, on the amount expended in draining - a sum amounting to a fifth, a fourth, in some cases even a third, of his rental-obtained by him without risk or labour, and diverted from the returns justly due to the tenant, who has repaid the whole outlay. For the experience of the past does not entitle us to believe that landlords will refuse to avail themselves of the increased rent to be obtained at the end of an improving lease, even though that increased rent is the result entirely of the tenant's labour and capital. It may therefore be fairly concluded, that, if the operation is sufficiently remunerative to enable the tenant to repay the whole expense to the Government in the course of twenty-two years, the landlord will then divert into his own pocket the $6 \frac{1}{2}$ per cent hitherto paid to the Government. In short, the landlord who has had the shrewdness to apply for, and the good fortune to obtain, $£ 10,000$ or $£ 20,000$ of the public money for land improvement, and who has been able to persuade his tenants to pay the whole $6 \frac{1}{2}$ per cent, will at the end of twentytwo years just find himself a richer man by $£ 10,000$ or $£ 20,000$, though he has submitted to no present outlay or inconvenience to obtain this very important future advantage.

At the end of twenty-two years, no doubt, there will be repairs necessary to maintain the benefits of the out- 
lay, and for these the landlord is entitled to take some security. But it is quite unfair for Parliament to leave the tenant at the mercy of the landlord in this matter. The landlord says to his tenant, "I do not force you to take this loan: judge for yourself; but if you do take it, you must repay the whole." This places the tenant at a great disadvantage. He knows he cannot get on at all without drains, fences, and farm-buildings ; and rather than want them altogether, he accepts the landlord's terms. But why is the landlord allowed to make terms with the money of the State? That money is advanced for the general good, and all who participate in its advantages are entitled to pay for doing so.

It would, therefore, be an act of justice to the tenantry of both countries-at the least, to EXTEND THE PERIOD FOR REPAYMENT OF THE LOANS, and sO diminish the tenant's annual instalments.

In the present state of landed property in Ireland, these outlays cannot be made without the aid of Government. The advances of Government are charged on the land in spite of encumbrances and entails. The Government alone can do it with safety, and therefore the burden is laid on the Government.

Yet it is an unnatural and perilous necessity which compels a constitutional government to become a gigantic mortgagee; and it may undoubtedly come, at some future period of our history, to give to the executive a dangerous control over the aristocracy. Surely it would be a safer as well as a simpler remedy to remove all impediments, of whatever nature, to the free transfer of land, and thus to try whether there is 
not enough of private capital and energy to develop the natural resources of the country, which hitherto have been "cabined, cribbed, confined" in all that relates to the ownersbip and improvement of land.

The following statement* will show more clearly, at a glance, some of the liabilities to which the locking up of the land has led :-

For the four counties of Limerick, Clare, Galway, and Mayo, the annual rental of the land is Annual tithe rent charge, ․ $\quad £ 81,384$

Expenditure on poor for last year, 639,305 Grand-jury presentments, . 167,816

Labour-rate repayable annually for 10 years, Relief loans,

$$
\begin{array}{rr}
99,517 \\
\text { do., } \quad 23,237
\end{array}
$$

I have already shown that the enormous increase of the rates is driving tenants of capital out of the country, and that eventually the whole burden may fall upon the rental; and if to this be added the annual liabilities of proprietors for encumbrances of every kind, to private mortgagees, whether left to them by their predecessors or created by themselves, we cannot wonder at the present bankrupt state of so many Irish proprietors.

We must therefore keep steadily before us the limited interests of landlords in their estates, (whether under entails $\uparrow$ or encumbrances,) as undoubtedly the master

* For particulars, see Appendix, Nos. 2, 4, 5 and 6.

+ "As to landlords allowing the tenants for improvements upon the farms, that would be a most desirable thing; but there is one step before that, to enable landlords to do it. MOST OF US ARE TENANTS FOR IIFE in this country."-Evidence of T. S. Lindsay, Esq., land proprietor, before Devon Commission. 486. Q. 287.

"Estates through Ireland generally are so entailed that the immediate occupier cannot, or will not, expend money in the improvement of the cstate."-Arthur Baker, Esq., Solicitor and Agent. 1068. Q. 25. 
evil of Ireland. For the latter, the act of last session of Parliament will probably be found a sufficient remedy, and public opinion is gradually gaining strength for the cure of the former. Still we must endeavour, in the mean time, to alleviate her condition as much as possible, by the remedies which are within our reach. And if public loans can be justified at all, there are the strongest grounds for their application to Ireland. Nor can they ever be applied to any private object more generally beneficial than the improvement of land; thereby at once providing employment for the people, and increasing the annual produce of the country.

Having thus brought to a close my observations on the state of the West of Ireland, I cannot conclude without expressing an earnest hope that a happier understanding between all classes in that country, based on a juster perception, and a more conscientious fulfilment of their respective duties, may soon form a moral power, stronger for the future preservation of order than the 50,000 armed men whose presence is now found necessary to maintain it. 


$$
3 x^{2}+1+2
$$

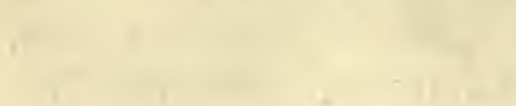

$$
\text { (n) }
$$
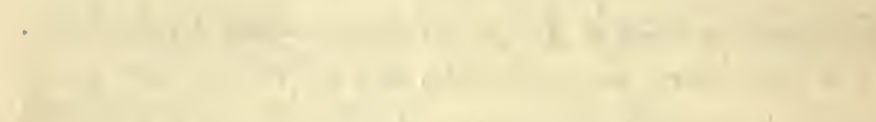

(10)
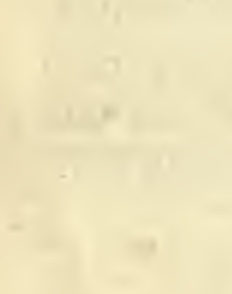

$-3$ 


\section{A P P E N D I X.}

\section{No. I.}

As an instance of what can be done by an Irish farmer, I here give the particulars, ascertained by myself on the spot, of the farm of Mr Boyd of Castle William, on the estate of Lord Londonderry, about seven miles S.E. of Belfast. He has 60 Irish acres, (94 English,) land of fair quality, red gravelly soil, partly but not thoroughly drained. The dwelling-house is much larger than in Scotland would be thought necessary for the extent of the farm. The steading includes a dairy of two apartments, floored with tiles, fitted with horse-churn, stove, and thermometer ; pig-houses ; cow-houses forforty-seven cows; barn over the cow-houses, with horse threshing-mill and straw-cutter attached; stable for seven horses. The dung court is at a lower level than the cattle-houses, the liquid from which flows over the dung. Moss is carted from a considerable distance to mix with the dung, and great attention is paid to increasing and accumulating this valuable substance. The farm is managed in a four-course rotation. But as a great stock is kept on this small farm, principally by house-feeding and cultivating green crops, it may be worth while to note particularly the system followed by Mr Boyd.

8 acres are kept in permanent pasture near the cow-houses, on which the cows are turned out daily for exercise and water.

1. 13 acres are in wheat, 9 of which are sown out with Italian ryegrass ; 4 after the wheat is cut with winter vetches.

2. 13,-9 in Italian rye-grass, cut for soiling, and watered with liquid manure after each cutting; 4 in winter vetches; after which, white turnips.

3. $13,-9$ acres after Italian rye-grass are sown with oats ; 4 with rape, after the turnips are taken up.

4. 13 acres. One half of this is planted with early potatoes"cruffles;" and immediately after they are raised, the ground is filled up with transplanted swedes. The other half of the ground is partly sown with swedes, and partly with mangold and beans. 
Of these 60 acres there are thus annually 13 in wheat, 9 in oats, and 2 in beans-or 24 in grain crops altogether ; 9 in Italian ryegrass, 4 winter vetches, 4 white turnips, 4 in rape, 6 in early potatoes, 7 in swedes, 1 in mangold, and 8 in permanent grass-or 43 acres in green crops and grass ; 7 acres thus bearing a double crop in the year.

The stock kept on this farm were 46 milk-cows, mostly large half-bred stock; a few pigs, and 7 horses; but the horses also do the work of a 40 -acre farm about a mile distant. Mr Boyd has besides a 20 -acre farm in pasture, and on these two adjoining farms he keeps the young stock and such cows as are not giving milk. On the 60-acre farm there is constantly kept a stock of 46 milk-cows. A considerable quantity of distillery draff is purchased to aid in feeding; and by top-dressing the Italian ryegrass in spring with guano, and subsequent liquid applications, three heavy cuts have been obtained. The farm is very well managed, though all the crops might be greatly heavier by an increased application of manure. Of this $\mathrm{Mr}$ Boyd is fully sensible ; and his intention is to go on progressively, not content with what he has yet done.

\section{No. II. \\ POOR LA W.}

EXPENDITURE for Year ended 29th September 1849, in the Unions in the four Counties of Limerick, Galway, Clare, Mayo.

N.B.-It is to be observed that Unions and Counties are not coterminous; but, generally, what is included of other Counties-in Mayo Unions for instance-is balanced by the portions of Mayo included in the Unions of other Connties.

\section{County Limerick-}

\begin{tabular}{rlrr} 
Population. & & Expenditure. & \multicolumn{1}{c}{ Valuation. } \\
75,687 & Kilmallock, & $£ 32,233$ & $£ 177,934$ \\
132,067 & Limerick, & 44,939 & 203,022 \\
60,007 & Newcastle, & 40,536 & 96,148 \\
68,174 & Rathkeale, & 30,730 & 120,806 \\
\hline 335,935 & & $\underline{£ 148,438}$ & $\underline{£}$ \\
\hline
\end{tabular}


County Galway-

Population.

99,026

33,465

88,973

43,543

71,774

$74,974^{\circ}$

$\overline{411,755}$

Ballinasloe,
Clifden,
Galway,
Gort,
Loughrea,
Tuam,

Expenditure.

$£ 25,790$

21,277

36,702

20,996

25,824

32,006

$\overline{£ 162,595}$
Valuation.

$£ 152,167$

19,986

90,903

46,514

91,267

84,573

$£ 485,410$

\section{County Clare-}

$\begin{array}{ll}77,840 & \text { Ennis, } \\ 49,935 & \text { Ennistymon, } \\ 82,353 & \text { Kilrush, } \\ 53,563 & \text { Scariff, }\end{array}$

263,691

County Mayo-

\begin{aligned} & 120,787 Ballina, \\ & 85,031 Ballinrobe, \\ & 61,063 Castlebar, \\ & 73,529 Swineford, \\ & 77,952 Westport, \\ & \hline\end{aligned}

418,302

\begin{tabular}{|c|c|}
\hline$£ 46,551$ & $\mathfrak{E} 100,238$ \\
\hline 38,503 & 63,793 \\
\hline 39,338 & 59,247 \\
\hline 34,595 & 55,274 \\
\hline$£ 158,987$ & $£ 278,552$ \\
\hline
\end{tabular}

\begin{tabular}{rr}
$£ 54,231$ & $£ 89,151$ \\
35,779 & 85,216 \\
31,068 & 49,988 \\
19,846 & 46,164 \\
28,361 & 39,019 \\
\hline$£ 169,285$ & $£ 309,538$
\end{tabular}

\section{No. III.}

ANSWERS to INQUiRIEs made in the Months of JuLY and AUGUST 1849, as to the expediency of affording Assistance for the Emigration of Destitute Persons in the Distressed Unions, (in the Counties of Limerick, Clare, Mayo, and Galway,) who would otherwise be dependent on the poor-rates.

\section{LiMERICK.}

There are thousands of young unmarried women, (say between 18 and 25,) in this and the adjoining counties, who would gladly emigrate, there being little or no employment for them, and many being consequently compelled to enter the workhouse and remain there. For this class especially, such a measure would be most desirable. 


\section{Clare, (central part.)}

Agricultural labourers with families, and families deserted by husbands and fathers who have emigrated, might advantageously be enabled to emigrate. In some of the communications from other districts, sending out deserted families is objected to, as affording encouragement to desertion.

\section{Clare, (west coast.)}

Although the population would not be too great if the land were properly cultivated, there are many who must either be enabled to emigrate, or be permanently chargeable to the Union.

\section{Claare, (south-west.)}

The great majority of the destitute class here are so extremely ignorant and helpless as to be unfit for emigration; but there are many intelligent ones who could do well in the colonies, but must here be permanently chargeable.

5. Clare, (east,) and adjoining part of Galway.

There are many able-bodied men with large families, as well as young unmarried persons of both sexes, who, being unable to obtain employment, are a burden here, and whose emigration, especially that of the latter class, would afford permanent relief.

6. Galway, (south.)

The largest class dependent on the poor-rates here consists of able-bodied unmarried women. These, and men with large families, who can never support themselves at the present rate of wages, might advantageously be sent out, but not unmarried men, nor men with small families.

7. Galway, (vicinity of Galway town, and part of Connemara.)

The largest and most increasing class of paupers here also is that of able-bodied unmarried women, farm-servants unemployed in consequence of the distress, but well fitted for the labour of colonial life. There are also many able-bodied men who are unable to support themselves, and are not likely to be wanted for a considerable time. 
8. Galway, (extreme west.)

Unmarried females are the only class here whom it is desirable to remove : of these there are great numbers destitute, and who would gladly go.

9. Galway, (north.)

The same class (destitute unmarried females) exists here in large numbers, from the discontinuance of employment of farm-servants, and must be a permanent burden unless enabled to emigrate.

10. Galway, (west,) and adjoining part of Mayo.

The same class, and that of young single men, but the latter not in so great number as the former, fill the workhouses here, and their removal would be a permanent benefit.

11. MaYo, (south.)

Single men and women, especially the latter, and widows without children, under the age of 25 , might be advantageously sent. Farm-servants are now scarcely ever sought.

12. Mayo, (near Westport.)

* $\quad * \quad * \quad * \quad * \quad * \quad * \quad *$

\section{MaYo, (east.)}

There are hundreds of healthy unmarried females, between 15 and 30 , destitute, and who might be relieved by emigration.

14. Mayo, (central.)

Emigration is desirable as an immediate relief, until capital can be introduced and employment provided.

15. Mayo, (north.)

Emigration affords the only hope for the wretched evicted families now in the most miserable hovels. The only objection to this is the fear that evictions might thus be encouraged. 
No. IV.

GRAND-JURY PRESENTMENTS, \&C.

\begin{tabular}{|c|c|c|c|}
\hline Counties. & $\begin{array}{l}\text { Amount of ordinary } \\
\text { Grand-Jury Presentments } \\
\text { granted in } 1849 .\end{array}$ & $\begin{array}{r}\text { Amount of Asses } \\
\text { under Labour-Rat } \\
\text { in } 1849 .\end{array}$ & $\begin{array}{l}\text { sment } \\
\text { e Acts }\end{array}$ \\
\hline Mayo county,..... & $£ 30,229 \quad 11 \quad 10$ & & \\
\hline Clare, ..... & $\begin{array}{lll}53,011 & 13 & 8\end{array}$ & *819 16 & 6 \\
\hline Galway,....... & $29,784 \quad 1 \quad 7$ & 13,138 & 3 \\
\hline Limerick,............ & $54,792 \quad 13 \quad 5$ & $+38,342$ & 3 \\
\hline
\end{tabular}

No. V.

RETURN, up to 20th November, of Labour-Rate and ReliefLoans to Counties of Galway, Mayo, Clare, and Limerick; and the amount paid.

I. LABOUR-RATE LOANS :-

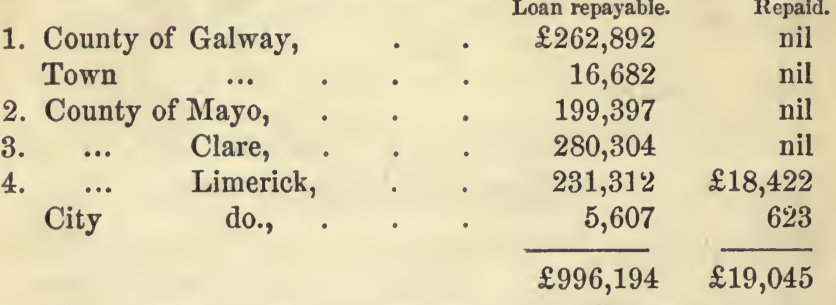

* This sum appears to have been exclusively for damages.

+ This sum is for three halfyearly instalments. 
II. Relief Loans, 10 Vic. c. 7 (Burgoyne's Act.)

\begin{tabular}{|c|c|c|c|c|}
\hline \multicolumn{3}{|l|}{ Unions. } & Loan. & \multirow{3}{*}{$\begin{array}{c}\text { Repaid. } \\
\text { nil }\end{array}$} \\
\hline Ballina, & . & . & $£ 13,716$ & \\
\hline Ballinrobe, & . & . & 12,183 & \\
\hline Castlebar, & . & . & 7,282 & nil \\
\hline Swineford, & . & . & 6,620 & nil \\
\hline Westport, & . & . & 5,624 & nil \\
\hline Clifden, & . & . & 3,228 & nil \\
\hline Ballinasloe, & . & . & 20,346 & nil \\
\hline Gort, . & . & . & 7,663 & nil \\
\hline Galway, & . & . & 14,029 & nil \\
\hline Loughrea, & . & . & 10,295 & nil \\
\hline Tuam, . & $\cdot$ & . & 12,300 & nil \\
\hline Ennis, . & $\cdot$ & . & 14,340 & nil \\
\hline Ennistymon, & . & . & 9,644 & nil \\
\hline Kilrush, & . & . & 8,555 & nil \\
\hline Scariff, & . & . & 6,406 & nil \\
\hline Limerick, & . & . & 25,119 & $£ 2021$ \\
\hline Kilmallock, & . & . & 22,228 & nil \\
\hline Rathkeale, & - & . & 17,857 & nil \\
\hline Newcastle, & . & . & 14,944 & 505 \\
\hline & 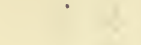 & & 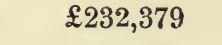 & $£ 2526$ \\
\hline & & & Loans repayable. & Repaid. \\
\hline Labour-rate & oans (to $\mathrm{C}$ & unties), & $£ 996,194$ & $£ 19,045$ \\
\hline Relief Loans & (to Unions & , . & 232,379 & 2,526 \\
\hline & & & $£ 1,228,573$ & $£ 21,571$ \\
\hline
\end{tabular}




\section{No. VI.}

By the Tithe Composition Returns of 1835, the amount of Lay and Clerical Tithe Composition in the under-named Dioceses, which may be taken as comprising the Counties of MaYo, Galway, Clare, and Limerick, appears to have been as follows :-

$$
\begin{aligned}
& \text { Tuam,-Lay, } \quad \text { - } \quad \begin{array}{rrrr} 
& £ 650 & 8 & 5 \frac{1}{2}
\end{array} \\
& \text { " Ecclesiastical, • 18,810 } 15 \quad 6
\end{aligned}
$$

Clonfert and Kilmaiduagh,-Ecclesiastical, $\quad \begin{array}{rrr}8,839 & 0 & 0\end{array}$ Killala,-Lay, • • $£ 1,533145$ " Ecclesiastical, . 6,565 126

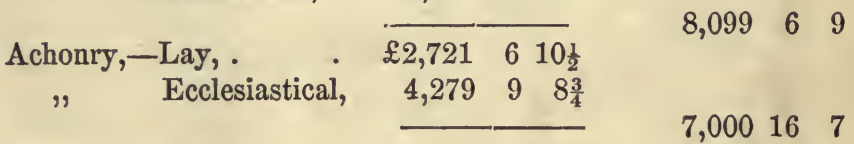

$$
\begin{aligned}
& \text { Emly,-Lay, • • } \$ 2,950 \quad 510 \\
& \text { " Ecclesiastical, . } 7,48018 \quad 0
\end{aligned}
$$

Limerick,-Lay, $\quad$. $\quad £ 5,873 \quad 4 \quad 3$

" Ecclesiastical, $19,42018 \quad 9$

$$
25,294 \quad 3 \quad 0
$$

Killaloe \& Kilfenora,-Lay, $£ 4,483 \quad 9 \quad 8$

$\because \quad$ Ecclesiastical, 24,903 $14 \quad 7$

Total,

$£ 108,51218 \quad 5$

75 per cent on this sum amounts to $£ 81,3841310$

which may therefore be taken as an approximation to the amount of tithe rent-charge in their dioceses.

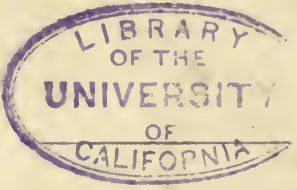


APPENDIX.

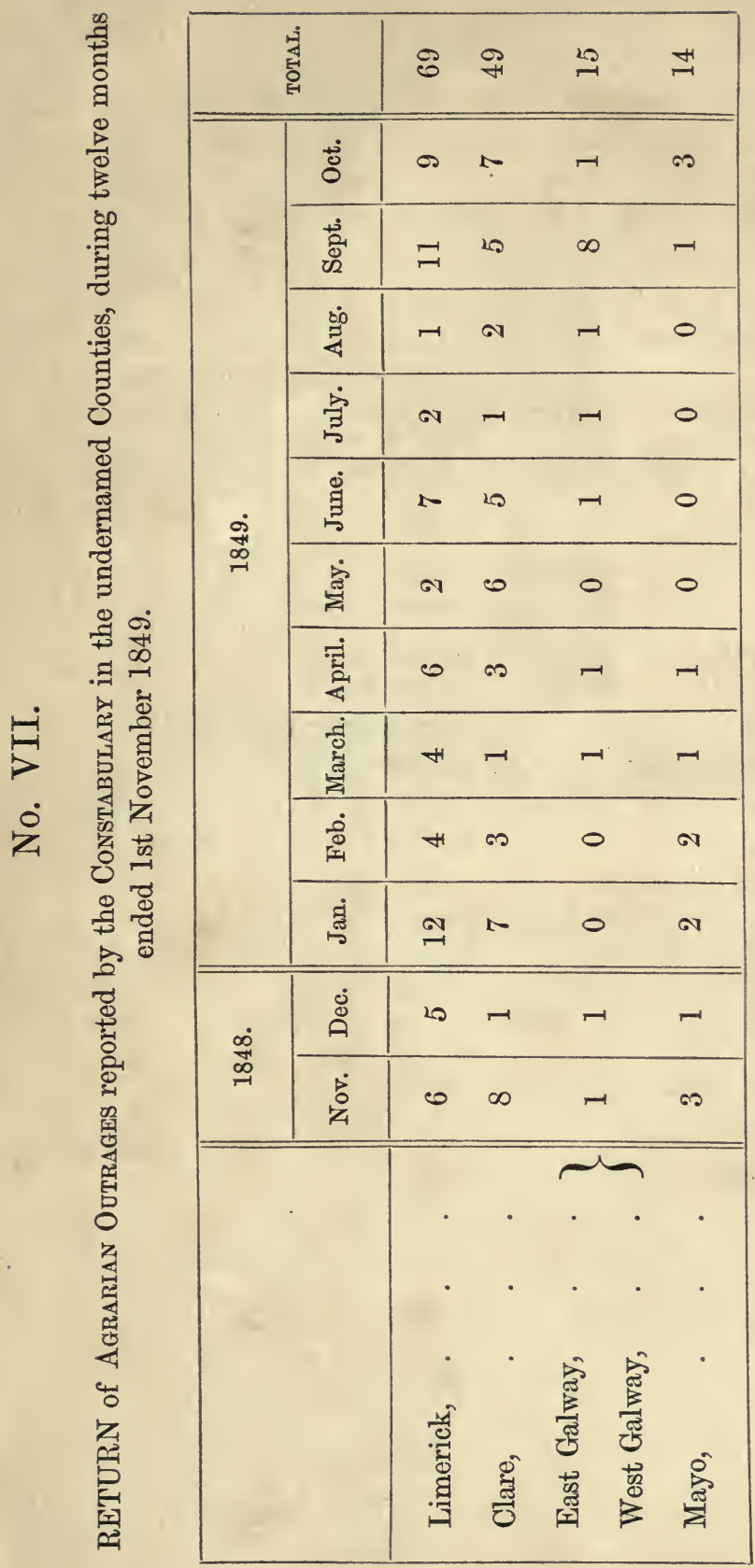


PRINTED BY WILLIAM BLACKWOOD AND SONS, EDINBURGH. 
$=10$

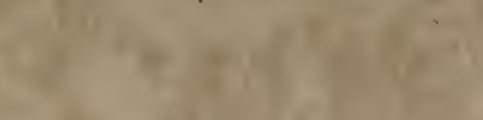

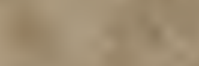

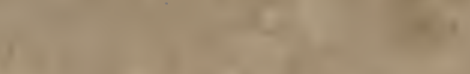

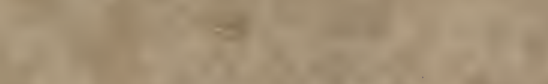

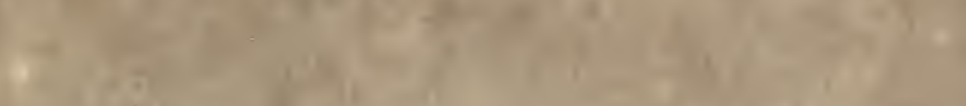

$+4$

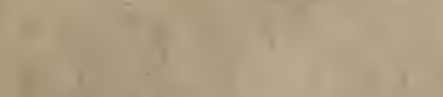

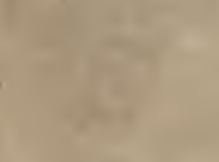

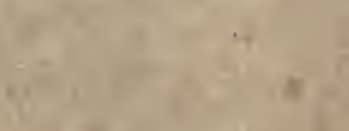

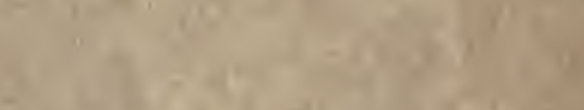

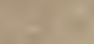

.

$+4$<smiles>C1CCCC1</smiles>

L

$+\cdot$

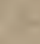

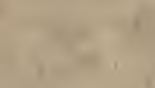

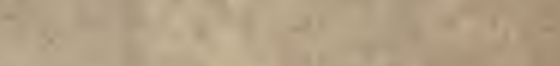

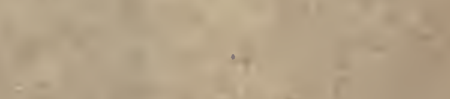

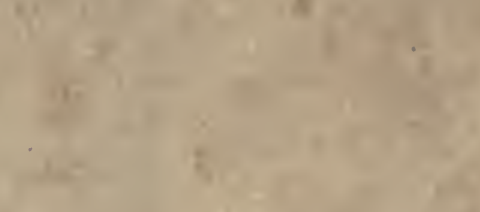

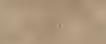

.

s.

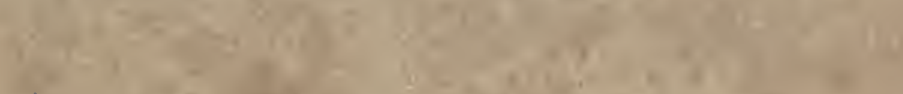

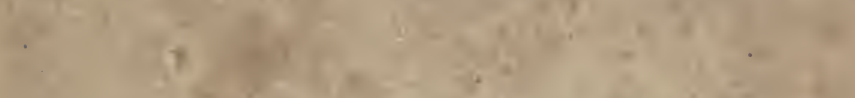

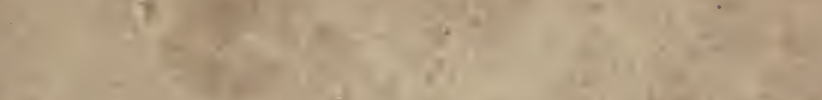

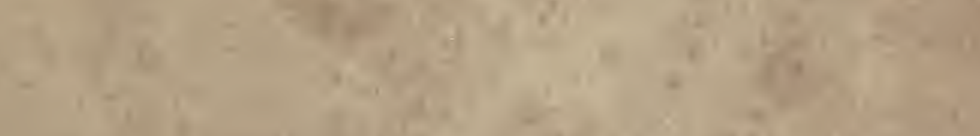

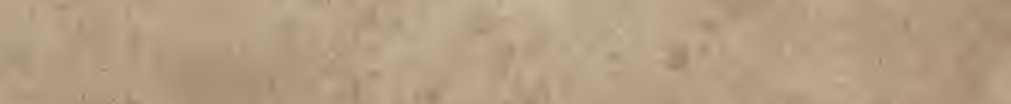

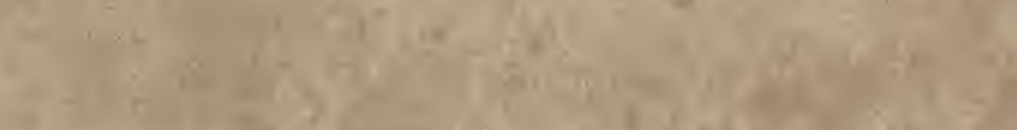

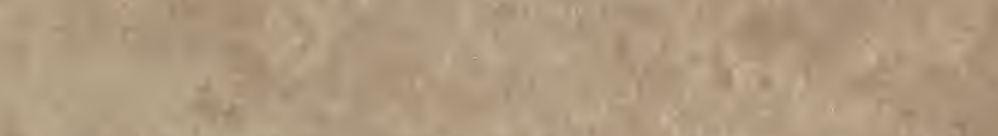

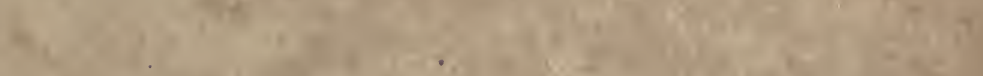

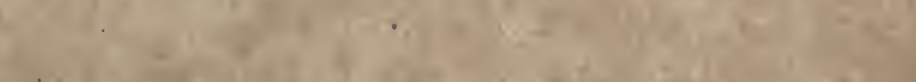

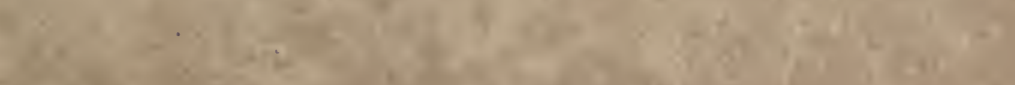

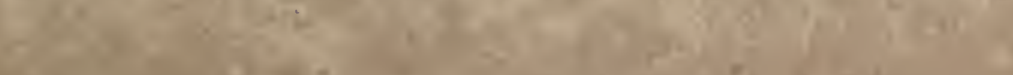

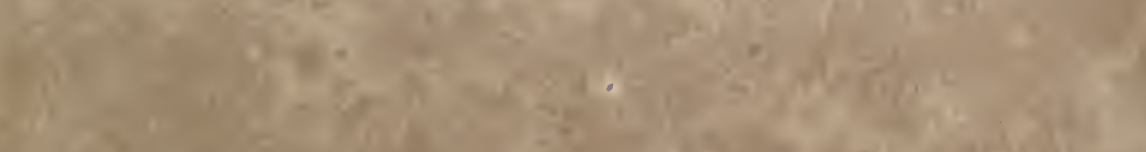

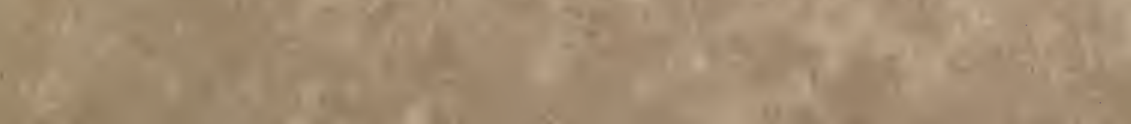




\section{DAY USE}

RETURN TO DESK FROM WHICH BORROWED

This book is due on the last date stamped below, or on the date to which renewed.

Renewed books are subject to immediate recall.

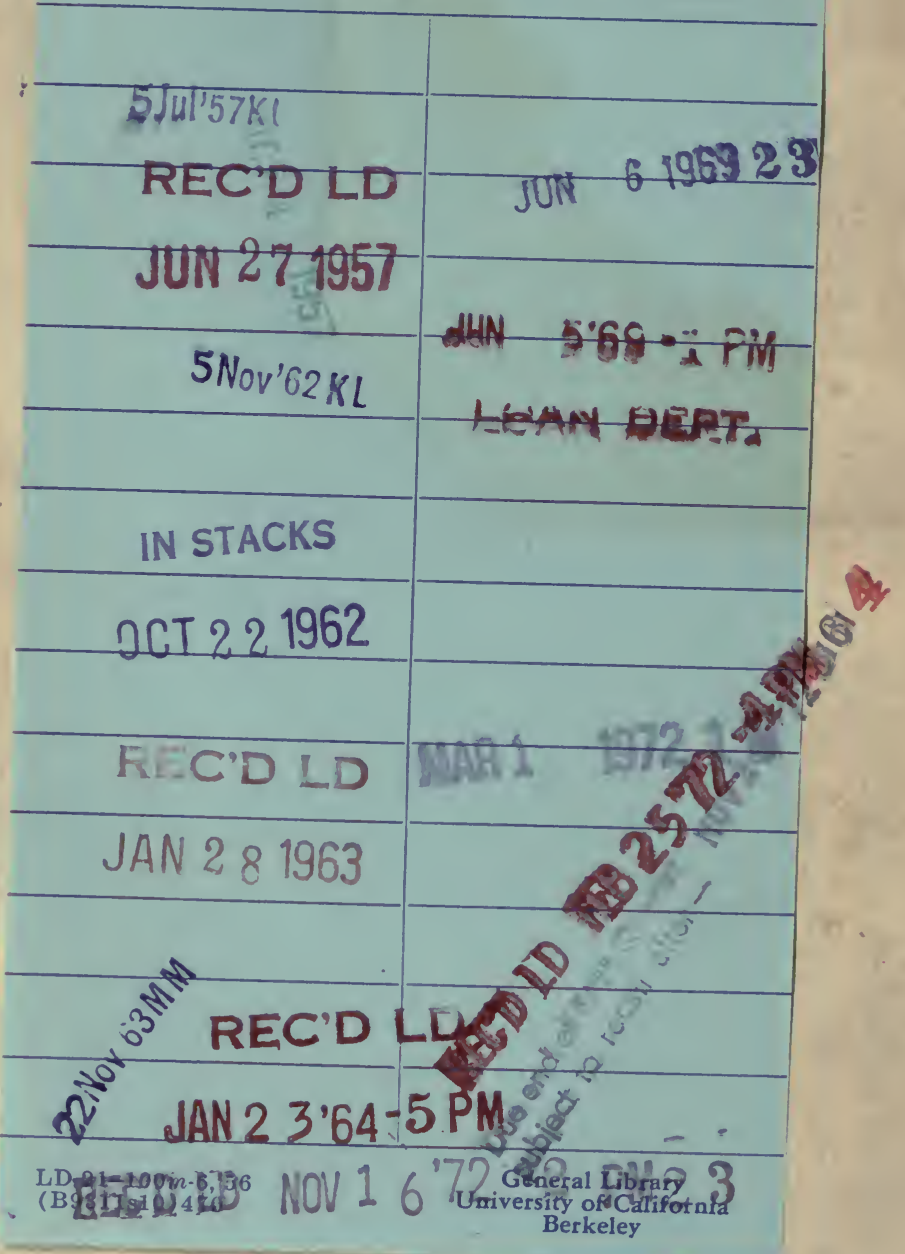


